\title{
PAST - PRESENT - FUTURE: THE REVITALIZATION OF SOCIAL HOUSING IN CANADA
}

by

\author{
Johann Sinclair Atterbury \\ Bachelor of Arts in Architecture, \\ University of Technology, Jamaica, 2002
}

A design thesis/project

presented to Ryerson University

in partial fulfillment of the

requirements for the degree of

Master of Architecture

Toronto, Ontario, Canada, 2009

(C) (Johann S. Atterbury) 2009 
I hereby declare that I am the sole author of this thesis Iproject. I authorize Ryerson University to lend this thesis/project to other institutions or individuals for the purpose of scholarly research.

Johann S. Atterbüy

I further authorize Ryerson University to reproduce this thesis / project by photocopying or by other means, in total or in part, at the request of other institutions or individuals for the purpose of scholarly research.

Joharh S. Atterbury

Past - Present - Future: The Revitalization of Social Housing in Canada 


\section{Abstract}

Past - Present - Future : The Revitalization of Social Housing in Canada

M.Arch. 2009 I Johann Sinclair Atterbury I Master of Architecture I Ryerson University

There is an urgent need to provide, maintain and revitalize social housing in Canada. Statistics show that an alarming percentage of Toronto's population lives in poverty. 71,000 families are currently on the social-housing waiting list and 150,000 to 300,000 Canadians are homeless.

This research provides a critical analysis of the past and existing issues surrounding the design and function of social housing communities. In response to the issues outlined, this study identifies a need for the design of mixed-activity, 'integrated neighbourhoods' rather than isolated social housing schemes. The thesis proposes an architectural solution that draws on five guiding principles (modes of integration) of design. Integration of movement, open spaces, physical structures, social integration, and integrated sustainable systems were the five categories used to examine the level of intervention necessary for the revitalization of a selected site; Alexandra Park, Toronto, Canada. 


\section{Acknowledgements}

First and foremost, praise to God for making all things possible and blessing me with the ability to complete this project in pursuit of higher education. Much love to my brother and sister (Kris and Kerri) for their prayers and words of encouragement when I needed them most.

Appreciation and special thanks to my supervisor, Dr. Joseph Springer, first for taking on the role of advising me throughout this daunting process and, second, for his guidance, knowledge and patience along the way. While he has taught me a great deal about the issues of social housing, Dr. Springer has also subconsciously broadened my understanding of what research is and how it should be conducted at varying stages of a project. For the opportunity to have rigorous discussions regarding social issues, in which we share a common deep interest, I am truly grateful.

Many thanks to Harold Madi for agreeing to be my external examiner and guiding me through the various stages of my architectural design development. Thanks, as well, to Sam Davis and Ed Majchrowski, who took the time to share their knowledge and opinions on specific issues of housing and social need.

I'm grateful to Toronto Community Housing Corporation (TCHC), Canada's largest social-housing provider, for welcoming me to one of its many tenant-engagement meetings, which allowed me to gain an understanding of some of the issues that arise when dealing with social-housing tenants. Thanks to Colin Ripley for his general feedback and the instilment of critical thinking within me and my fellow classmates.

Past - Present - Future: The Revitalization of Social Housing in Canada 
To my dearest parents; Rose-Ann Gopaulsingh-Atterbury and Karl Sinclair Atterbury. Gone, but you will never be forgotten. To my bro and sis; Kris and Kerri Atterbury; Blessingz Alwayz. 


\section{Table of Contents}

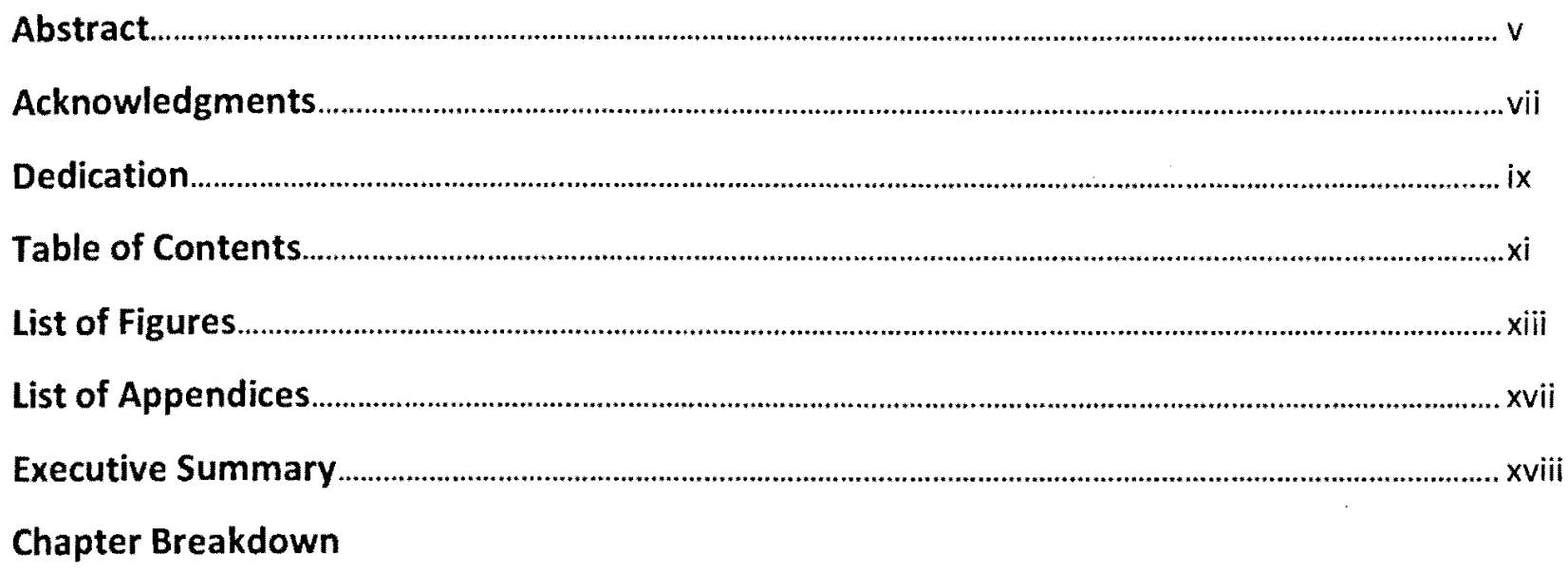

(1) Introduction

\section{( 2 ) Literature Review}

Overview.

Social Housing in Canada: Acknowledging the Complexities

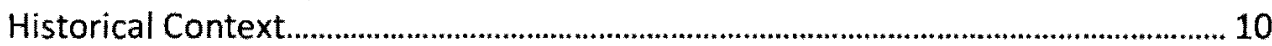

The Federal, Provincial, \& Municipal Role............................................................... 16

The Emergence of a Governing Social Housing Provider......................................... 18

Existing Remediation Proposals................................................................................. 21

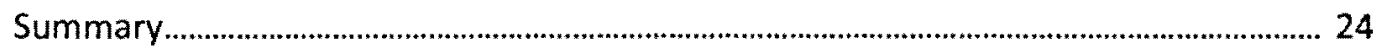

\section{(3) Research Methodology}

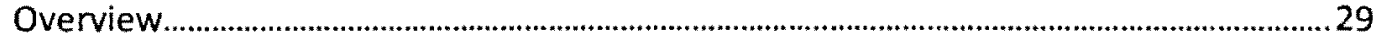

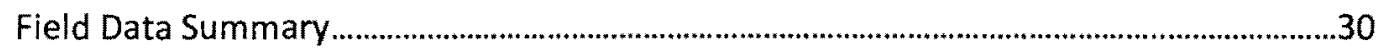

Regent Park, Pruitt Igoe, Cabrini Green: Why early design

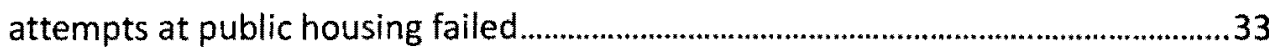

Case Studies: A Precedent Review of Existing Alternatives

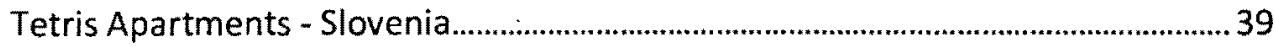

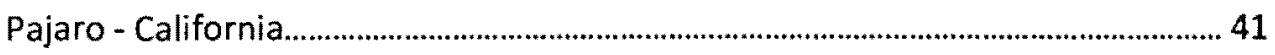

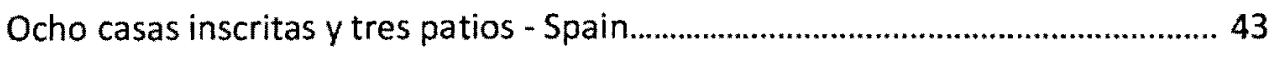

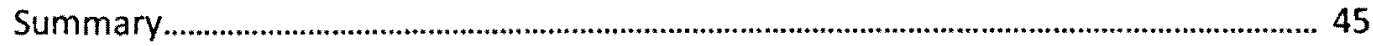

Past - Present - Future: The Revitalization of Social Housing in Canada

$\begin{array}{ccc}\text { thesis student: } & \text { thesis supervisor: } & \text { date: } \\ \text { Johann Atterbury } & \text { J Joseph Springer } & \text { I 25-September-2009 }\end{array}$




\section{(4) Design Project}

Integration: A Mandate to Reform Social Housing Design ......................................................49

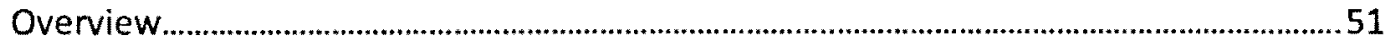

Alexandra Park - Site Location \& Analysis .............................................................................. 53

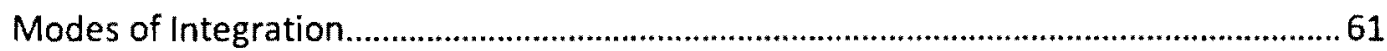

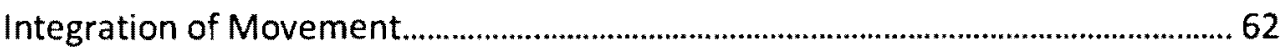

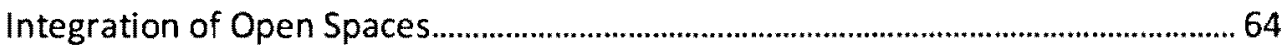

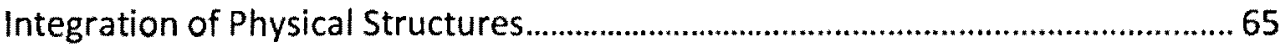

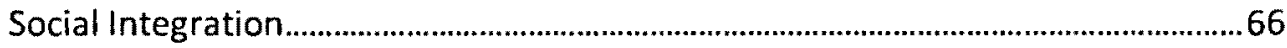

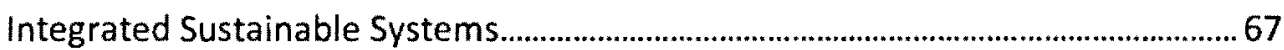

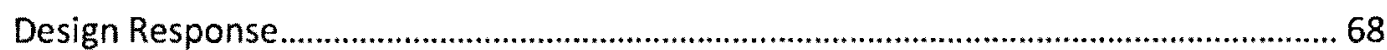

Integrated System Type 'A'

Integrated System Type 'B' ........................................................................................... 81

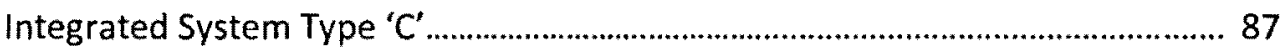

Alexandra Park - Comparative Data Analysis................................................................. 92

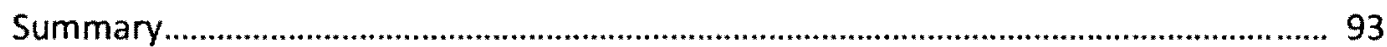

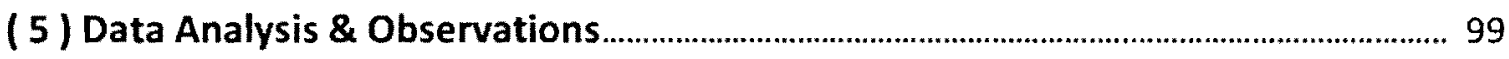

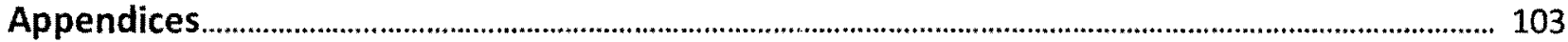

References.

Glossary of Terms

Past - Present - Future: The Revitalization of Social Housing in Canada

thesis student: thesis supervisor: date: 


\section{List of Figures}

Figure i: Conceptual Framework of Canadian Social Housing Policy. (1946 - Present)...................... $x$

Figure ii: $\quad$ Future Conceptual Framework of Canadian Social Housing Policy......................................... xi

Figure 1.00: Conceptual Framework of Canadian Social Housing Policy (1946 - Present........................ 4

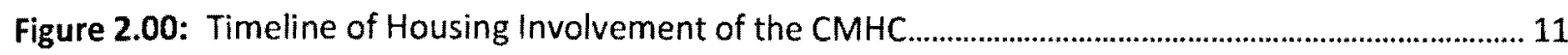

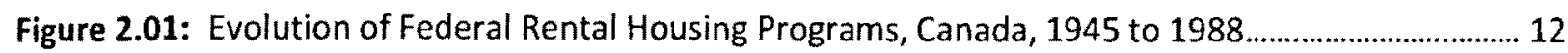

Figure 2.02: Percentage of families and individuals below the low income cut-off................................. 13

Figure 2.03: Vacancy Rates of Toronto Community Housing Corporation (TCHC) for 2005................. 15

Figure 2.04: Government-assisted housing production, City of Toronto, 1984 to 2010......................... 17

Figure 2.05: Toronto Community Housing's 2007 Financial summary ..................................................... 19

Figure 2.06: Chronology of modern apartments in Toronto ................................................................ 21

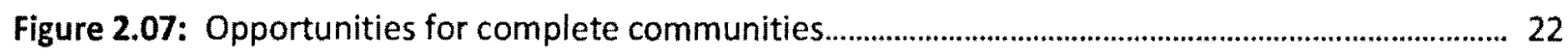

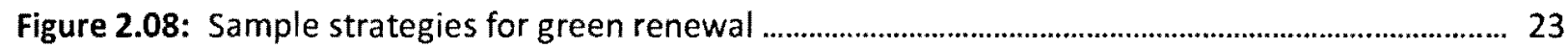

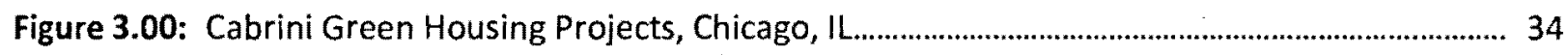

Figure 3.01: Regent Park Housing Development, Toronto, ON................................................................ 34

Figure 3.02: Pruitt-Igoe Housing Development, St. Louis........................................................................ 34

Figure 3.03: Regent Park North, Building Layout, 1950............................................................................... 35

Figure 3.04: Regent Park North: Problems Related to Existing Open Space..............................................36

Figure 3.05: Regent Park Revitalization Plan (Aerial View) ............................................................................ 37

Figure 3.06: Regent Park Revitalization Plan............................................................................................ 38

Figure 3.07: Regent Park Revitalization Plan (One Cole Garden) ................................................................. 38

Figure 3.08: Regent Park Revitalization Plan (One Oak Street) .................................................................. 38

Figure 3.09: Regent Park Revitalization Plan (Townhouses).......................................................................... 38

Figure 3.10: Tetris Apartments (Perspective View) …................................................................................... 39

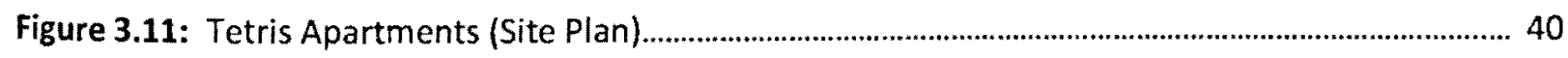

Figure 3.12: Tetris Apartments (North Elevation) ............................................................................................. 40

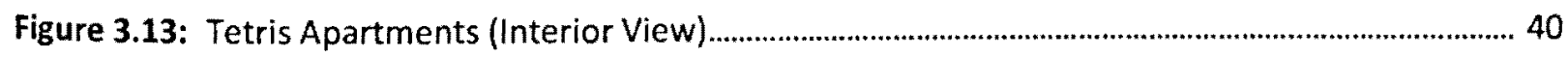

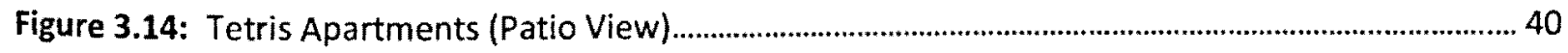

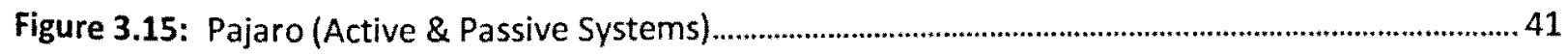

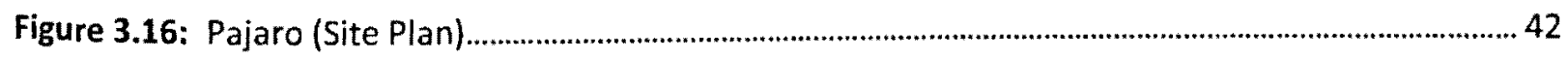

Past - Present - Future: The Revitalization of Social Housing in Canada

thesis student:
ohann Atterbury I Joseph Springer I 25-September-2009 
Figure 3.17: Pajaro (Perspective View)

Figure 3.18: Pajaro (Permutations).

Figure 3.19: Ocho casas inscritas y tres patios (Façade Permutations)..

Figure 3.20: Ocho casas inscritas $y$ tres patios (First Floor Plan) ................................................................ 44

Figure 3.21: Ocho casas inscritas y tres patios (Lightwell)............................................................................... 44

Figure 3.22: Ocho casas inscritas y tres patios (Building Facade) ..................................................................4

Figure 3.23: Present-day elements of social housing design.......................................................................... 45

Figure 4.00: Elements characteristic of integrated neighbourhoods........................................................... 49

Figure 4.01: Modes of Integration............................................................................................................... 52

Figure 4.02: Site Location - Alexandra Park, Toronto, Canada................................................................ 53

Figure 4.03: Alexandra Park - Existing Site Data.................................................................................... 53

Figure 4.04: Aerial View - Alexandra Park, Toronto, Canada...................................................................... 53

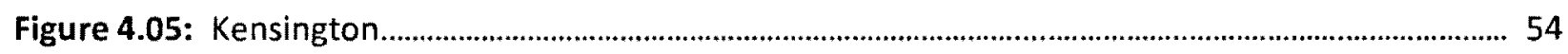

Figure 4.06: Alexandra Park....................................................................................................................... 54

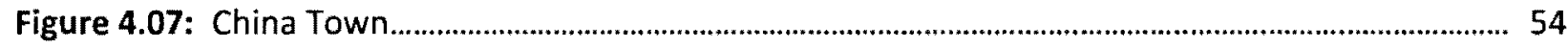

Figure 4.08: Trinity Bellwoods................................................................................................................ 54

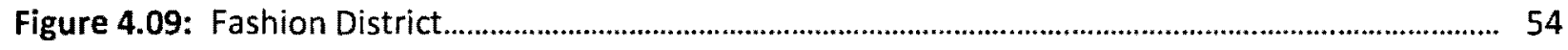

Figure 4.10: Neighbourhoods surrounding Alexandra Park.......................................................................... 54

Figure 4.11: Statistical Data......................................................................................................................... 54

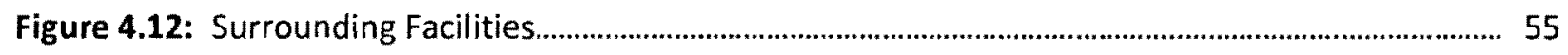

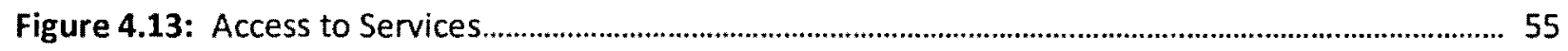

Figure 4.14: Existing Site Layout \& Key Map............................................................................................... 57

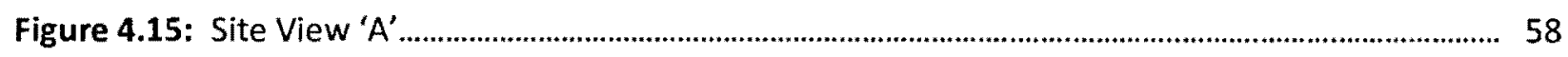

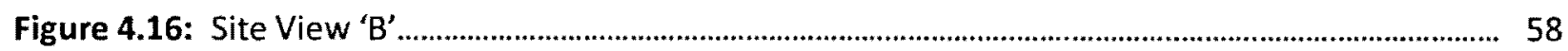

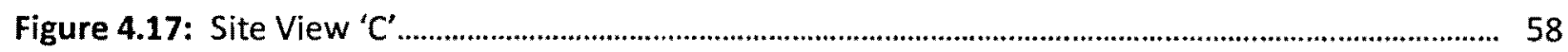

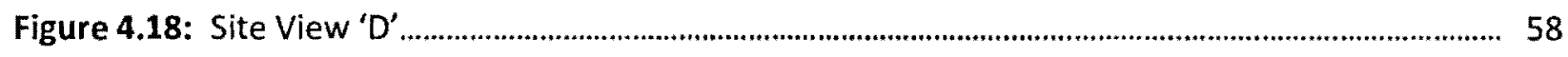

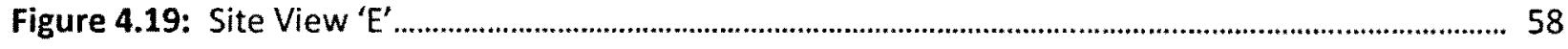

Figure 4.20: Site View 'F'

Figure 4.21: Site View 'G'

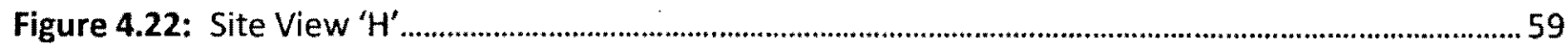

Past - Present - Future: The Revitalization of Social Housing in Canada 


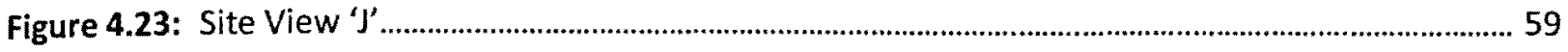

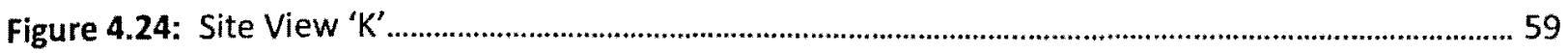

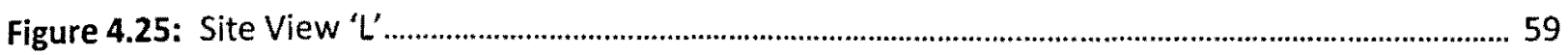

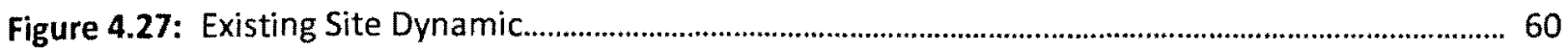

Figure 4.28: Alexandra Park - area before the 1966 redevelopment ...................................................... 62

Figure 4.29: Alexandra Park - Augusta Avenue after the 1966 redevelopment...................................... 62

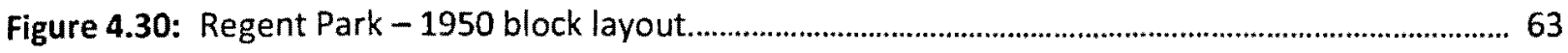

Figure 4.31: Alexandra Park - present block layout.................................................................................63

Figure 4.32: Regent Park figure ground: 1950 and present layouts....................................................... 63

Figure 4.33: Alexandra Park figure ground: present and proposed layouts...............................................63

Figure 4.34: Alexandra Park - existing layout along Grange Avenue .......................................................

Figure 4.35: Alexandra Park - proposed layout along Grange Avenue................................................... 63

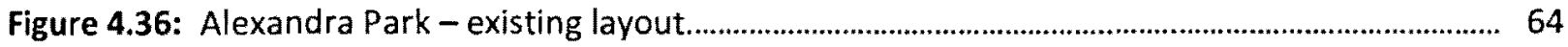

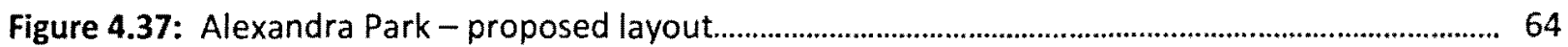

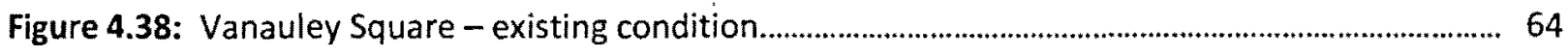

Figure 4.39: Vanauley Square - proposed condition ......................................................................................... 64

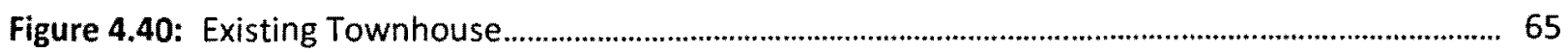

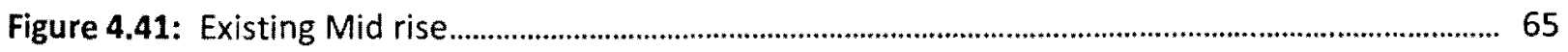

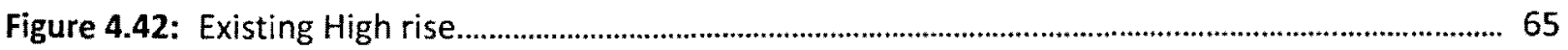

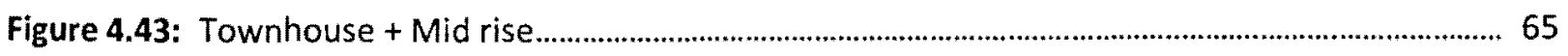

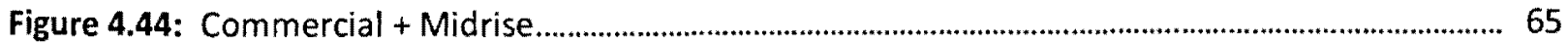

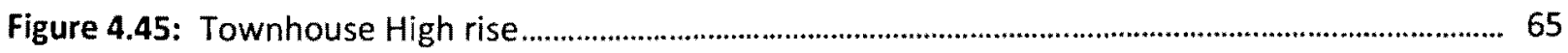

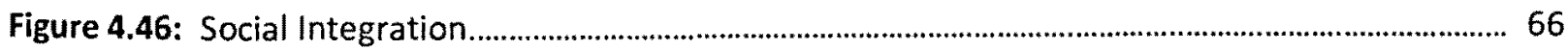

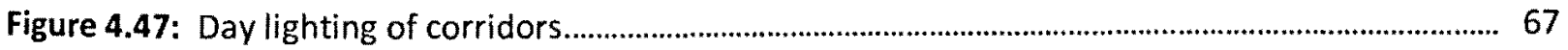

Figure 4.48: Existing Site Layout \& Key Map.............................................................................................. 70

Figure 4.49: Proposed Site Layout \& Key Map................................................................................................... 71

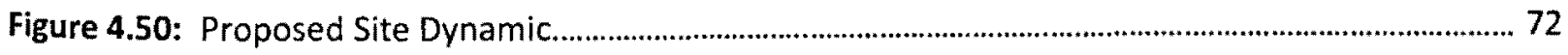

Figure 4.51: Existing Site View 'A'

Figure 4.52: Proposed Site View 'A'

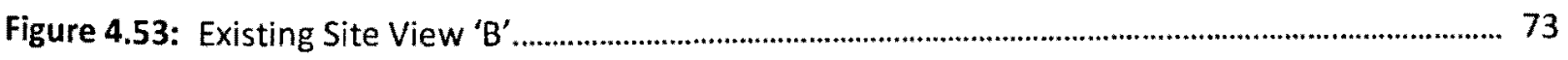

Past - Present - Future: The Revitalization of Social Housing in Canada 
Figure 4.54: Proposed Site View ' $B$ '

Figure 4.55: Existing Site View ' $C$ '.

Figure 4.56: Proposed Site View ' $C$ '

Figure 4.57: Parti Composition (Integrated System Type 'A')

Figure 4.58: Part Site Plan ' $A$ ' 76

Figure 4.59: Parti Assembly (Integrated System Type ' $A$ ') 77

Figure 4.60: Schematic Section (Integrated System Type ' $A$ ') 77

Figure 4.61: Schematic Layout (Integrated System Type 'A'). 78

Figure 4.62: Permutations (Integrated System Type ' $A$ ') 78

Figure 4.63: Floor Plans (Integrated System Type 'A') 79

Figure 4.64: Perspective View ' $A$ '. 80

Figure 4.65: Integrated System Type 'A' Elevations. 80

Figure 4.66: Perspective View ' $B$ ', 80

Figure 4.67: Parti Composition (Integrated System Type 'B'). 82

Figure 4.68: Part Site Plan ' $B$ ' 82

Figure 4.69: Parti Assembly (Integrated System Type 'B'). 83

Figure 4.70: Schematic Section (Integrated System Type 'B') 83

Figure 4.71: Floor Plans (Integrated System Type ' $\mathrm{B}$ ') 84

Figure 4.72: Perspective View ' $C$ '. 85

Figure 4.73: Integrated System Type 'B' Elevations. 85

Figure 4.74: Perspective View ' $D$ '. 85

Figure 4.75: Parti Composition (Integrated System Type ' $C$ ') 88

Figure 4.76: Part Site Plan ' $C$ '. 88

Figure 4.77: Schematic Section (Integrated System Type ' $C$ ') ............................................................. 89

Figure 4.78: Floor Plans (Integrated System Type ' $C$ ') ............................................................................ 90

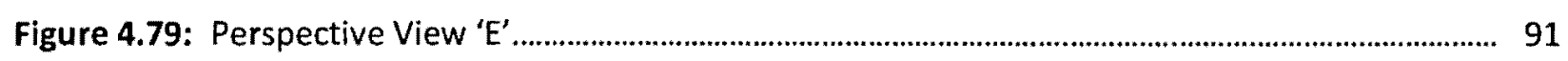

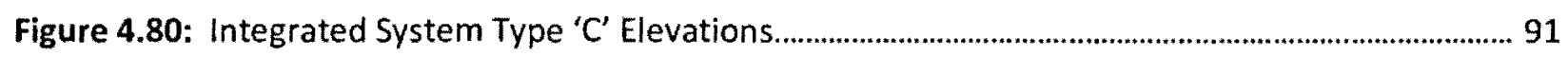

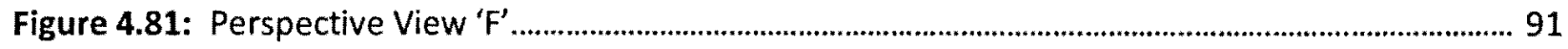

Figure 4.82: Alexandra Park - Comparative Site Data.............................................................................. 93

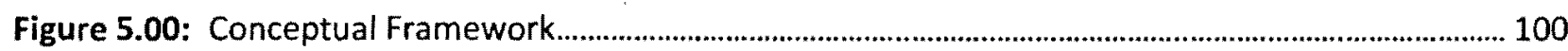

Past - Present - Future: The Revitalization of Social Housing in Canada 


\section{List of Appendices}

Appendix A Field Data Collection:

Toronto Community Housing: Tenant Engagement Meeting................................... 103

Interview - Ed Majchrowski - Toronto Community Housing.....................................108

Interview - Sam Davis - Affordable Housing Architect................................................. 109

Past - Present - Future: The Revitalization of Social Housing in Canada 


\section{Executive Summary}

There is an urgent need to provide, maintain and revitalize social housing in Canada. Statistics show the following alarming facts:

- 552,300 people, or a quarter of Toronto's population, live in poverty,

- 720,000 Canadians had to make use of food banks in 2002,

- 71,000 families are currently on the (social-housing) waiting list (2008),

- 150,000 to 300,000 Canadians are homeless,

- 31,985 people stayed in Toronto's emergency shelters in 2002,

- More than 250,000 tenant households pay more than 30 per cent of their income on rent; 20 percent pay more than 50 percent, and

- More than 25 percent of tenants in Toronto have annual incomes below $\$ 20,000$.

This current state is largely attributable to the fact that the federal government downloaded its responsibilities in 1993, followed shortly thereafter by the provincial, through its Local Services Realignment, in 1998. Funding became a major issue causing new construction to cease (and never recover), and the existing social-housing stock continues to deteriorate (see figure i).

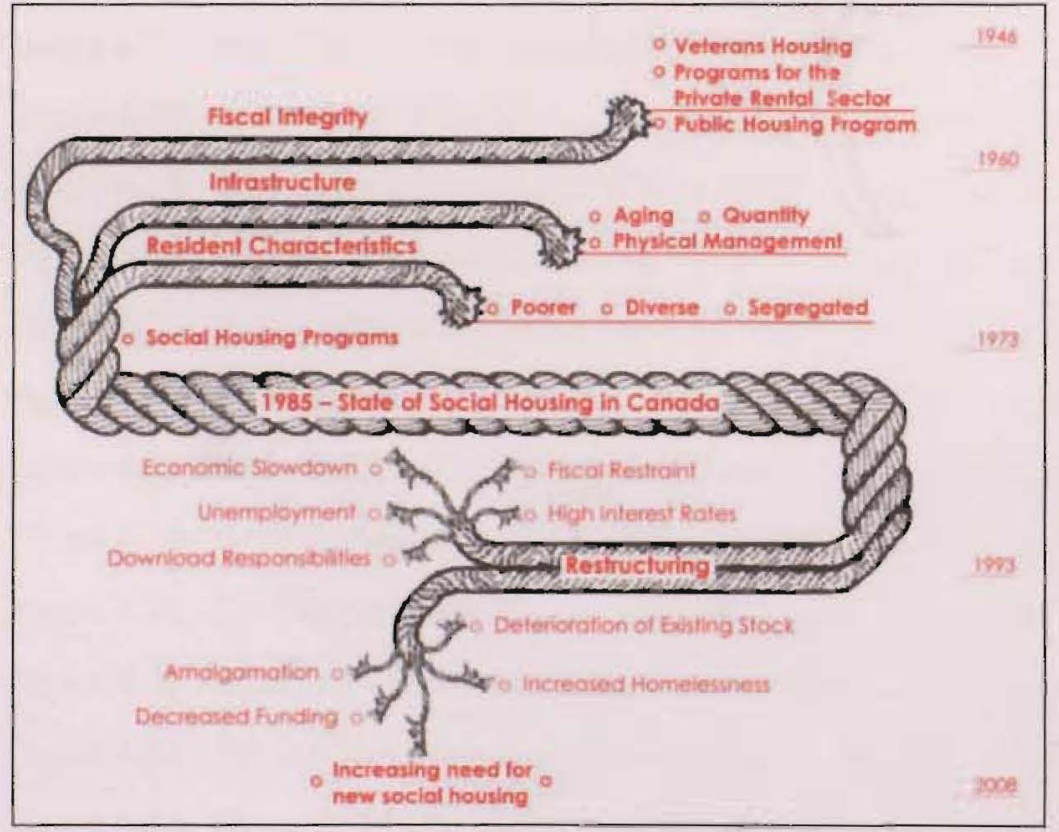

Figure i. Conceptual Framework of Canadian Social Housing Policy.

(1946 - Present)
Figure i proposes a graphical

framework highlighting some of the critical (policy driven) events which contributed to the present state of social housing in Canada. With reduced federal \& provincial funding and an aging \& deteriorating portfolio, all areas point to an urgent need to remediate and increase the social housing stock.

\section{EXISTING-CONDITION}


The vision for public housing of the 1950s and 1960s, which was heavily inspired by Corbusier's Radiant City, proved to be a global disaster as it resulted in:

- High-rise apartments built as a mere reflection of the building code, with no real connection to the street and its surrounding environment,

- Durable concrete structures but with inexpensive interiors and the lack of maintenance led to high levels of deterioration and inefficiency.

The combination of high concentrations of low-income individuals and the minimal levels of initial quality of construction speedily led to slum creation, and removed the hope that individuals might be inspired by positive role models. The resulting social and physical deterioration brought about the eventual demolition of several public housing buildings around the world, and a new style of social housing emerged:

With a combination of low-, mid-, and high-rise structures,

- Mixed-use and mixed-income developments, such as non-profits and co-ops.

This research provides a critical analysis of the past and existing issues surrounding the design and function of social housing communities. In response to the issues outlined, this study identifies a need for the design of mixed-activity, 'integrated neighbourhoods' rather than isolated social housing schemes. The thesis proposes an architectural solution which draws upon five guiding principles (modes of integration) for design. Integration of movement, open spaces, physical structures, social integration, and integrated sustainable systems were the five elements used to examine the level of intervention necessary for the revitalization of a selected site; Alexandra Park, Toronto, Canada.

\footnotetext{
The figure (right) proposes the positive impact of architectural intervention on Canadian Social Housing Policy. With federal and provincial funding as a catalyst, sustainable, community driven designs can be applied to both new and existing stock with greater levels of architectural involvement.

PROPOSED - INTERVENTION
}

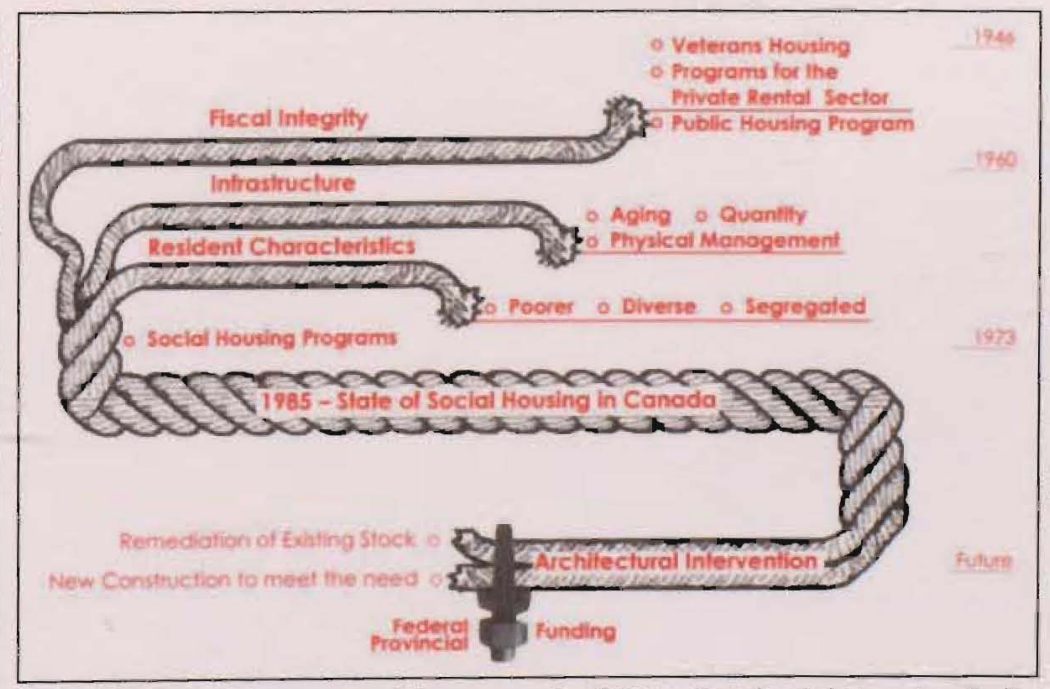

Figure ii. Future Conceptual Framework of Canadian Social Housing Policy. 


\section{Introduction}

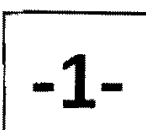

"There is no social-change fairy. There is only the change made by the hands of individuals."

Winona LaDuke 
The Housing Crisis: A comparative investigation of the past, current, and future social-housing systems in Brazil, Canada, and Jamaica.

With my (tentative) thesis topic established, I was set to embark upon a rigorous comparison of social-housing systems in selected urban areas of Brazil, Canada, and Jamaica, and to begin to establish what each country could gain from the others in relation to sustainable social improvement. My ultimate goal was to identify the extent to which architectural design strategies could ameliorate the current state of social housing within a global context; and while my main goal remains the same, my focus has significantly shifted from the comparison of three countries to the critical review of a single country, Canada.

Upon reviewing the literature introduced to me by my thesis supervisor on housing policy, poverty, and federal involvement, it became clear that my parameters were too ambitious and that I needed to place undivided attention on the country before me. The urgent need to provide new social housing in Canada became evident to me from the plain, cold statistics that point to an alarming 71,000 families currently on the (social-housing) waiting list, 720,000 Canadians who had to make use of food banks last year, and 150,000 to 300,000 Canadians who are homeless. Ever since the federal government downloaded its responsibilities in 1993 and the provincial government followed suit in 1998, funding has become a major issue. New construction ceased (and never recovered), and the existing social-housing stock continues to deteriorate.

Past - Present - Future: The Revitalization of Social Housing in Canada 
Figure 1.00 below proposes a graphical framework highlighting some of the critical (policy-driven) events that have contributed to the present state of social housing in Canada.

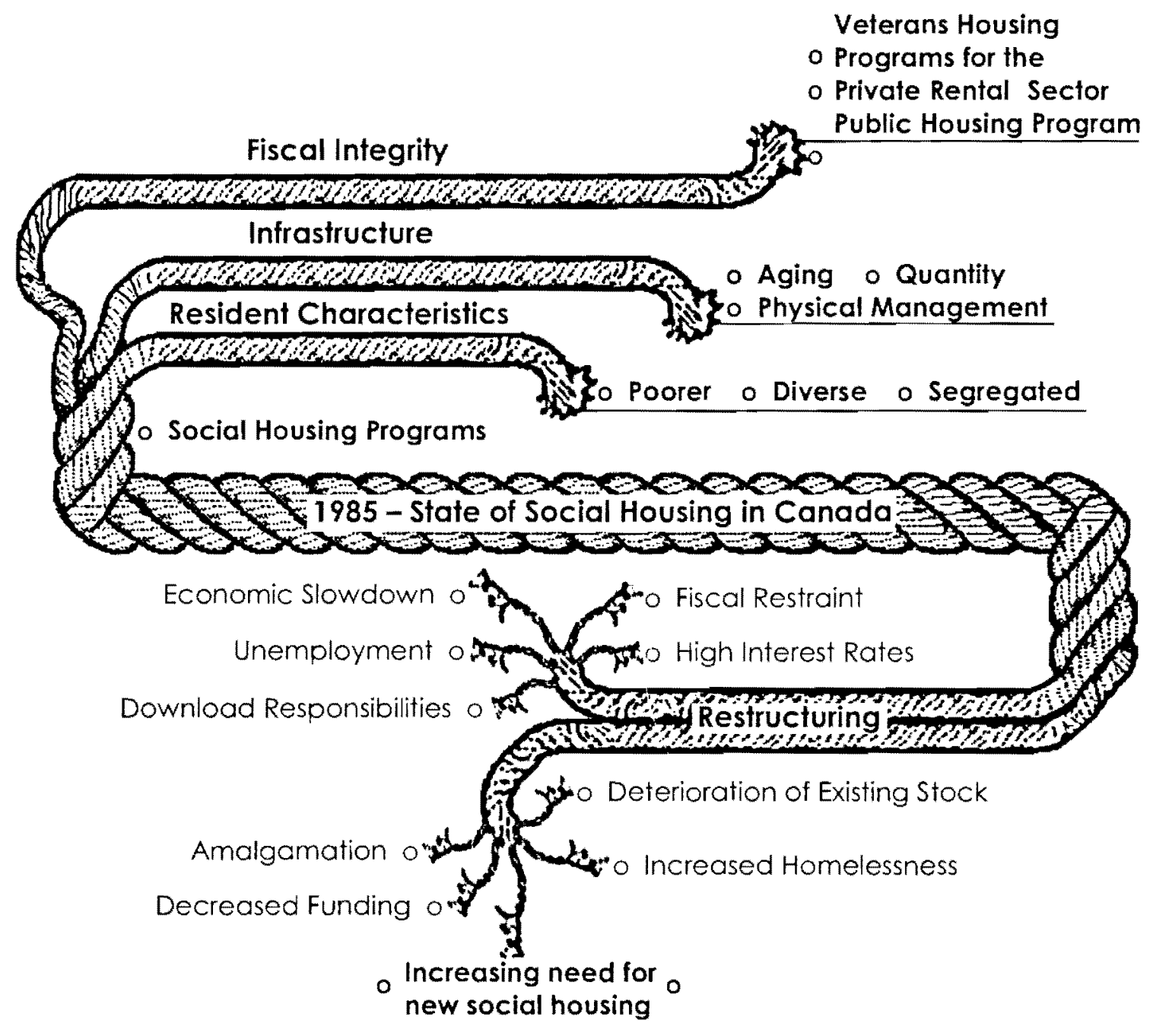

Figure 1.00. Conceptual Framework of Canadian Social Housing Policy (1946 - Present). 
My review of the state of social housing begins in 1946, when the federal government formed a Crown corporation primarily to provide housing for returning veterans in a time of fiscal integrity. This led to the creation of several housing programs geared towards stimulating private-sector involvement and development. With the introduction and eventual failure of the public-housing program (primarily due to the high concentration of low-income individuals and absence of supporting services), an alternate approach to social housing emerged (ca. 1973) in such forms as mixed-use, lower-density, nonprofit housing and co-ops. This type of housing development would continue to flourish through to a period of fiscal restraint, exacerbated by the recession of 1981 to 1992, until its demise in 1993, when the federal government downloaded responsibilities to provincial governments. Little-to-no new activity has occurred since then, because of further downloading, of provincial responsibilities to municipal governments. The resulting withdrawal of funding and involvement has significantly impacted social housing today.

Architecture has the ability to transform spaces, dictate or suggest functions, and create fusion within a given environment. As we depart from the monolithic, low-income-concentration, high-density approach to social housing of the 50 s and 60s (Pruitt-lgoe, Regent Park, Cabrini Green), let us embrace a future of compelling architectural intervention. No longer should housing strategies for those in need be a mere reflection of building-code requirements. Instead, they should be a contribution to the design world, worthy of the kind of celebration fit for any museum, school, or office building.

"What we build not only reflects, but also serves all of society, and not just those who can afford it. It is our duty to use our skills, knowledge and resources to provide for those with the greatest need and the fewest options" (Sam Davis).

This body of work is laid out in the following manner: Within the literature review, I note a critical need for not only the extensive remediation of the existing social-housing stock across Canada, but also the introduction of new stock to service current and future needs. Upon establishing this foundation as a point of departure, the research methodology reviews some of the (now-demolished) public-housing projects of the past and follows with an investigation of a few recent architecturally designed projects around the world.

Past-Present - Future: The Revitalization of Social Housing in Canada

thesis student: thesis supervisor: date: Johann Atterbury | Joseph Springer | 25-September-2009 
An analysis of the research and collected data reveals a promising future for social housing and architecture. The $21^{\text {st }}$ century has seen the emergence of individuals such as Sam Davis, a Californiabased architect who now focuses on housing for the homeless, and other architects from countries such as Spain, Slovenia, and Europe who are embracing a symbiotic relationship between social housing and sustainability. This is a fusion that is critical to the design of all buildings today, certainly, but also specifically to social housing, where operating and maintenance costs are constantly and increasingly difficult to sustain as a result of subsidized rentals being paid by tenants.

If we continue to build on the achievements of people like Sam Davis, and unceasingly seek ways of reducing the carbon footprint of what we build, and with renewed federal funding as a catalyst, higher levels of architectural involvement can create a new character and identity for social housing of the future. If we, as a country, are flourishing, yet there are persons desperately struggling, should you as an individual not rethink your priorities? It is often said that 'you are as strong as your weakest link.' Is this not also the case for a country? 


\section{Literature}

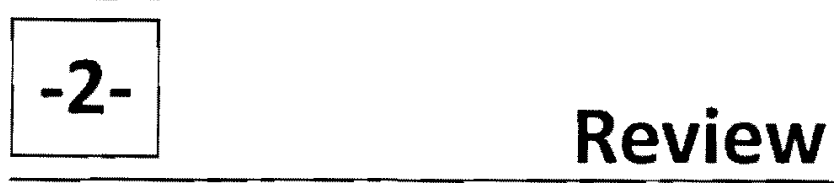

"If you are neutral in situations of injustice, you have chosen the side of the oppressor. If an elephant has its foot on the tail of a mouse and you say that you are neutral, the mouse will not appreciate your neutrality."

Archbishop Desmond Tutu 


\section{Overview}

This literature review serves to provide a background for the discussion surrounding my selected topic. The relevant literature has been broken down into a series of subheadings that have been selected in an attempt to acknowledge the complexities of social housing in Canada. Each section is written as a position piece and presents a critical evaluation of the existing literature on the subject. This establishes a point of argument and/or formulates questions for further discussion/exploration.

The 'Historical Context' investigates the condition and quantity of the existing social-housing stock, and the extent to which new social housing is required. 'The Federal, Provincial, and Municipal Role' points to the fact that since the federal government downloaded its responsibilities in 1993 and the provincial government followed suit in 1998, funding has become a major issue. New construction ceased (and never recovered), and the existing social-housing stock continues to deteriorate. 'The Emergence of a Governing Social Housing Provider' identifies the largest social-housing provider in Canada, which continually struggles with finding a modernization and improvement budget for its existing portfolio (let alone new stock) due to insufficient federal and provincial funding. This chapter concludes with the review of a very promising 'Existing Remediation Proposal' in the City of Toronto's Mayor's Tower Renewal project; and while this initiative will address the immediate need to renovate existing structures in that city, there is still great demand for new housing, which requires urgent attention in tandem with projects such as these.

All areas point to an urgent need to remediate and increase the social-housing stock.

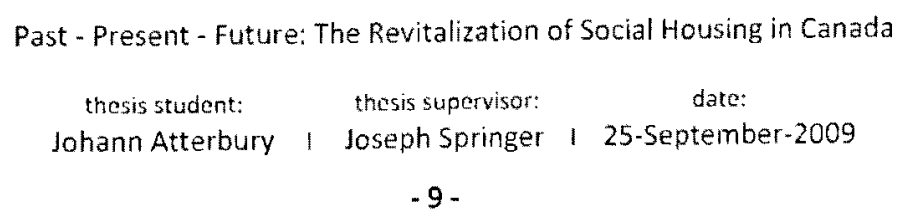




\section{Social Housing in Canada: Acknowledging the Complexities}

\section{Historical Context}

Canadians have been referred to as being among the best-housed people in the world. This is largely due to the continuing, collective efforts of the State (for example, CMHC (Canada Mortgage and Housing Corporation, as of 1979) and provincial ministries) and the private and non-governmental sectors in meeting the extensive housing needs of the post-war era. The Central Mortgage and Housing Corporation opened its doors for business in 1946, with its primary goal being to rapidly provide housing for returning war veterans. The $\mathrm{CMHC}$ is the housing agency of the federal government and is responsible for administering the National Housing Act (Hulchanski, 1988).

This urgent need for housing was an ongoing crisis, gaining momentum from the depression years when people could not afford to build houses, and continuing into the war years when labour and materials were not readily available. The sense of urgency prevailed for several years until:

The problem of producing enough new housing after the war was solved by the late 1960's when the house building and house financing capacity of the nation was no longer a problem. Canadian housing policy helped shape the mortgage lending system, helped develop the house building industry and played a significant role in the municipal land servicing process. House production objectives were achieved, though distributional and equity considerations were ignored. The aim of Canadian housing policy has been to make ownership of a detached house and, more recently, a condominium or townhouse, a feasible option for those able to qualify for a mortgage. (Hulchanski, 1988, p. 18)

Home ownership is certainly a dream of most Canadians, but unfortunately not a reality for many; and while great strides have been made in the development of housing (see figure 2.00), the federal government has consistently placed greater emphasis on home ownership rather than rental (specifically non-market). "In the early 1940s, Canada had a housing stock of [less than] three million units (compared to twelve and a half million now)" (Canadian Housing Observer 2006, pp. 37). 
Of this 12.5 million, however, only five per cent (or 650,000 units) represents the entire, federally assisted public and social-housing stock (see figure 2.01) (Van Dyk, 1995). "About 60\% of Canada's households are homeowners; the other $40 \%$ rely mainly on the private rental sector" (Hulchanski, 2001).

\section{Timeline of Housing Involvement of the CMHC}

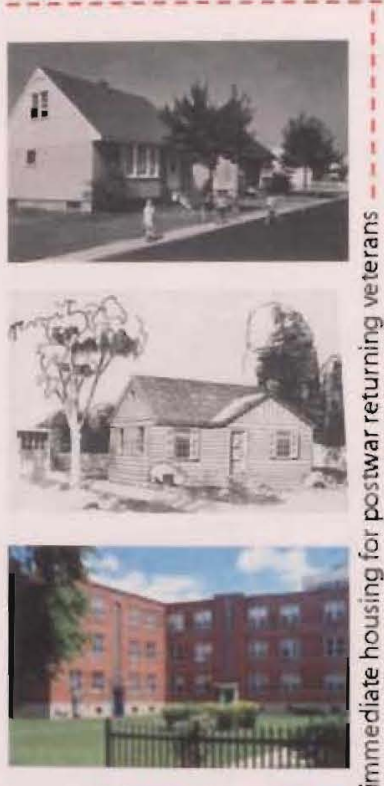

mid 1940 's to mid 1950 's $\lrcorner$
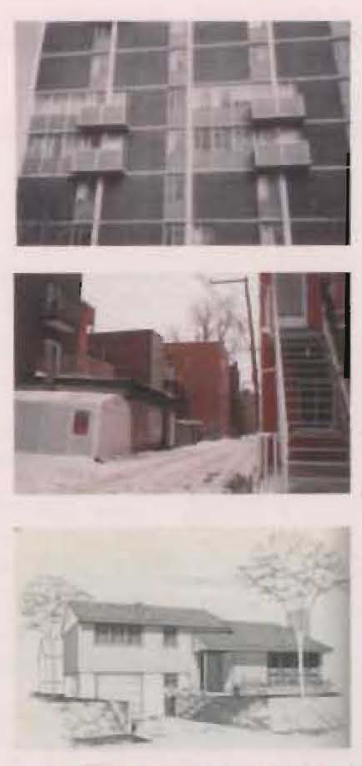

early 1950 's to mid 1960's J
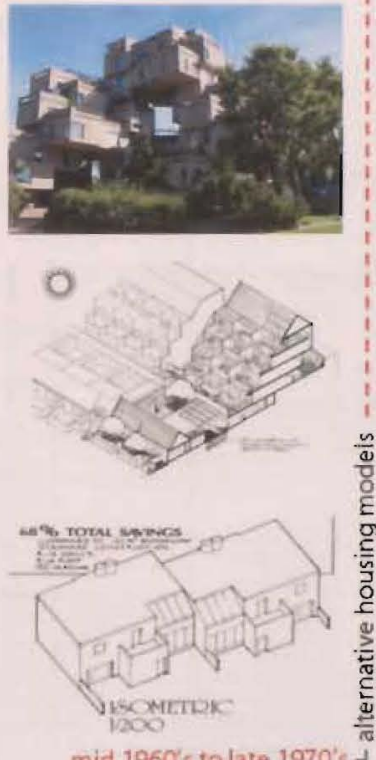

mid 1960 's to late 1970 's $\lrcorner$
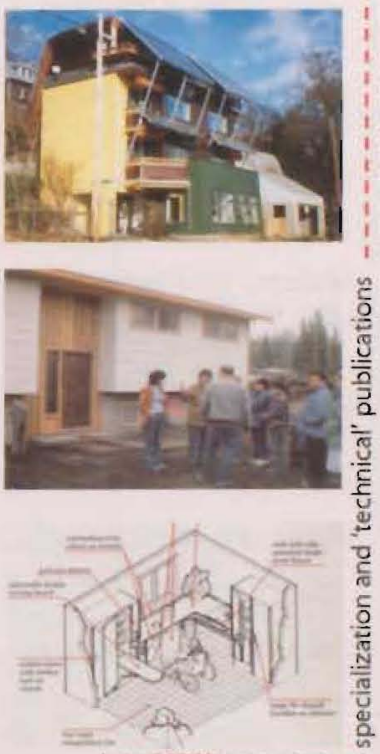

late 1970 's to present $d$

Figure 2.00. Timeline of Housing Involvement of the CMHC. From: Atterbury, 1., 2008, The role of the CMHC in revolutionizing housing types in postwar Canada (unpublished), p. 21. 


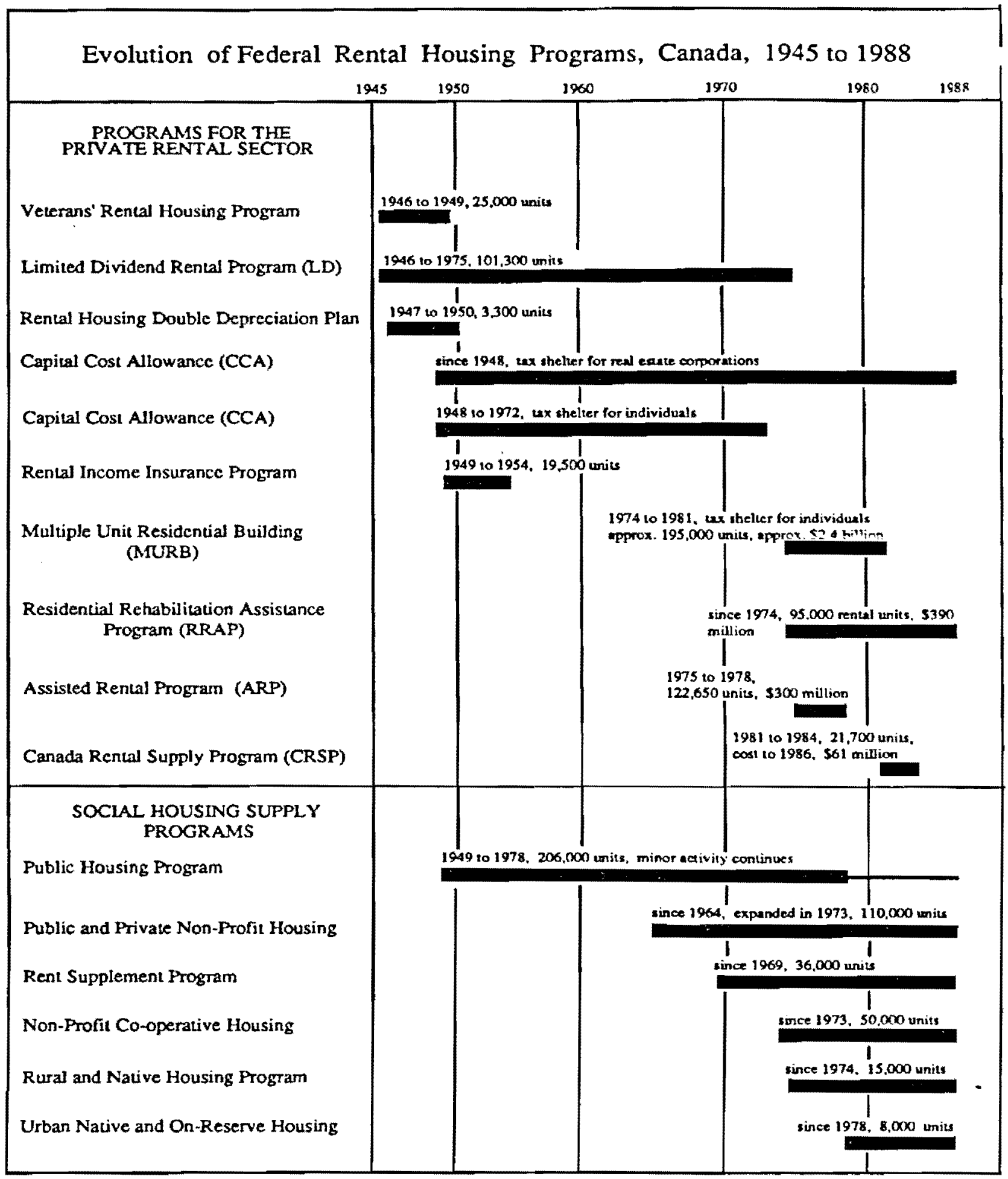

Figure 2.01. Evolution of Federal Rental Housing Programs, Canada, 1945 to 1988. From: Hulchanski, J. D., 1988, Canada's housing and housing policy: an introduction, p. 36. 
But what exactly does it mean for Canada to have a social-housing stock of five percent? How should this statistic be understood? Should it be compared with the social-housing statistics of European countries, where the average stock is 20 percent? Would it then be safe to presume that the population outside this five per cent exists above the poverty line, as measured, for example, by the low-income cut-off point? "The LICO, or Low-Income Cut-off, is a relative measure of poverty used by Statistics Canada. It takes into account both family size and city size to establish income thresholds. In 2000 , the LICO for Toronto was $\$ 34,572$ for a family of four and $\$ 18,371$ for a single person" (Toronto Report Card on Housing and Homelessness, 2003, p. 4) (see figure 2.02). Would the remainder of the population fall somewhere within the 60 per cent of homeowners and 40 per cent of market-rate renters?

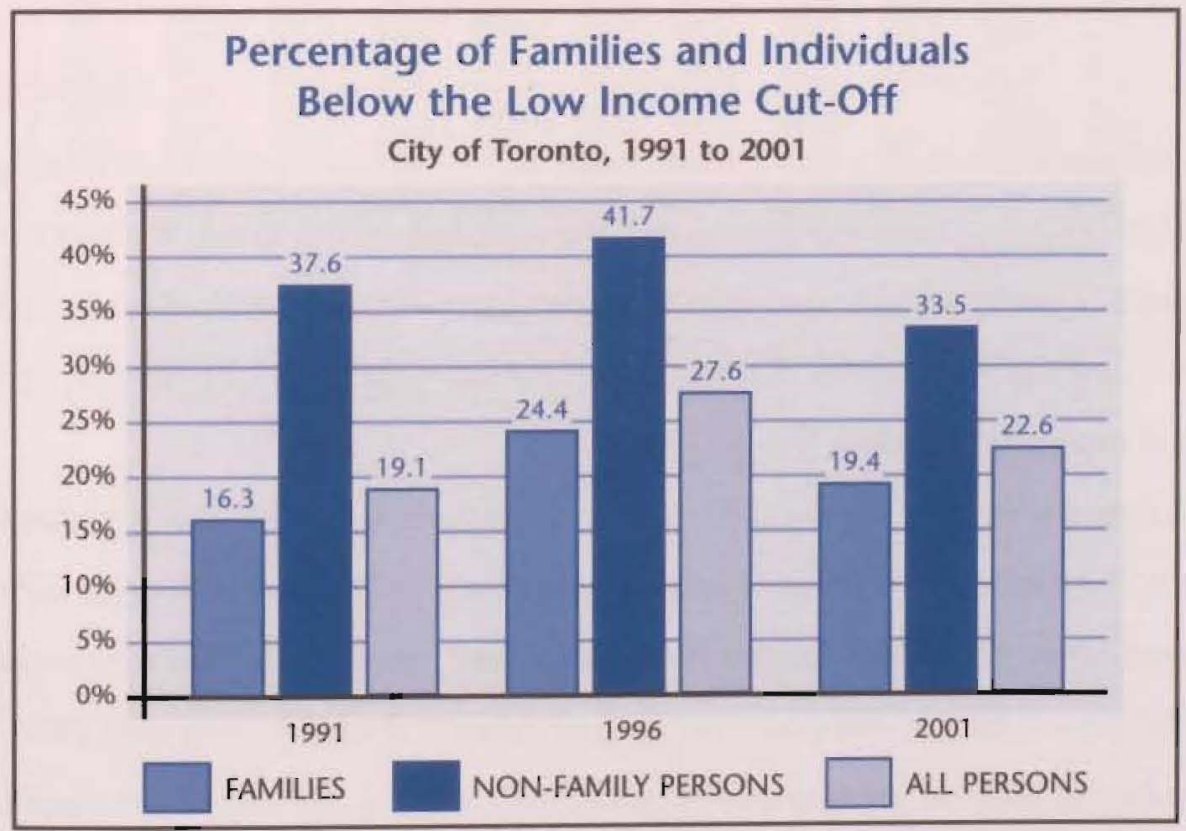

Figure 2.02. Percentage of families and individuals below the low income cut-off, city of Toronto, 1991 to 2001. $19 \%$ of families and $38 \%$ of singles had incomes below the Low-Income Cut-off 2 (LICO) in 2001. This represents 552,300 people, or roughly one-quarter of the city's population. Despite improvements in the economy, poverty is still a serious issue for many Torontonians. Relative to the Greater Toronto Area (GTA), the City of Toronto has more people living in poverty and they are getting poorer. Some new immigrants are struggling to become established. Newcomers may face language and cultural barriers and often find that their professional credentials are not recognized. From: City of Toronto, 2003, Toronto Report Card on Housing and Homelessness, 2003, p. 4. 
The Toronto Report Card on Housing and Homelessness (2003) offers a different, albeit slightly dated, perspective.

Toronto's economy has grown stronger in recent years. Unemployment rates are down and incomes are up. Rental housing vacancy rates are rising. Low interest rates have created a robust homeownership market. But, as shown by the statistics below, not everyone is benefiting from these improvements.

- 552,300 people, or a quarter of Toronto's population, still live in poverty

- From 2000 to 2002 , only $3 \%$ of new housing construction was for rental units ( 873 units) compared to $97 \%$ for the home-ownership market $(28,492)$

- Toronto rents rose by $31 \%$ between 1997 and 2002

- Today, only $20 \%$ of private rental apartments rent for less than $\$ 800$ a month

- More than $25 \%$ of tenants in Toronto have annual incomes below $\$ 20,000$

- More than 250,000 tenant households pay more than $30 \%$ of their income on rent; $20 \%$ pay more than $50 \%$

- The social housing waiting list now stands at 71,000 households

- 31,985 different people stayed in Toronto's emergency shelters in 2002: 4,779 were children (p. 3).

These numbers indicate a 'hidden' population that currently exists within Canada, which, without immediate action, will continue to grow in tandem with the increasing separation between high- and low-income earners. Concrete evidence of the existence of this group is offered by the fact that 720,000 Canadians had to make use of food banks in March 2007, and that 150,000 to 300,000 Canadians remain homeless in a country that had a national net worth of $\$ 5.4$ trillion by September 2007 (\$163,700 per capita) (Perception, Vol. 29, 2008).

There is a growing demand for social housing in Canadian cities. This is largely due to the rise in housing costs for both home ownership and rental. "As recently as 1996 , [rental] units under $\$ 800$ per month made up more than $65 \%$ of the market [in Toronto] (see figure 2.03 ). They now make up only about $20 \%$...In 1996 almost $90 \%$ of one-bedroom units in Toronto rented for less than $\$ 800$, now only 25\% do" (Toronto Report Card on Housing and Homelessness, 2003, p. 9). The current lack of affordable rental housing can be attributed to several factors, including condominium conversions, the lack of new rental units being built, funding cuts to government programs, neighbourhood gentrification, and urban population growth (Wilkie, 2007). What is becoming evident through this research is the urgent need for additional social housing, as well as the need for extensive remediation of the existing stock.

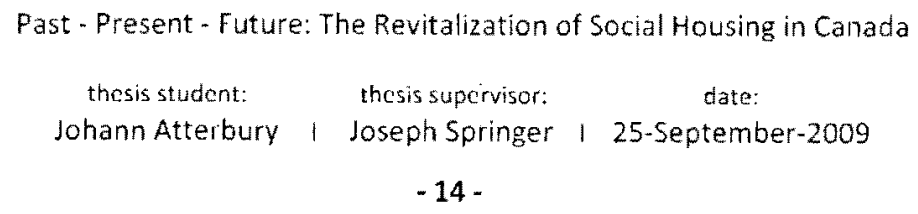



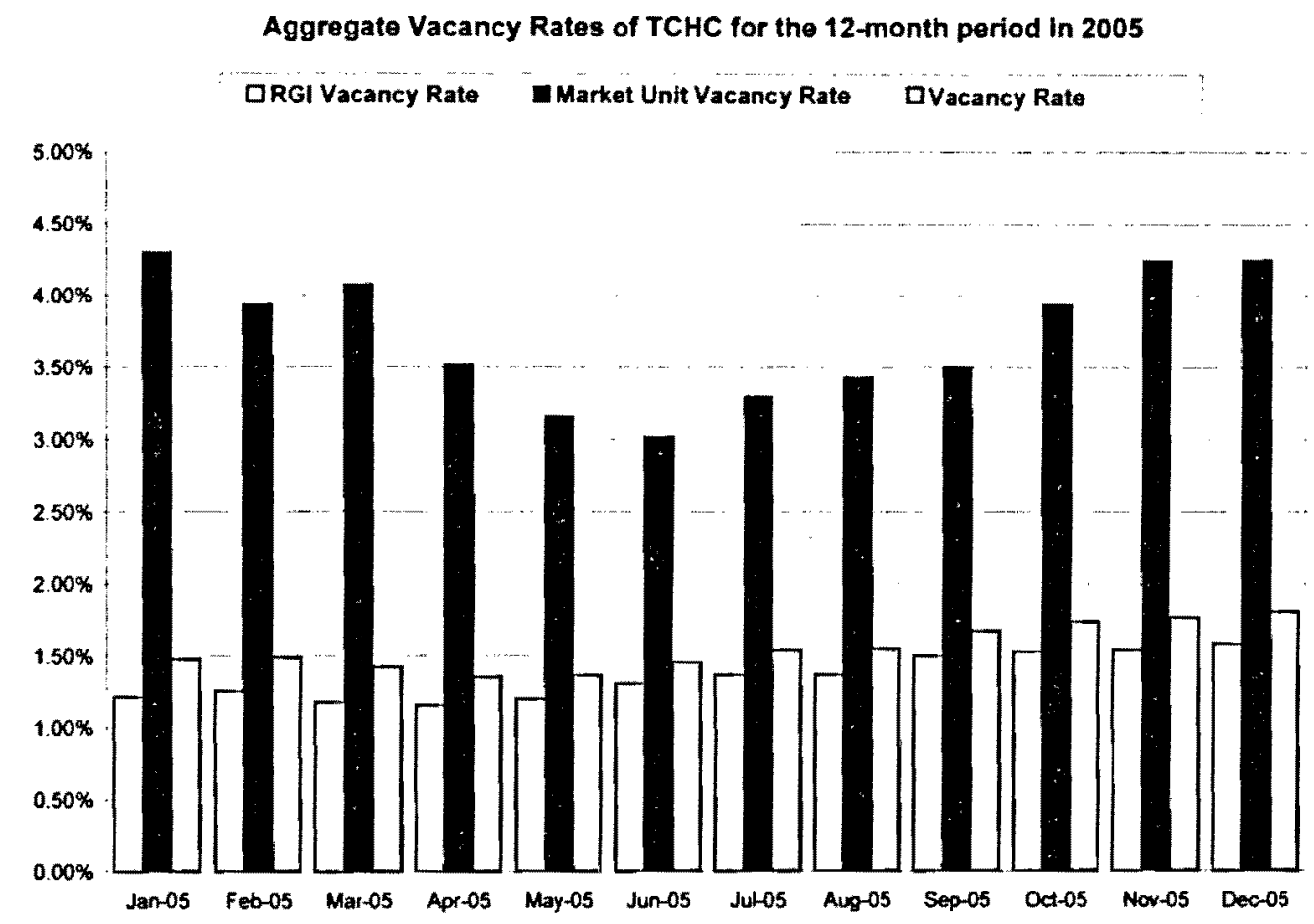

Figure 2.03. Vacancy Rates of Toronto Community Housing Corporation (TCHC) for 2005. Indicates a severely low rent-geared-to-income vacancy rate, compounding the need for an addition to the existing social housing stock. From: TCHC Offering memorandum, 2007, p. 26. 


\section{The Federal, Provincial, \& Municipal Role}

The federal government supported the public-housing program from 1949 to 1978 under Sections 79,81 and 82 of the National Housing Act, by either absorbing 75 per cent or jointly dividing cost and operating shares with the provincial (and, to a lesser extent, municipal) governments. This initiative saw the realization of approximately 4,800 public-housing projects, containing just over 205,000 units (Evaluation of the Public Housing Program, 1990). These units are part of the five percent of households that represent the entire (non-market) social-housing stock across Canada, compared with 40 per cent in the Netherlands, 22 per cent in the United Kingdom, 15 per cent in France and Germany, and two per cent in the United States. "By 1993, all federal support for housing was withdrawn. The supply of social housing fell from an annual level of 25,000 new units in 1983 to zero in the 1993 budget" (Hulchanski, 2002, p. iii). In 1993, the federal government ceased allocation of new money to social housing.

In the past, senior levels of government funded a social safety net able to respond to changing social and economic needs by providing adequate levels of supports such as social assistance and social housing. However, over the last 20 years, funding cuts have weakened these critical programs. Among actions taken at the federal level, in 1993, the government withdrew its funding for new social housing, followed soon after by the Province in 1995. Next, the Province cut social assistance benefits by $21.6 \%$ in 1995 and in 1998 eliminated rent controls on vacant private rental units. The results of these actions have left many people struggling to find housing with less money in a private rental market prone to rising rents. (Toronto Report Card on Housing and Homelessness, 2003, p. 3)

According to a CMHC report of the late 1980s, the public-housing stock across Canada was in good overall condition. With at least 94 per cent of the entire portfolio meeting or exceeding the NHA minimum housing standards, the general outcome of project implementation would seem to have been quite successful (Evaluation of the Public Housing Program, 1990). But how does one truly measure success in a case such as this? Carver (as cited in Hulchanski, 1988, p. 47) claims that "the crucial and ultimate test of the effectiveness of housing policy is the condition of the worst-housed families in our communities." I agree with this statement and would be far more interested in analyzing and understanding the conditions faced by those living in the substandard six percent of units, and what could be done to remediate this present state. I believe that, as humans, we react differently to situations based on our position in life, and if one were to gain feedback from an individual living in one of the units that comprise the sub-par six percent, chances are they would not be pleased with their current situation; so why should we be?

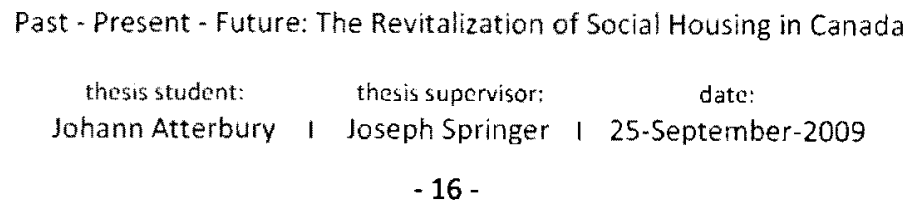


It is on this premise, I feel, that the issue of social housing should be approached with a 'rockbottom upward' remediation mentality. If the ultimate goal is to 'adequately house all Canadians,' then it seems logical that greatest emphasis be placed upon those who are 'not' adequately housed. The CMHC report went on to mention that the 6.3 percent of units that fell below the NHA minimum standards represents an estimated 169 projects containing close to 13,000 units (Evaluation of the Public Housing Program, 1990). A conservative assumption of two persons per household would reveal some 26,000 persons living below the minimum housing standard. Areas such as these should be targeted and brought forward for urgent attention.

Further budgetary studies done by the $\mathrm{CMHC}$ revealed an estimated repair and replacement cost of $\$ 350$ million (as of 1988) and a need for an additional $\$ 133$ million for upgrades in areas of fire safety, lighting, ventilation, energy efficiency and durability (Evaluation of the Public Housing Program, 1990). With a 1988 maintenance and modernization and improvement (M\&I) budget of $\$ 274$ million, this created an overall backlog of $\$ 209$ million. This level of funding and lack of meeting the minimum amount required for repairs and upgrades (let alone the construction of new stock) has been an ongoing trend of the federal government, which officially withdrew its new social-housing involvement in 1993 (see figure 2.04).

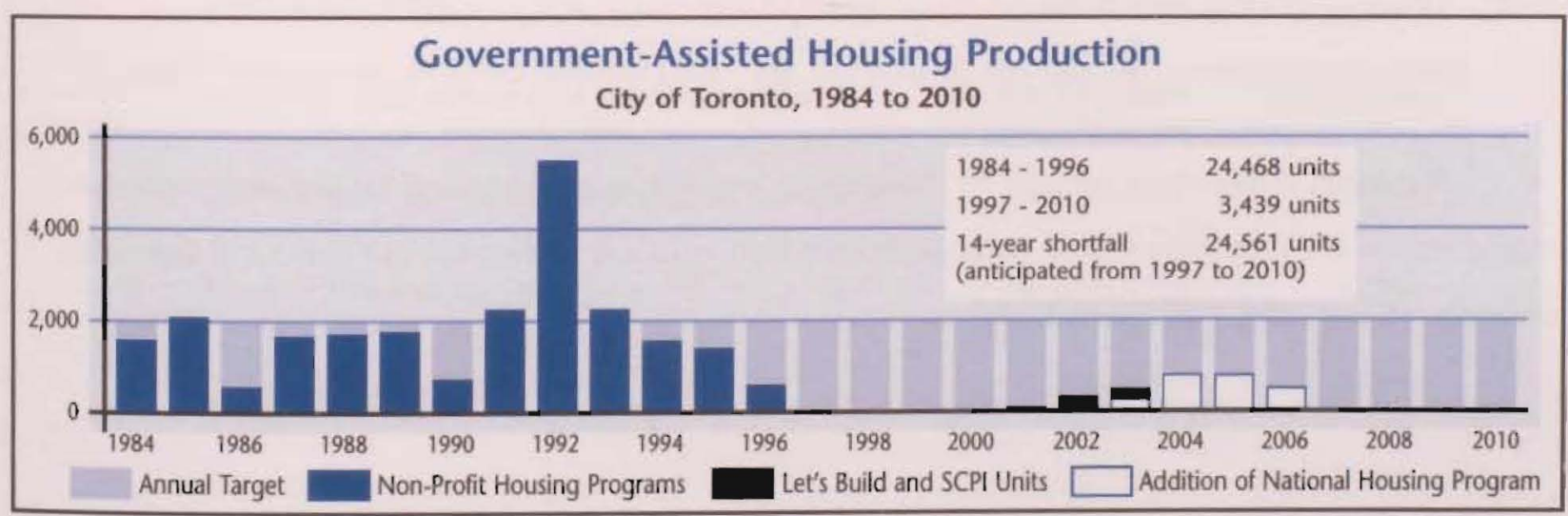

Figure 2.04. Government-assisted housing production, City of Toronto, 1984 to 2010. The Mayor's Homelessness Action Task Force set an annual development target for Toronto of 2,000 affordable rental units. It has also been estimated that 2,000 new conventional private rental market units are needed annually in Toronto. The 873 rental units built in the last three years represents an annual average of less than 300 units - far short of these targets. The chart shows the current and future shortfall of affordable housing in Toronto based on the Task Force targets. Even taking into account new units built through Let's Build, SCPI (federal Supporting Communities Partnership Initiative) and the new federal housing program, there is a very large shortfall of thousands of units resulting from the lack of new rental supply in recent years. This provides a good measure of the size of Toronto's housing problem. From: City of Toronto, 2003, Toronto Report Card on Housing and Homelessness, 2003, p. 7. 


\section{The Emergence of a Governing Social Housing Provider}

Scattered across Canada are several social housing providers. These organizations oversee and regulate the maintenance and general operation of the existing social housing stock. Toronto alone has 230 providers and is home to the largest social housing provider in Canada. The Toronto Community Housing Corporation (TCHC), an integration of the Toronto Housing Company ( $\mathrm{THC}), \mathrm{CityHome}$, and the Metropolitan Toronto Housing Corporation (MTHC) was formed in 2002. TCHC manages 164,000 low and moderate-income tenants (6\% of Toronto's population) in 58,500 households, including seniors, families, singles, refugees, recent immigrants to Canada and people with special needs. The physical structures used to house these individuals represent an aging (public housing) stock downloaded by the provincial government without the necessary funding to raise it to an acceptable standard. The majority of stock is 30 years or older and is categorized as follows:

- Units in low-rise elevatored apartment buildings average 38 years of age - $3 \%$

- Units in mid-rise elevatored apartment buildings average 29 years of age - $13 \%$

- Units in high-rise apartment buildings average 30 years of age $-61 \%$

- Townhouses and walk-ups average 38 years of age $-20 \%$

- Units located in houses average 68 years of age - $3 \%$ (Toronto Community Housing, 2008)

The TCHC attempts to achieve its mandate to "provide quality housing for low-and moderateincome households" with annual funding generated from rental revenues (52 per cent) and operating subsidies (48 per cent) (see figure 2.05 ).

Past - Present - Future: The Revitalization of Social Housing in Canada

thesis student: thesis supervisor: date:

Johann Atterbury | Joseph Springer | 25-September-2009

-18 - 


\section{Revenues}

2007 Revenues:

$\$ 564$ Million

Rent and associated revenue

$292,914,977$

$52.0 \%$

Federal and GTA pooling

$133,812,707$

$24.0 \%$

City of Toronto operating subsidies

$137,526,046$

$24.0 \%$

$564,253,730$

\section{Expenditures}

2007 Operating Expenditures:

$\$ 564$ Million

Municipal Taxes

$101,813,162$

$19.6 \%$

Utilities

$106,764,519$

$18.9 \%$

Debt payments

$92,572,930$

$17.5 \%$

Building operations and maintenance

$82,743,649$

$14.7 \%$

Capital plan funded by operating cashflow

$77,577,186$

$13.7 \%$

Tenancy management

$24,218,182$

$4.3 \%$

Corporate services

$18,728,278$

$3.3 \%$

Net reserve contribution

$18,032,948$

$3.2 \%$

Community support and community safety

$17,495,180$

$3.1 \%$

Other operating costs

$8,874,994$

$1.7 \%$

Figure 2.05. Toronto Community Housing's 2007 Financial summary. From: Toronto Community Housing, 2008. 
The 2007 numbers reveal a tight budget that affords little or no capacity for modernization and improvement ( $M \& l)$ of the existing stock and makes even less likely the introduction of new stock to the TCHC portfolio.

Nearly six per cent of Toronto's population,164,000 people with low and moderate income, live in over 2,000 deteriorating buildings that are up to 50 years old and in need of urgent repair and refurbishment. Families are forced to live with chronic faulty wiring and plumbing, leaky ceilings, broken doors and windows, rundown playgrounds and unsafe entrance lobbies and public spaces. They deserve better. It is not right for our fellow Canadians to be left behind. Toronto Community Housing does not have the money to keep up with major repairs and the most serious problems. The gap between the present budget and the cost of capital repairs is an astonishing $\$ 300$ million, and growing. The problem is real, it is urgent and it is only getting worse. And while there is a great need to create new affordable housing, there is an immediate need to fix the existing 250,000 units across Ontario or risk the financial burden of large scale replacement (a $\$ 40$ billion replacement cost).

(Toronto Community Housing, 2008) 


\section{Existing Remediation Proposals}

The City of Toronto (municipal government) has produced several publications dealing with such issues as affordable housing, homelessness, food and hunger, and shelter. These publications seek to track the city's progress in combating some of the critical issues, and produce a quantitative record to place before senior levels of government for further intervention. The Toronto Report Card on Housing and Homelessness is one such publication. It points to the fact that there is an urgent need for extensive renovation of the existing social-housing stock, as well as the introduction of new stock. The federal government downloaded its responsibilities in 1993 and then, following the provincial Local Services Realignment, in 1998, funding became a major issue. New construction ceased (and never recovered), and the existing stock continues to deteriorate.

In response to the need for modernization and improvement of existing stock, the City of Toronto is implementing the Mayor's Tower Renewal project, a multi-faceted building upgrade of 1,000 unsustainable towers in the city, thereby supporting community reinvestment and greening initiatives, fostering vibrant communities, and reducing greenhouse gasses throughout Toronto (Opportunities Book, 2008) (see figure. 2.06).

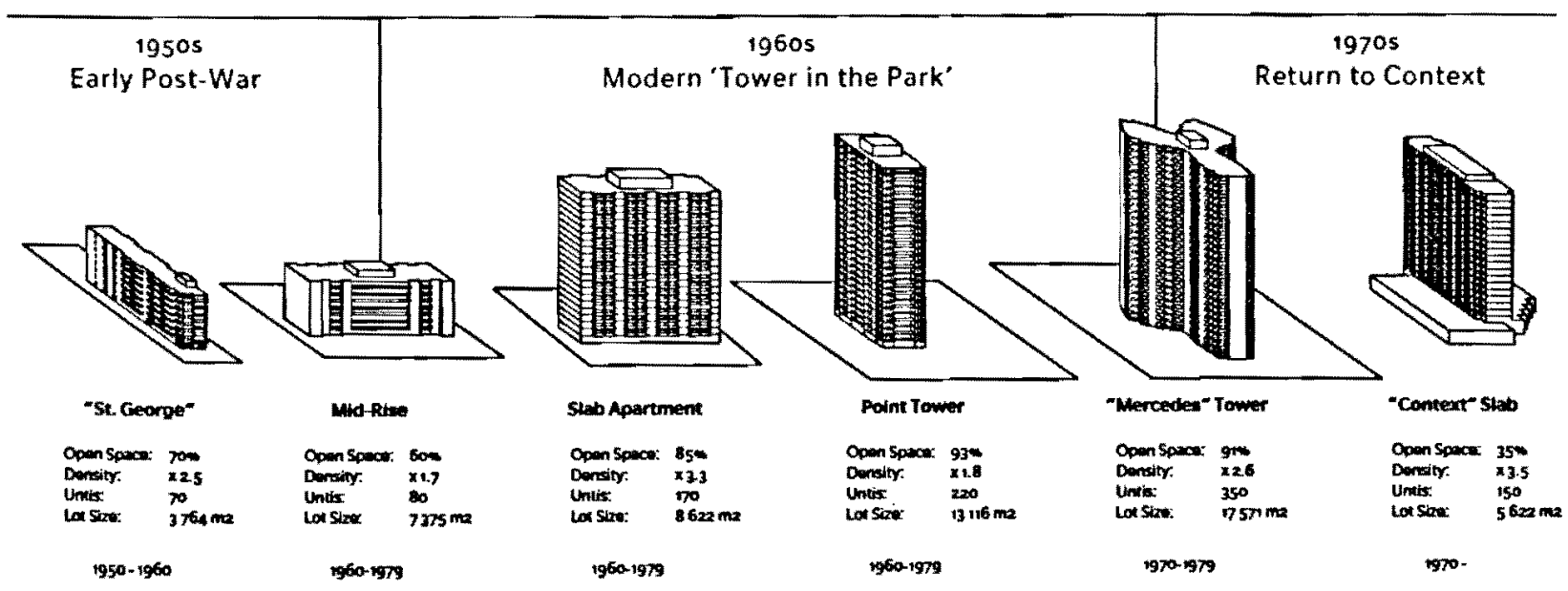

Figure 2.06. Chronology of modern apartments in Toronto. From: Opportunities Book, 2008, p. 17. 
As we embrace an era of sustainability and environmental awareness, it is imperative that we identify ways and means of reducing our carbon footprint within any given area. In addition to the 'renewal' of deteriorating buildings that are up to 50 years old and in need of urgent repair and refurbishment, this project aims to provide a response that will reduce the current carbon output of these inefficient buildings from $900,000+$ tonnes of $\mathrm{CO}_{2}$ to 230,000 tonnes of $\mathrm{CO}_{2}$ (Opportunities Book, 2008) (see figures 2.07 and 2.08).

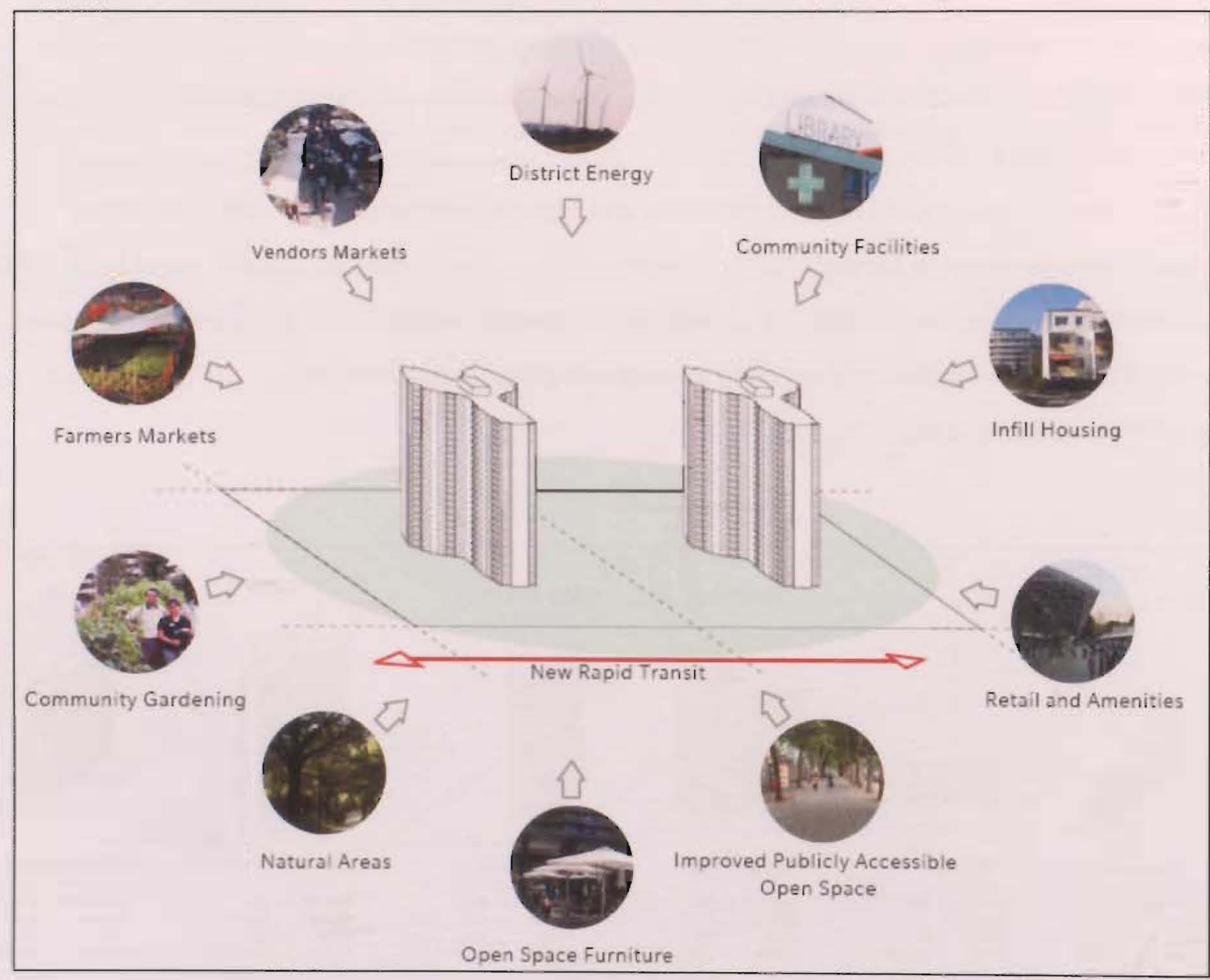

Figure 2.07. Opportunities for complete communities. Truly sustainable neighbourhoods are more than simply efficient buildings, they are communities organized in a fashion promoting social, economic, cultural and ecological health. The Province's Places to Grow document promotes the creation of 'Complete Communities'; neighbourhoods which provide the full range of services and amenities, housing types and tenures, accessibility, equity, as well as ecological responsibility. Neighbourhoods which are vibrant, self-sufficient, and in which residents are proud to call home. From: Opportunities Book, 2008, pp. 76-77. 


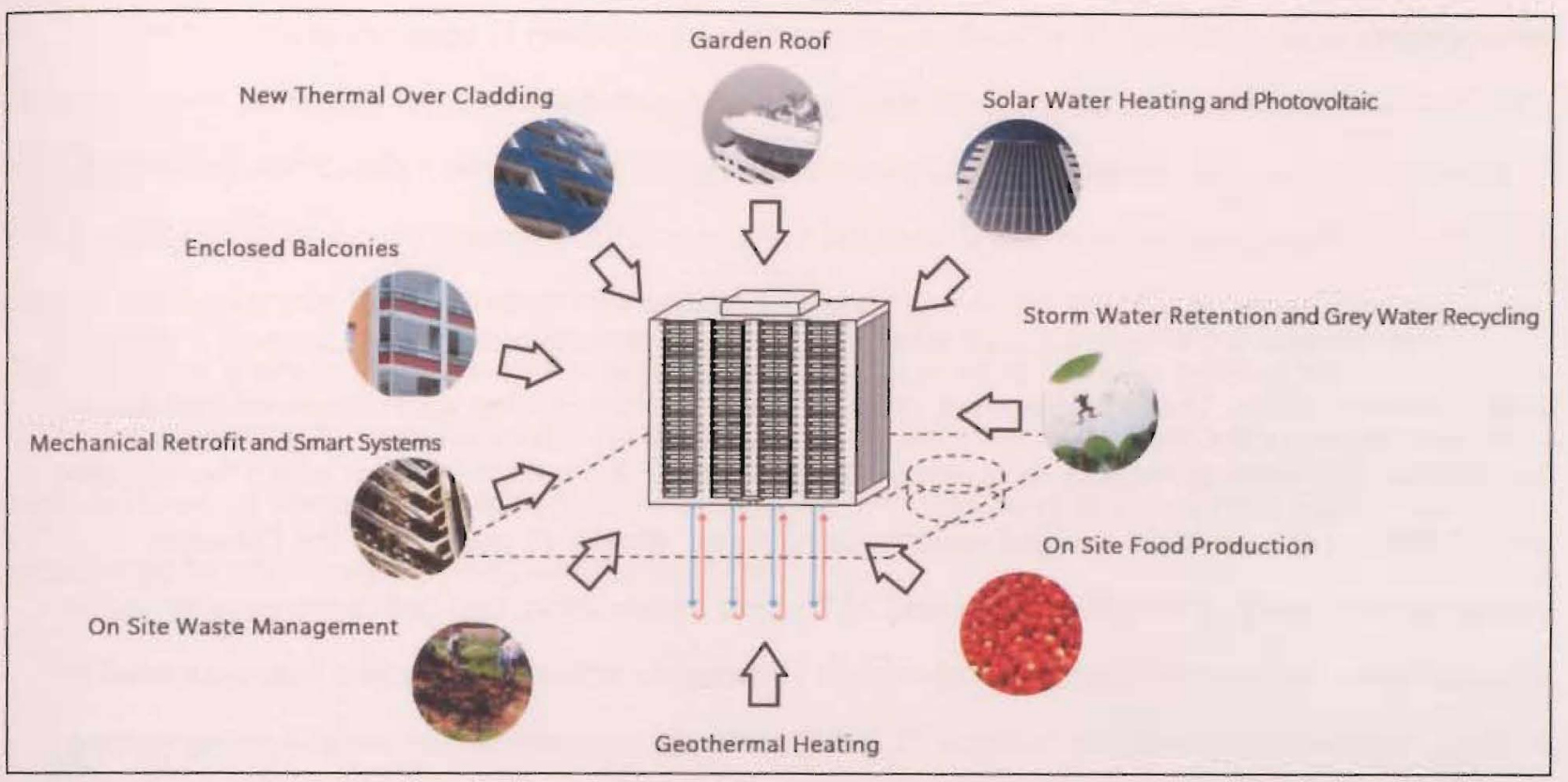

Figure 2.08. Sample strategies for green renewal. The scale of these buildings, many containing several hundred units, provides the critical mass required to make green retrofits viable. Investments are also possible at the neighbourhood level, such as district energy, auto-sharing, community gardens and on-site waste management. Furthermore, the addition of a mix of uses providing local services and amenities will reduce the need for auto trips, and more importantly, foster vibrant and self sufficient communities. From: Opportunities Book, 2008, p. 68.

Four pilot sites (one of which is TCHC owned) have been chosen "to demonstrate the potential of city-wide ... renewal and to coordinate with additional Council priorities like the Transit City plan, the Agenda for Prosperity, the work of the Neighbourhood Action Teams and the Climate Change, Clean Air and Sustainable Energy Action Plan" (Mayor's Tower Renewal, Pilot Sites, 2008). This proposal seeks to introduce a promising response for the modernization, improvement, and extensive remediation of the existing housing towers of Toronto. With an approach to preserve these extant, durable, concrete structures, the Mayor's Tower Renewal project provides relief for 1,000 near-derelict high-rise apartments of the 60 s and 70 s. While this initiative will address the immediate need to renovate existing structures, there is still great demand for new housing, which requires urgent attention in tandem with projects such as these. 


\section{Summary}

Percentages are effectively used when establishing a general broad-based sense of a particular issue or circumstance. They are, however, quite misleading when dealing with human-related issues. For instance, the existing housing stock across Canada is over 12.5 million units, of which five per cent (or 650,000 units) is federally assisted social-housing stock. Almost 11 per cent of the Canadian population and, more specifically, 25 per cent of Toronto's population, falls below the poverty line; in absolute terms, this means that 552,300 people in Toronto alone live on an income that puts them in poverty. When coupled with the fact that 71,000 families are currently on the social-housing waiting list, 720,000 Canadians had to make use of food banks last year, and 150,000 to 300,000 Canadians are homeless, it becomes evident that there is an urgent need to increase the social-housing stock in cities across Canada.

The federal government supported the public-housing program from 1949 to 1978 and saw the creation of approximately 4,800 public-housing projects, containing just over 205,000 units. Of this absolute figure, at least 94 per cent of the portfolio was said to have met or exceeded the NHA minimum housing standards in 1988. While this statistic may sound satisfactory, it means that six per cent, or an estimated 13,000 units in 169 projects, did not meet minimum standards at that time. The issue of maintenance and meeting minimum standards has continued to spiral and landed in the hands of the Toronto Community Housing Corporation (TCHC).

TCHC, the largest social-housing provider in Canada, inherited 58,500 units when the provincial government downloaded social housing after 1998, without providing the necessary funding to raise it to an acceptable standard. There are a myriad of social-housing providers across Canada that are dedicated to providing (and maintaining) suitable housing for those in greatest need. Funding is, by far, however, their greatest challenge. Lack of sufficient funding continuously makes it difficult to provide any major sustainable improvements to the existing stock, and means that the idea of introducing new stock is nothing more than wishful thinking. It is imperative that the senior levels of government radically increase their role primarily in the area of annual funding to existing and new social housing.

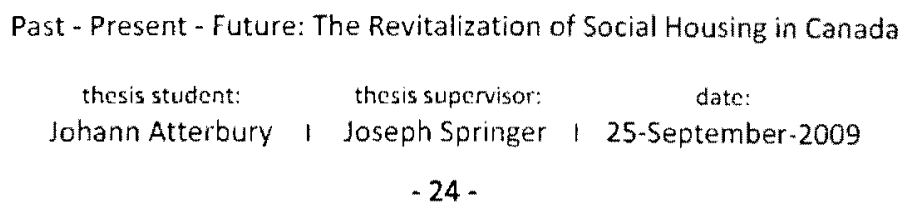


In response to the issue of revitalizing its existing stock, the City of Toronto is implementing the Mayor's Tower Renewal project, a multi-faceted building upgrade of 1,000 unsustainable towers in the city, supporting community reinvestment and greening initiatives, fostering vibrant communities, and reducing greenhouse gasses throughout Toronto. This proposal seeks to introduce a promising response for the modernization, improvement, and extensive remediation of the existing housing towers of Toronto. And while this initiative will address the immediate need to renovate existing structures, there is still great demand for new housing, which requires urgent attention in tandem with renewal projects such as these. It seems increasingly evident that actions and long-term goals urgently need to be established to ameliorate this longstanding problem. 


\section{Research}

\section{Methodology}

"It is not enough to limit your love to your own nation, to your own group. You must respond with love even to those outside it...This concept enables people to live together not as nations, but as the human race." 


\section{Overview}

With the literature review having identified a critical need for new and renewed social housing in Canada, this methodology will provide a reflection on the past and a vision for the present and future of social housing.

The chapter begins with a summary of field data from three interviews/meetings that were completed during this past semester and that provided key information; they were as shown below. The complete collection of field data can be found in Appendix $A$.

- A tenant-engagement meeting, which, as its name suggests, focused primarily on the input of social-housing occupants, rather than on the physical or organizational structures;

- A meeting with a TCHC health promotions officer, who reinforced previously obtained knowledge regarding operations and policy;

- And finally, an interview with an architect who has focused on affordable housing for over 35 years, who responded to questions related to profitability, design principles, typology and the future of social housing.

The focus within the chapter then makes a significant shift to highlight some of the literature written about a few (now-demolished) public-housing projects. These were essentially built to merely reflect the requirements of the building code (by design), and were occupied by a 100 percent concentration of the lowest income earners of society, a combination that was doomed from the beginning.

Finally, this chapter closes on a positive note, with the introduction of some of the more progressive, sustainably designed, social-housing schemes around the world. This is a fusion that deserves celebration and requires continuous integration for a future of sustainable social-housing development. 


\section{Field Data Summary}

* Note: See Appendix A for the complete field data collection.

\section{Toronto Community Housing Corporation: Tenant-Engagement Meeting}

As the name suggests, the TCHC's tenant-engagement meeting was crafted with a specific theme in mind. The focus of this meeting was not a review of the physical structure, nor was it about the company's budgetary constraints (which did manage to surface from time to time); it was rather, a rigorous discussion about how to engage the occupants of the social housing provided by Toronto Community Housing Corporation. I was privileged to attend this, one of an ongoing array of meetings that focused entirely on improving tenant engagement and involvement within their respective communities.

We believe that the best way to address the social and economic challenges facing many of our communities is through the active engagement of tenants, and through collaboration between tenants and community organizations to develop innovative responses to these issues. Toronto Community Housing established the Social Investment Fund (SIF) in 2004 to support community initiatives that build strong and healthy communities. The Social Investment Fund allocates $\$ 1$ million in funding each year to projects that help improve the quality of life in Toronto Community Housing communities (TCHC, 2008).

In addition to the SIF, other methods of engagement were discussed, including options for community management. It was reported that higher levels of involvement had resulted from the introduction of tenant representatives with a leadership role (a prelude to tenant-management-type options). Elected by tenants themselves, these individuals represent some 160,000 tenants (as at 2006). This conversation was closely connected with the issue of ownership; and while 'physical' ownership may be somewhat out of reach, it was suggested that increased engagement and involvement could stimulate a feeling of permanence, self-worth, and the ever-elusive 'sense of place'. Ideas including community gardens (urban agriculture), community kitchens, and drop-ins were also noted as a means of interaction and establishing pride for one's habitable space.

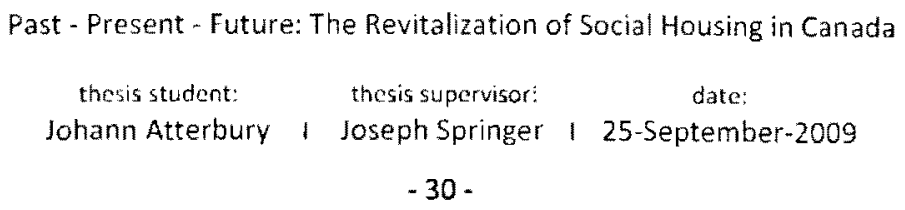


As we embrace an era of multi-disciplinary collaboration, it should be noted that this tenantengagement meeting typifies the notion of collective thinking as a response to the increasingly multifaceted issues plaguing our world today. Meeting attendees included representatives from Toronto Community Housing, Downsview Services to Seniors, Streets to Homes, Eastview Community Centre and Neighbourhood Legal Services, as well as an urban planner and Master of Architecture student, both from Ryerson University. A range of disciplines came together to collectively discuss a single issue while positioning thoughts and opinions based on the individual's area of expertise. This model is gaining momentum within industries and universities alike, and will likely become the normative approach to problem resolution of the future.

\section{Interview - Ed Maichrowski - Toronto Community Housing}

The brief but informative 30-minute meeting with a health promotion officer at TCHC proved to be one that would reaffirm some of my previously researched data. Mr. Ed Majchrowski highlighted the fact that there are thousands of families currently on the social-housing waiting list, that past housing developments that were 100 percent rent geared to income (R-G-I) promoted the 'ghettoization of communities', and that developments now typically comprise 60 percent market rent and 40 percent RG-I. Majchrowski wrapped up by mentioning that shortly before the year 2000 , annual funding was downloaded from the provincial to the municipal government, and that the TCHC is currently lobbying to gain annual funding from the federal government.

\section{Interview - Sam Davis - Affordable Housing Architect}

Being in contact with Sam Davis was one of the highlights of my research, as I was able to access the opinions of an architect who actually specializes in social/affordable housing. It brought with it a sense of reassurance on my part, as I gained confirmation that one can indeed flourish within this particular area of architecture; his 35 years in private practice is a testament to that.

His response to question $\# 4$ is of particular interest to me, as it could potentially set the tone for a typical social-housing design intent or mandate: the notion that building materials used in social-

housing projects ought to be of a quality that would greatly reduce the need for repair and replacement. 
With a goal of constantly seeking ways to minimize operating costs in future developments, Davis aligns himself directly with design ideas of sustainability. This term has now become the normative approach to architectural design, but unfortunately has not been closely linked to social housing. I would strongly argue against this disconnect, and suggest that a fusion such as this is critical to the longevity of socialhousing development. As architects, we constantly seek to meet (and go beyond) the needs of our clients. But how do you design for a client who struggles on a monthly basis to make ends meet, someone whose income is so low that paying even subsidized rent is a problem? Social-housing providers are finding it increasingly difficult to keep rents down as operating costs increase and governmental funding is not consistent. The variable in this case (operating costs) needs to be extracted, revisited, and thoroughly investigated. Imagine a design intent that demanded a building where lights need not be turned on during the day. Or an approach where potable water could be collected, used, recycled, and re-used. There is a critical need to create a symbiotic relationship between social housing and sustainability. 


\section{Regent Park, Pruitt-Igoe, Cabrini-Green:}

\section{Why Early Design Attempts at Public Housing Failed}

"The failures always teach us more than the successes about the design of things. And thus the failures often lead to redesigns - to new, improved things" (Petroski, 2006).

The 1990's brought a dramatic shift in federal policy affecting low-income households, most visibly in the large-scale transformation of public housing nationwide [in the U.S.]. Nowhere has this happened on a grander scale than in Chicago. For decades, Chicago's high-rise "projects," clustered in inner-city ghettos, symbolized public housing's worst failures... These decaying developments were mired in what has been called the most destructive kind of poverty: thousands of extremely low-income, female-headed households struggling in communities dominated by gangs and drug traffickers.

Under agreement with the federal government, the Chicago Housing Authority (CHA) is now demolishing these high-rise projects, relocating their residents, and planning to replace the projects with new, mixed income housing...This process may offer residents new opportunities if policymakers make a serious effort to overcome the mistakes of the past and adopt regionwide strategies that prevent reconcentration and resegregation (Briggs, 2005).

Pat - Present - Fot 
Cabrini Green - Built - 1942. Demolished - 90's

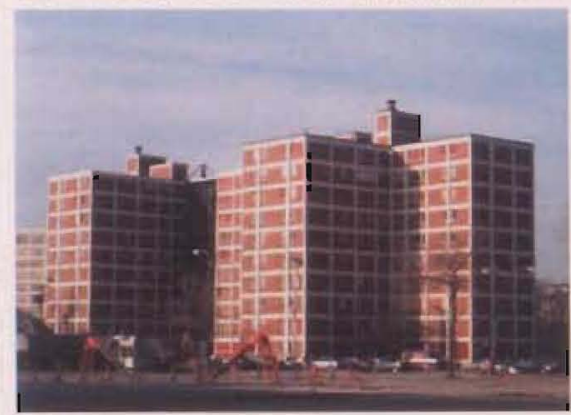

Figure 3.00. Cabrini Green Housing Projects, Chicago, IL. From: freewebs.com
Regent Park - Built - 1948. Demolished - '06

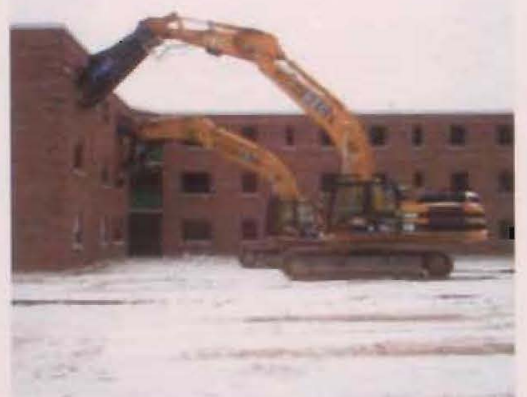

Figure 3.01. Regent Park Housing Development, Toronto, ON. From: environmentalhazards.com
Pruitt-Igoe- Built - 1954. Demolished- 1974

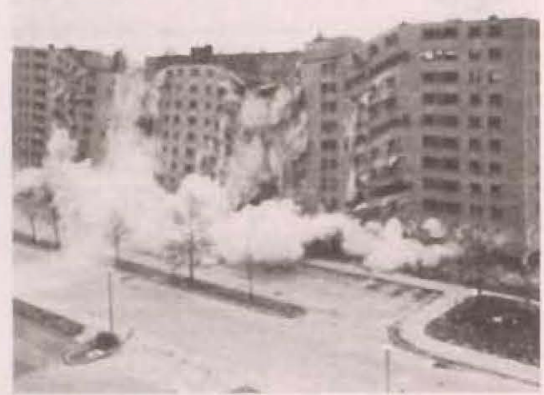

Figure 3.02. Pruitt-Igoe Housing Development, St. Louis. From: pomo2009. wordpress.com

Chicago's Cabrini-Green public housing project is notorious in the United States for being the most impoverished and crime-ridden public housing development ever built. Originally established as inexpensive housing in the 1940's, it soon became a vast complex of unsightly concrete low and high-rise apartment structures (see figure 3.00). As it was left to deteriorate, Cabrini-Green harbored drug dealers, gangs and prostitution. The Chicago Housing Authority (CHA) has since been demolishing the monolithic concrete high-rise slums, replacing them with public housing aimed at not repeating the mistakes of the past.

The architecture of Cabrini-Green played a role in the inevitable doom of the project. City officials felt that the renowned architect LeCorbusier's [radiant city] concept of an urban community, where giant high-rises grew from the ground with enormous green space in between, would be good for public housing. In reality, the green space separated the projects from the rest of the city, concentrating slums into [massive] concrete structures that quickly fell into disrepair.

The 1954 Pruitt-Igoe housing project in St. Louis, Missouri shared a similar fate to that of Cabrini-Green. It was designed on a fifty-seven-acre lot, with thirty-three buildings of concrete slab construction at eleven stories each. In 1974, just twenty years after it was built, Pruitt-Igoe was leveled by the government (see figure 3.02).

CHA experienced great difficulty with this type of building design, ranging from problems with heating systems to frequent elevator failures. Design flaws, coupled with a lack of maintenance and limited capital improvements since initial construction, have rendered these buildings vulnerable to system failures, particularly during winter months.

(Jones, P., 2005) 
Residents have worked extensively throughout the project's history; yet, despite their efforts, there is a certain negative attitude towards the community. Much of this is a result of the stigma of Regent Park as a ghetto of marginalized people warehoused in run-down buildings, with derelict cars and unattended, unsafe public areas (see figure 3.01). The problems with crime, in particular drugs and prostitution, have been identified as often perpetrated by those living outside the neighbourhood. The physical design creates isolated areas that are conducive to these transactions (see figures 3.03 and 3.04).

Since construction in 1948 , there have been no major renovations or changes to the building facades. Building maintenance costs are escalating as a result of current deterioration. In 1989, operating expenses were rapidly approaching four times those for comparable units in the private sector. The operating costs increased 22.7 percent, from $\$ 1,023,774$ in 1987 to $\$ 1,256,000$ in 1989 (Collins, S., 1996).

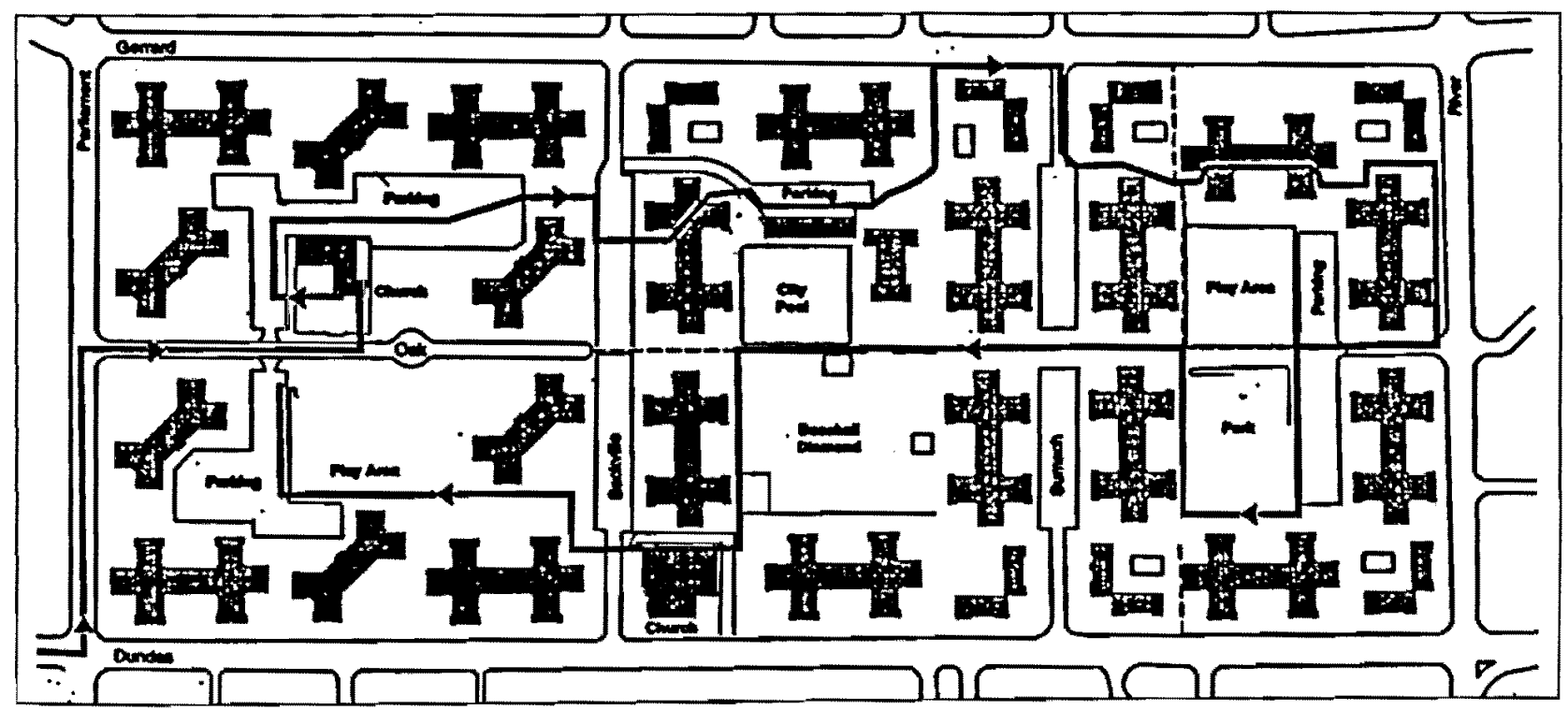

Figure 3.03. Regent Park North, Building Layout, 1950. From: Collins, S., 1996, Urban redevelopment principles: a case study of Regent Park, p.22. 
Regent Park North: Problems Related to Existing Open Space

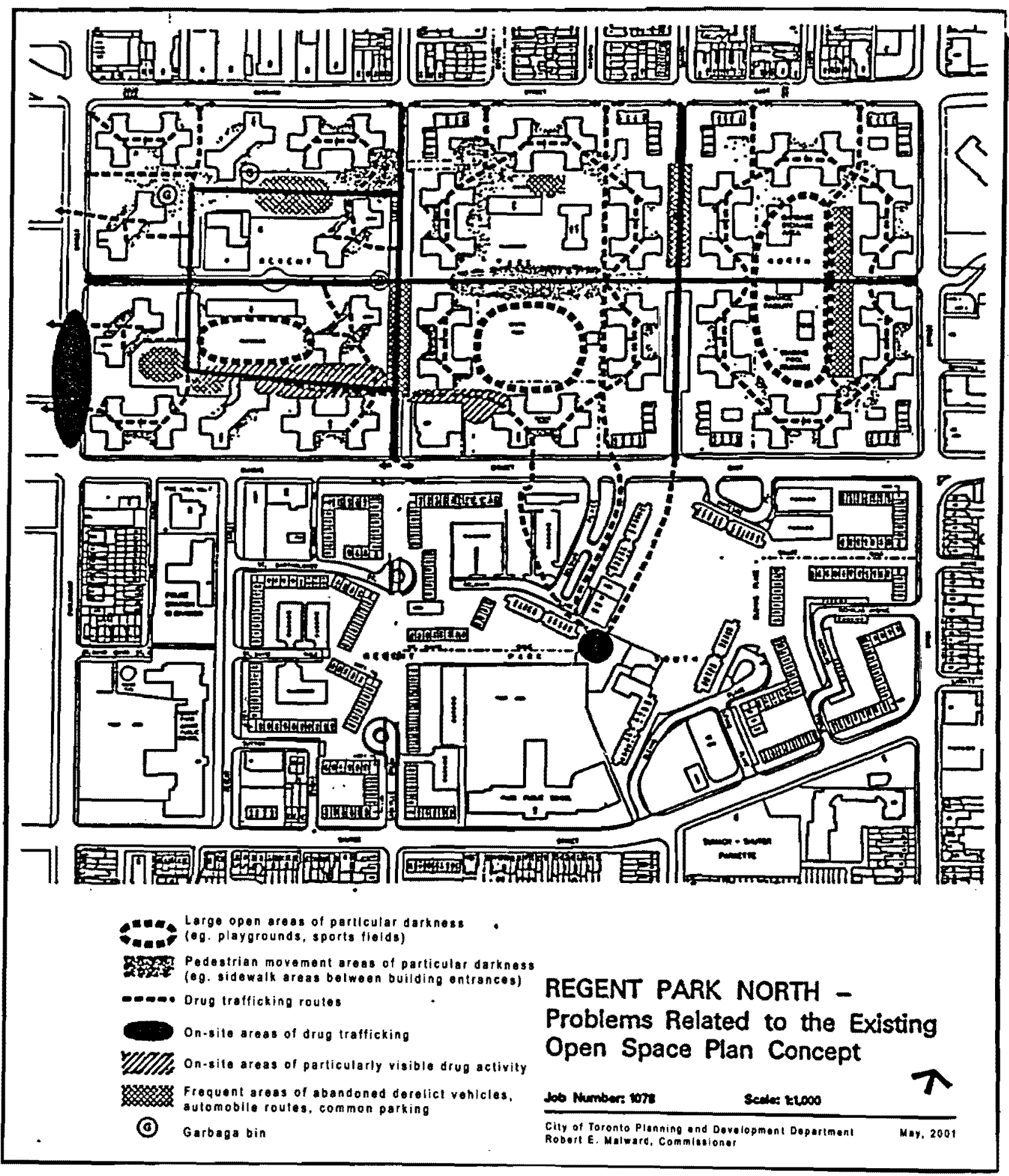

Figure 3.04. Regent Park North: Problems Related to Existing Open Space. From: Collins, S., 1996, Urban redevelopment principles: a case study of Regent Park, p.22. 
Regent Park has been the subject of a number of previous discussions over the past two decades regarding revitalization. The age, condition and configuration of the buildings have contributed to this interest. However, for a variety of reasons, these previous attempts did not succeed. The recent transfer of responsibility for assisted housing, from the Province to the City of Toronto's TCHC, offers a fresh opportunity to re-examine the possibility of redevelopment and regeneration. The proposed plan for Regent Park reintroduces to a large extent the original street network, connecting the new neighbourhood closely with its surrounding neighbourhoods. The street network will re-open all of the earlier streets in the area, such as Sackville, Sumach, Oak and St. David's and add new streets to create a finer grained pattern of blocks. The new pattern provides greater permeability, while creating development flexibility for a variety of building types and heights to create a diverse neighbourhood (see figure 3.05). (Regent Park Revitalization Study, 2002, p. 1).

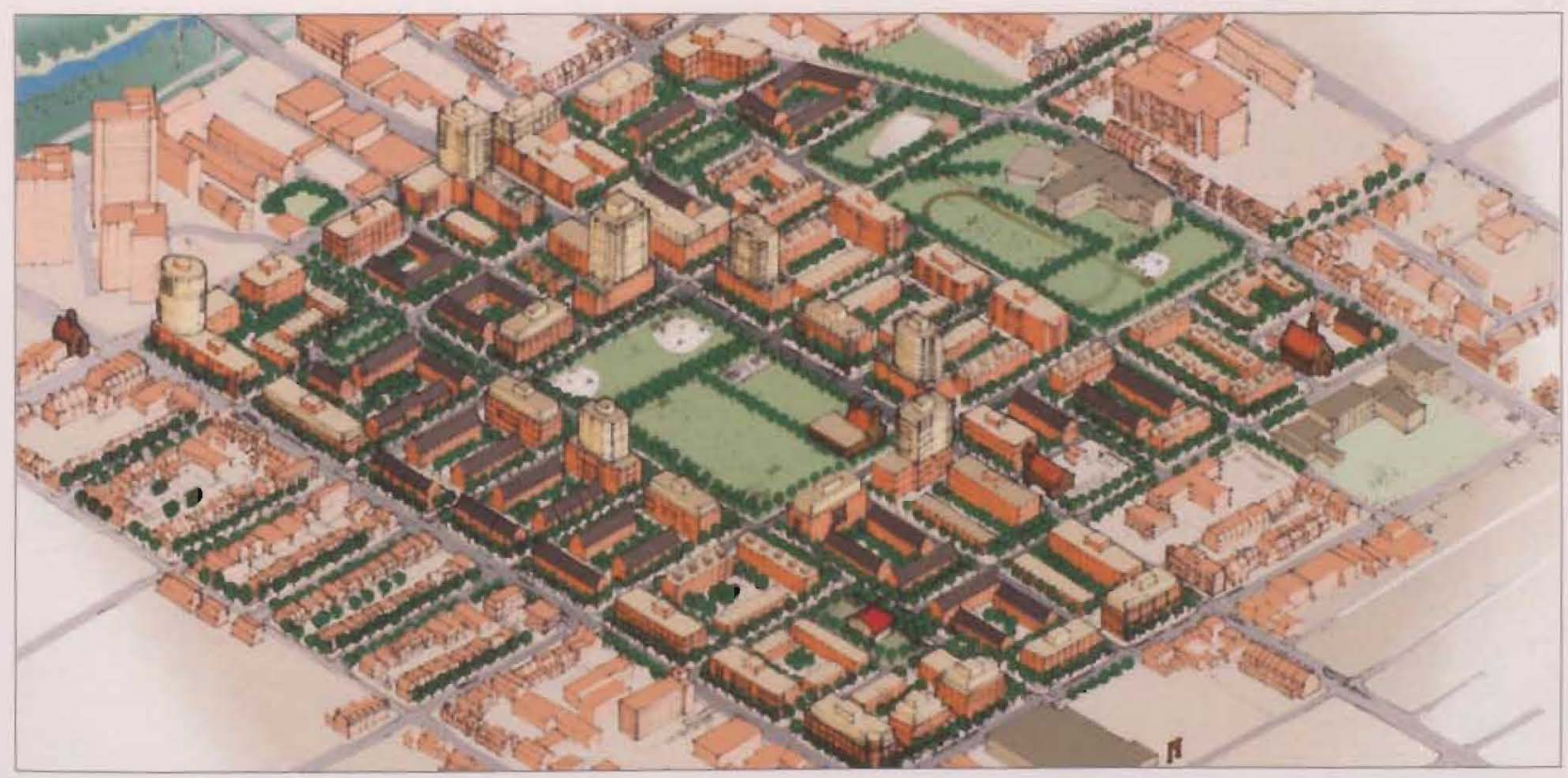

Figure 3.05. Regent Park Revitalization Plan (Aerial View). From: citynoise.org/article/5887 


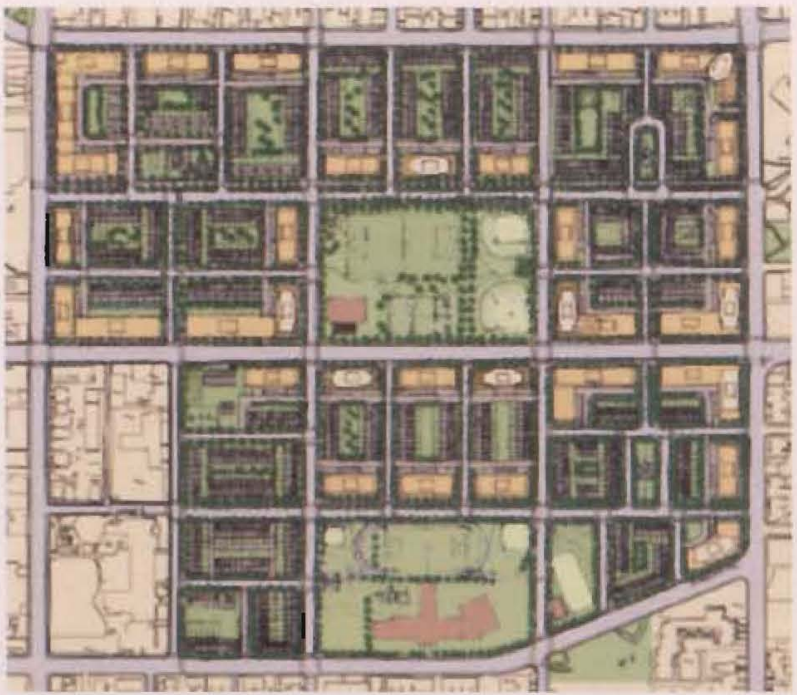

Figure 3.06. Regent Park Revitalization Plan. From: citynoise.org/article/5887

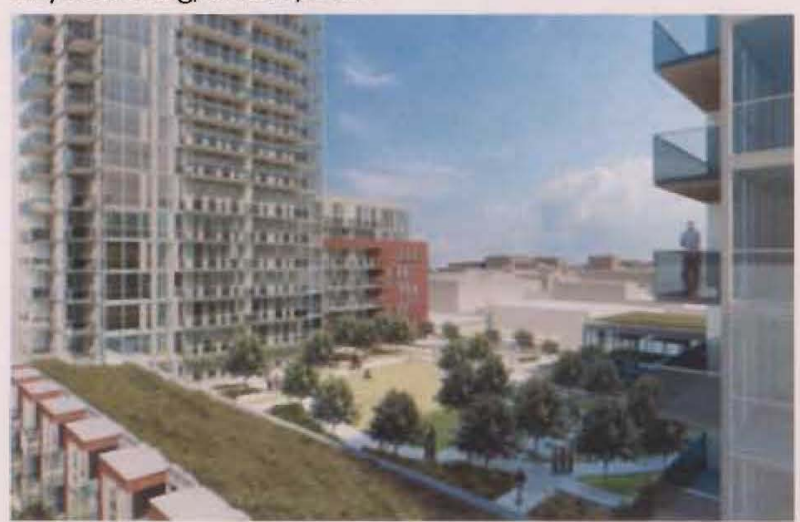

Figure 3.07. Regent Park Revitalization Plan (One Cole Garden). From: onecole.ca/mediaroom2.html

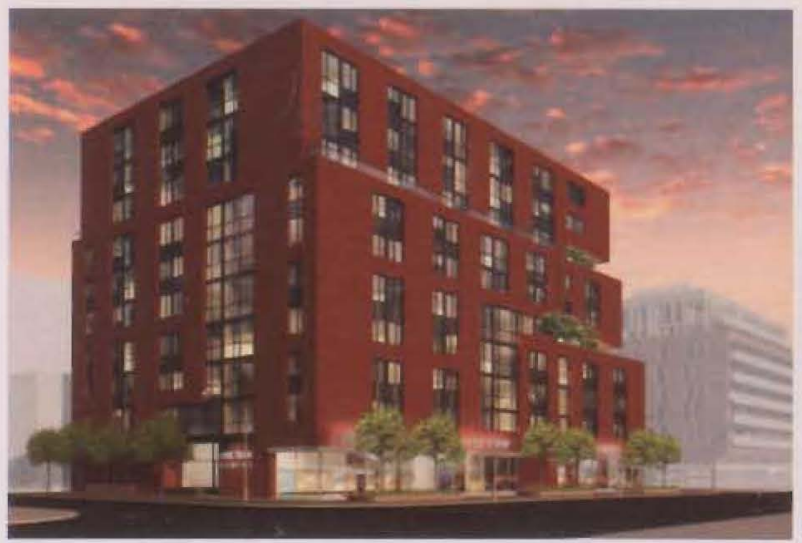

Figure 3.08. Regent Park Revitalization Plan (One Oak Street). From:

torontohousing.ca/investing_buildings/regent_park
The plan proposes a total of 4,500 mixed-income units for the area, compared with 2,087 currently on site. Of the new units, 3,700 are proposed in apartment buildings and 800 are proposed as townhouses. It is assumed that the rent-gearedto-income (RGI) apartment units will be mixed with market units in as many buildings as possible. The plan proposes mixed-use buildings with a wide variety of retail, commercial and institutional uses on the main streets along with different types of housing along the inner, quieter streets. The plan proposes that the Parliament Street retail area be extended south from Gerrard Street and that additional convenience stores be located throughout the area (see figures 3.06, 3.07, 3.08, and 3.09). (Regent Park Revitalization Study, 2002, p. 2).

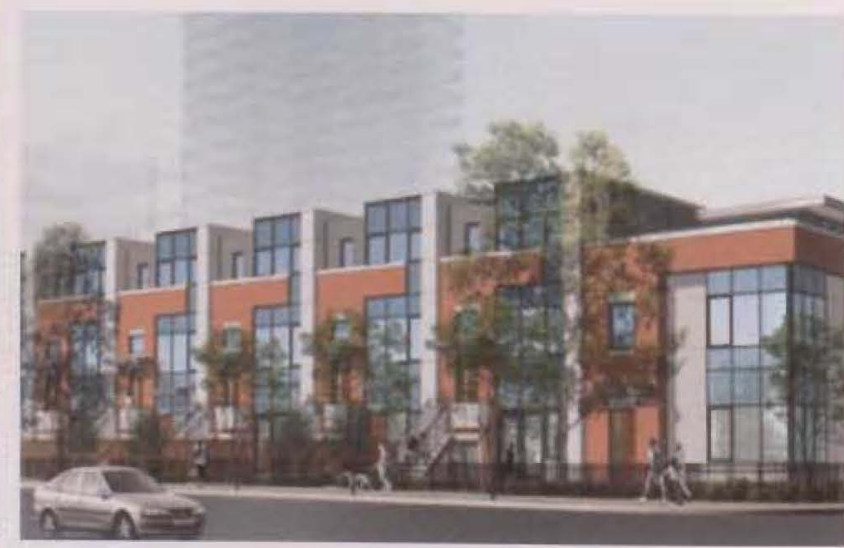

Figure 3.09. Regent Park Revitalization Plan (Townhouses). From: torontohousing.ca/investing_buildings/regent_park 


\section{Case Studies: A Precedent Review of Existing Alternatives}

The following projects represent some examples of sustainable social-housing projects around the world. As we enter an era of environmental awareness, it becomes increasingly important that all building typologies take on a sustainable character, including social housing.

\section{Tetris Apartments - Slovenia}

Tetris Apartments I Ljubljana, Slovenia I Ofis Architects I Built-2005-2007

The first project we'll look at is the Tetris Apartments designed by Slovenian architects Ofis. Tetris was named after the popular Tetris video game, based on the physical nature of the project's design (see figure 3.10).

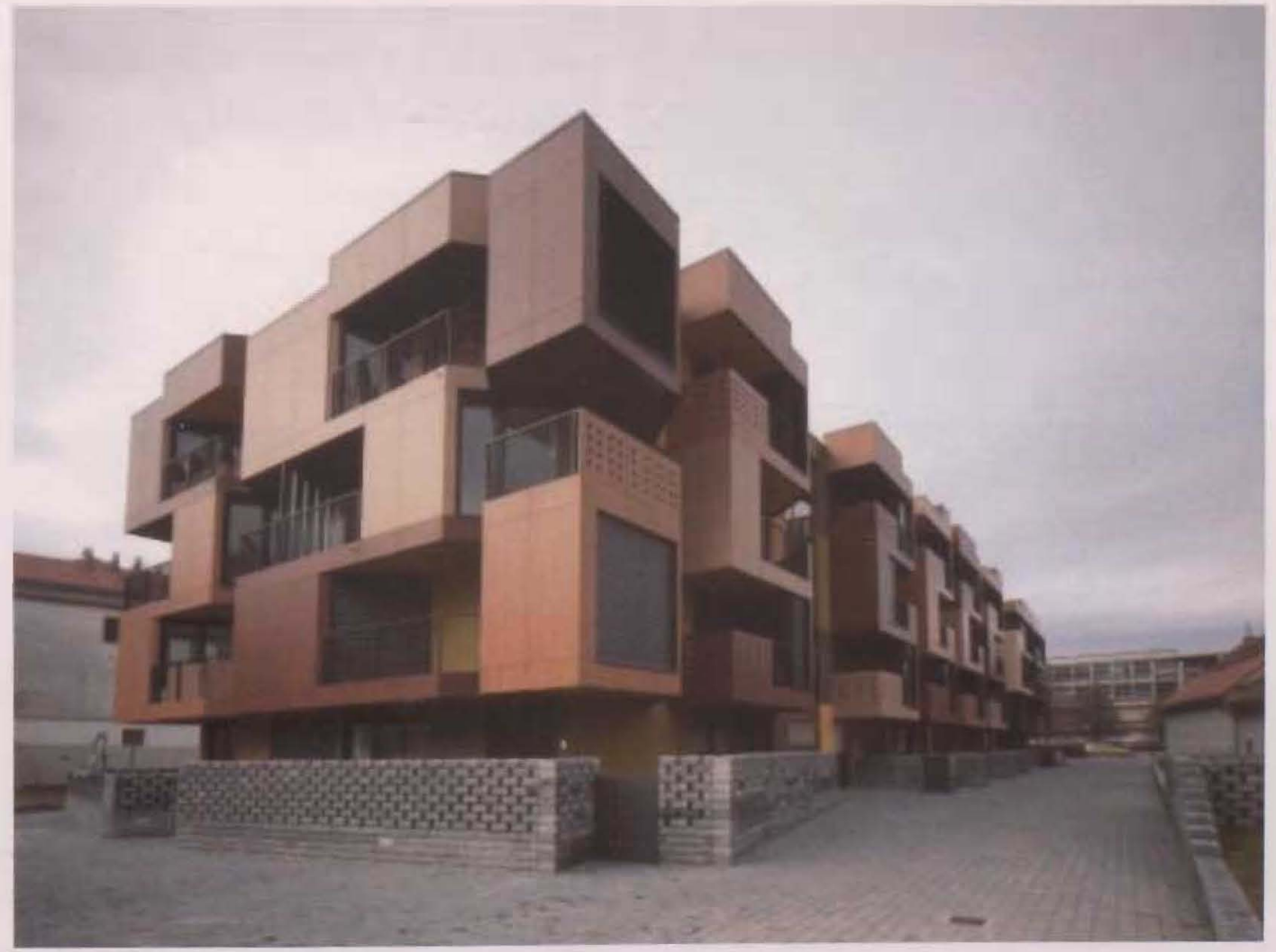

Figure 3.10. Tetris Apartments (Perspective View). From: ofis-a.si/default.cfm 


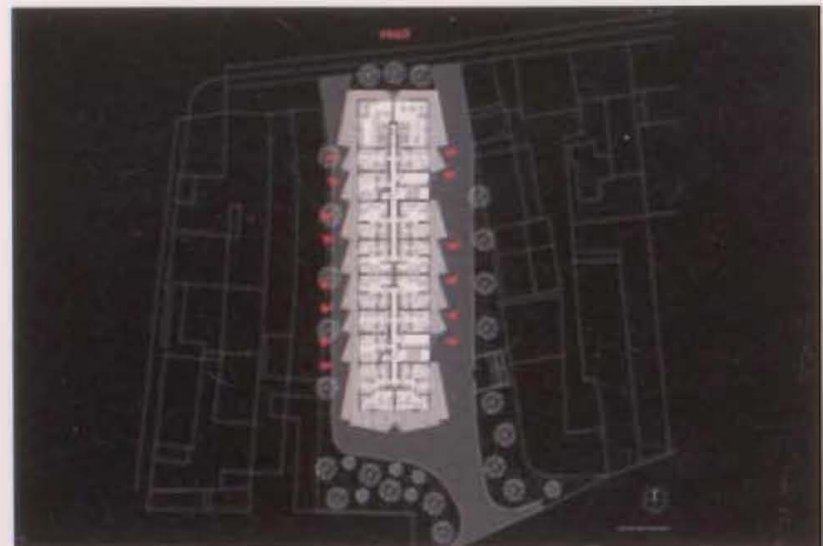

Figure 3.11. Tetris Apartments (Site Plan). From: ofis-a.si/default.cfm

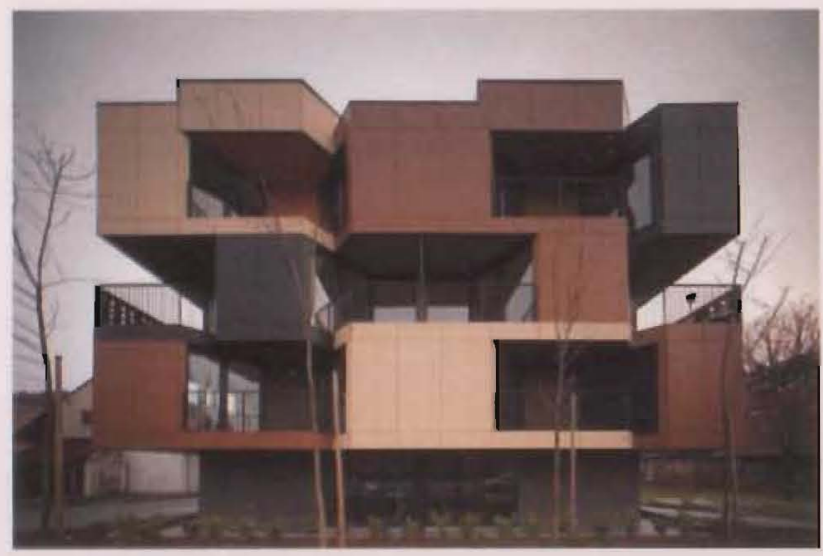

Figure 3.12. Tetris Apartments (North Elevation). From: ofis-a.si/default.cfm

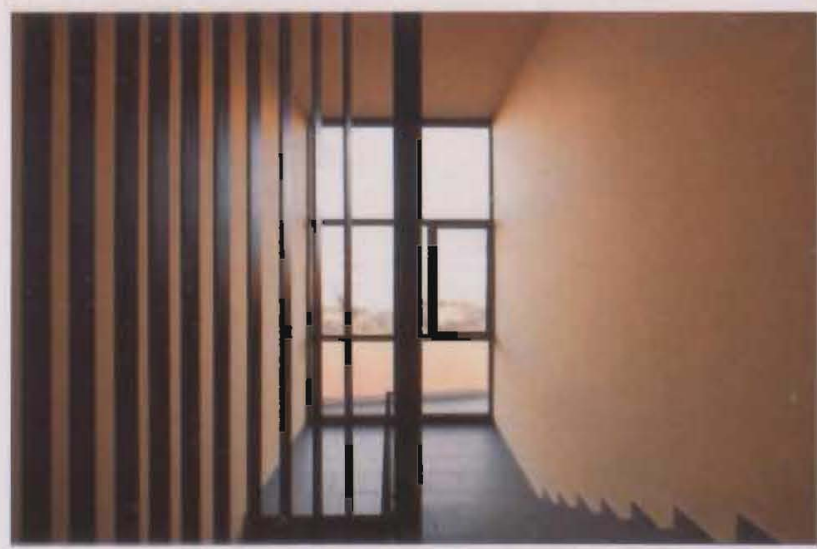

Figure 3.13. Tetris Apartments (Interior View). From: ofis-a.si/default.cfm
This apartment block is of the social type and was sold to the Slovenian Housing Fund. The cost per square meter had to be $650 \mathrm{EUR} / \mathrm{m} 2$ since the selling cost was $1200 E U R / m 2$.

\section{Sustainability issues:}

The combination of balconies and winter gardens functions as a constant temperature buffer zone to the main living and sleeping areas. (See figures 3.11 and 3.12) The balconies are positioned away from the busy road. At the same time, they provide shelter from direct sunlight. (See figures 3.13 and 3.14). The service and communication spaces are reduced to a minimum, thus the daylight is provided on the shafts. The monthly basic energy and service costs are very low; so they're also economic for the habitants since the apartments are social housing (Ofis, 2008; revised for clarity).

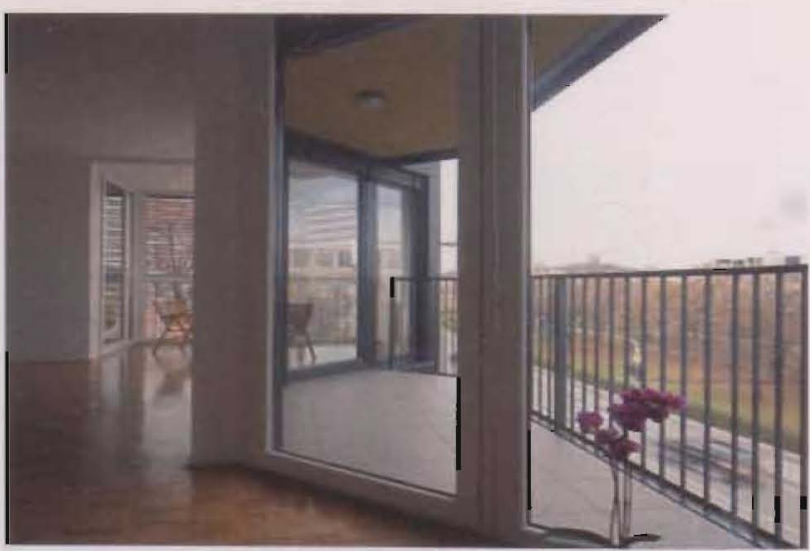

Figure 3.14. Tetris Apartments (Patio View). From: ofis-a.si/default.cfm 


\section{Pajaro - California}

Pajaro I Davis, California | Sam Davis Architects | Built - 1981

Pajaro is the evolution of a larger, fully market-rate project called Summertree, which was a Progressive Architecture award winner. Reduced in size from 144 units to 36, then redesigned to make half the units affordable, as required by local inclusionary zoning, Pajaro was intended as an alternative to suburban single-family detached housing for either 'empty nesters' or first time buyers and as a demonstration of several energy-conserving features. The developers owned the active solar-energy system that provided hot water, space heating, and some cooling for the units, and Pajaro was their first project that displayed how the system could be architecturally integrated into multi-family housing (Davis, 1995, pp. 162-163).

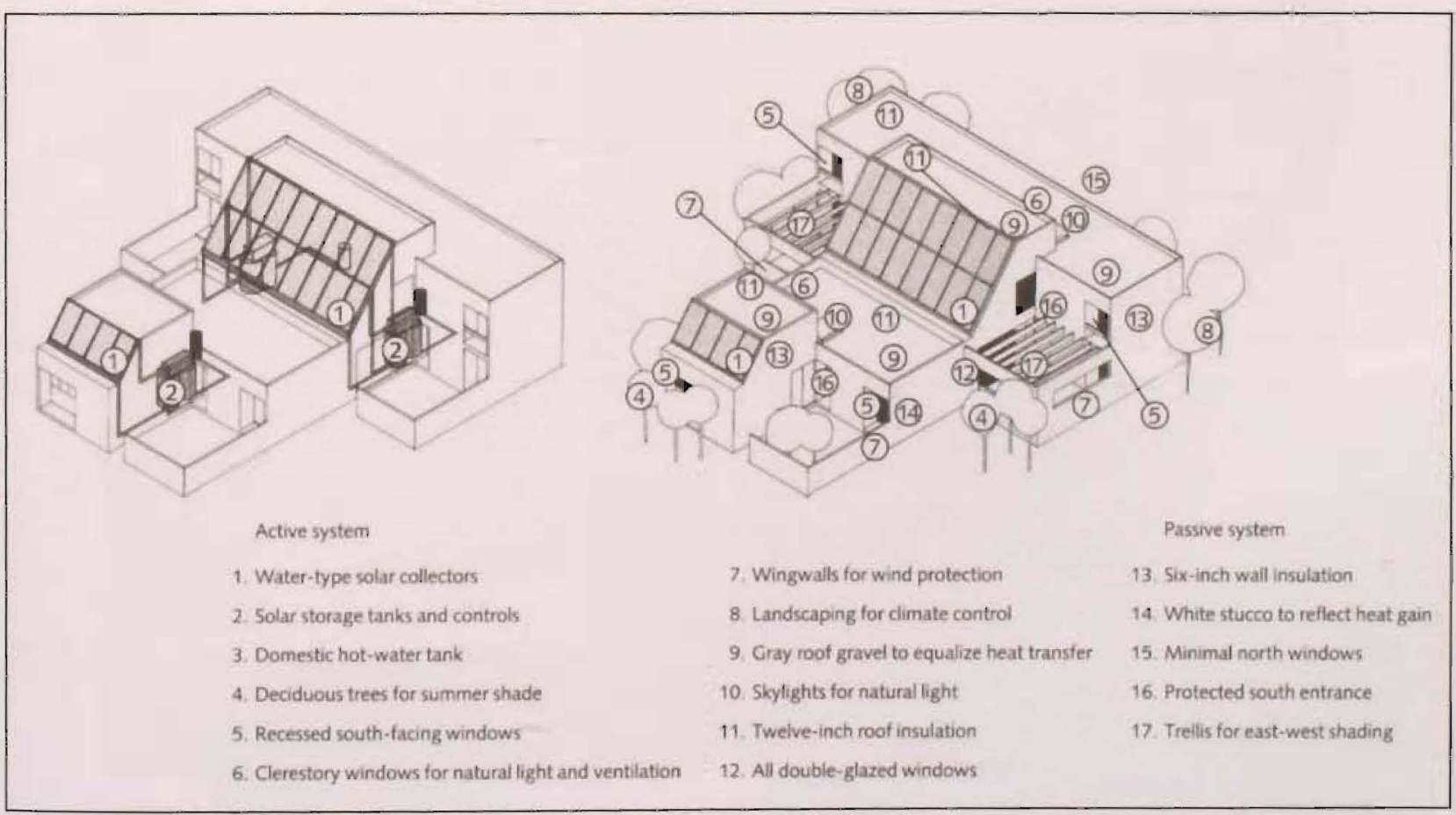

Figure 3.15. Pajaro (Active \& Passive Systems). From: Davis, S., 1995, The architecture of affordable housing, p. 167 


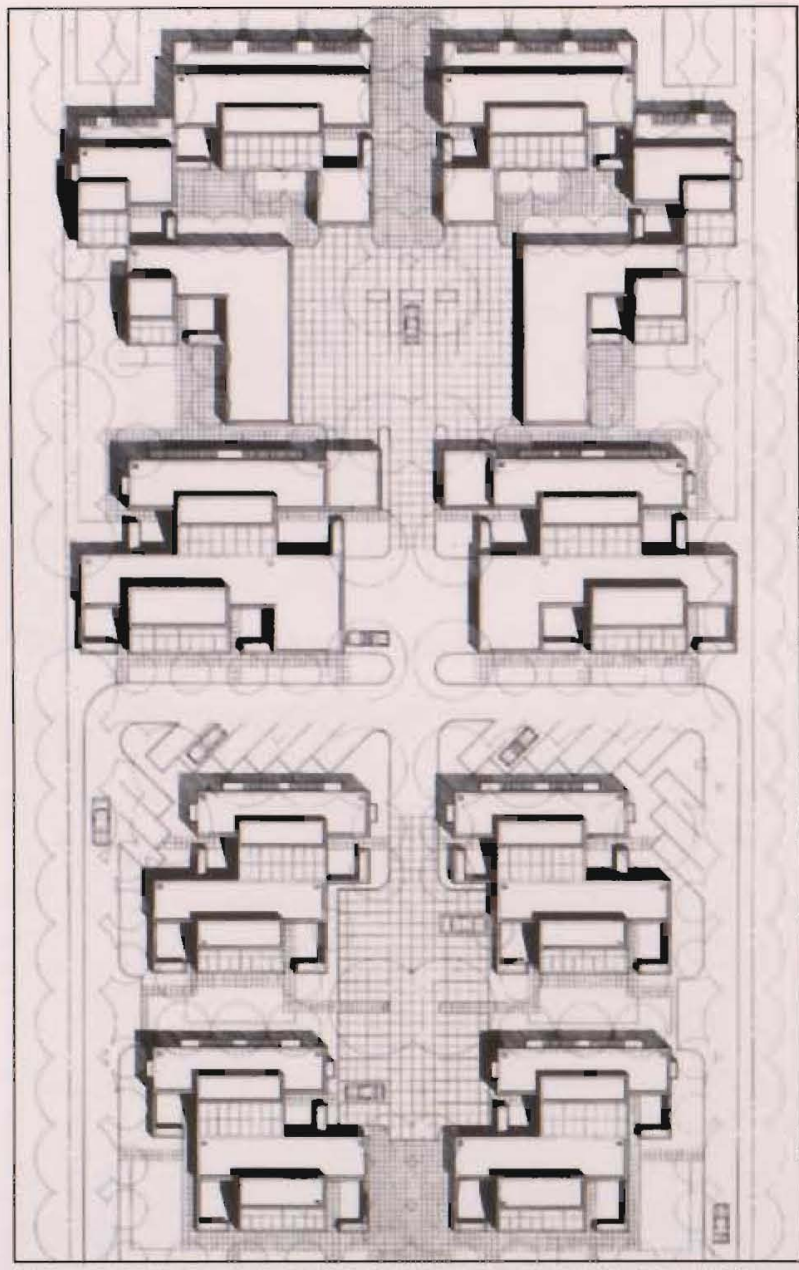

Figure 3.16. Pajaro (Site Plan). From: Davis, S., 1995, The architecture of affordable housing, pp. 162

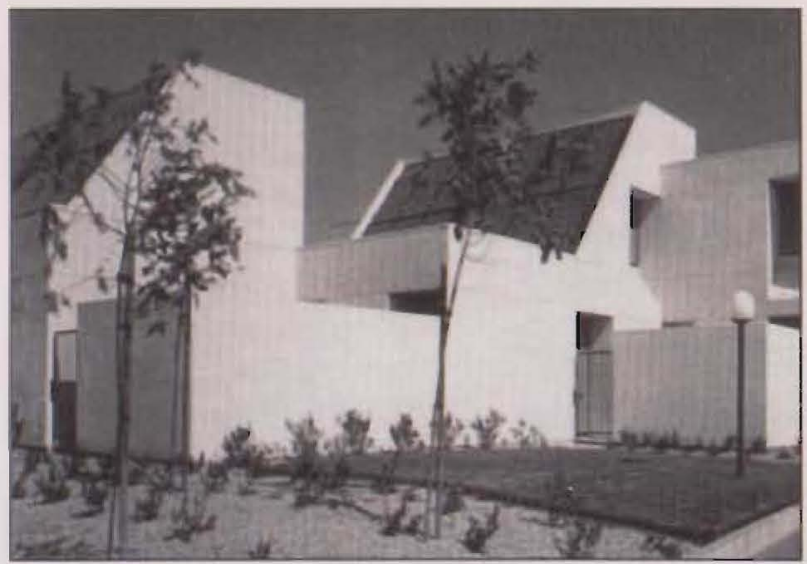

Figure 3.17. Pajaro (Perspective View). From: Davis, S., 1995, The architecture of affordable housing, pp. 163
These two agendas, the energy imperative and the higher-density alternative to the house, had a dramatic impact on the design. The planning strategy entailed taking a single house form with a square plan and a corner patio, mirroring it, and attaching the two. The resulting two-unit building was then staggered with another, similar combination, making four connected dwellings. Four such clusters were formed around a courtyard, which became a corral for cars close to each house. To make this an attractive alternative to the detached dwelling for the market-rate buyers, many house features were retained. For example, each dwelling is self-contained, with its own solar-energy system and its own private, enclosed patio that serves as both entry and yard (Davis, 1995, p. 163). (See figures $3.16,3.17$, and 3.18 )

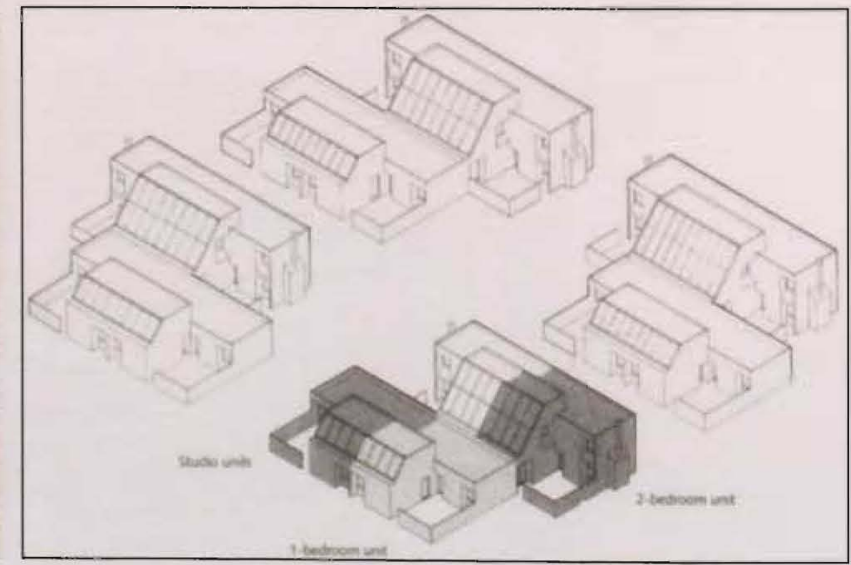

Figure 3.18. Pajaro (Permutations). From: Davis, S., 1995, The architecture of affordable housing, pp. 165 


\section{Ocho casas inscritas y tres patios - Spain}

Ocho casas inscritas y tres patios I Santa Margarita, Spain I Romera y Ruiz Arquitectos

The main goal of this project was to reduce the natural resource consumption of an apartment block without impacting the comfort of its residents. To do so, the project maximizes the environmental performance of the building. It comes equipped with a water collection and reuse system, is constructed of low or non-toxic materials, and it incorporates smart building practices that require less resources for its construction and ongoing maintenance. (See figure 3.19).

Social housing and sustainable design are two concepts that are, sadly, seldom combined. The Ocho Casas complex proves that affordable green housing can change our neighbourhoods for the better, and we are glad to see inspired and beautifully executed projects such as this (Inhabitat, 2008).
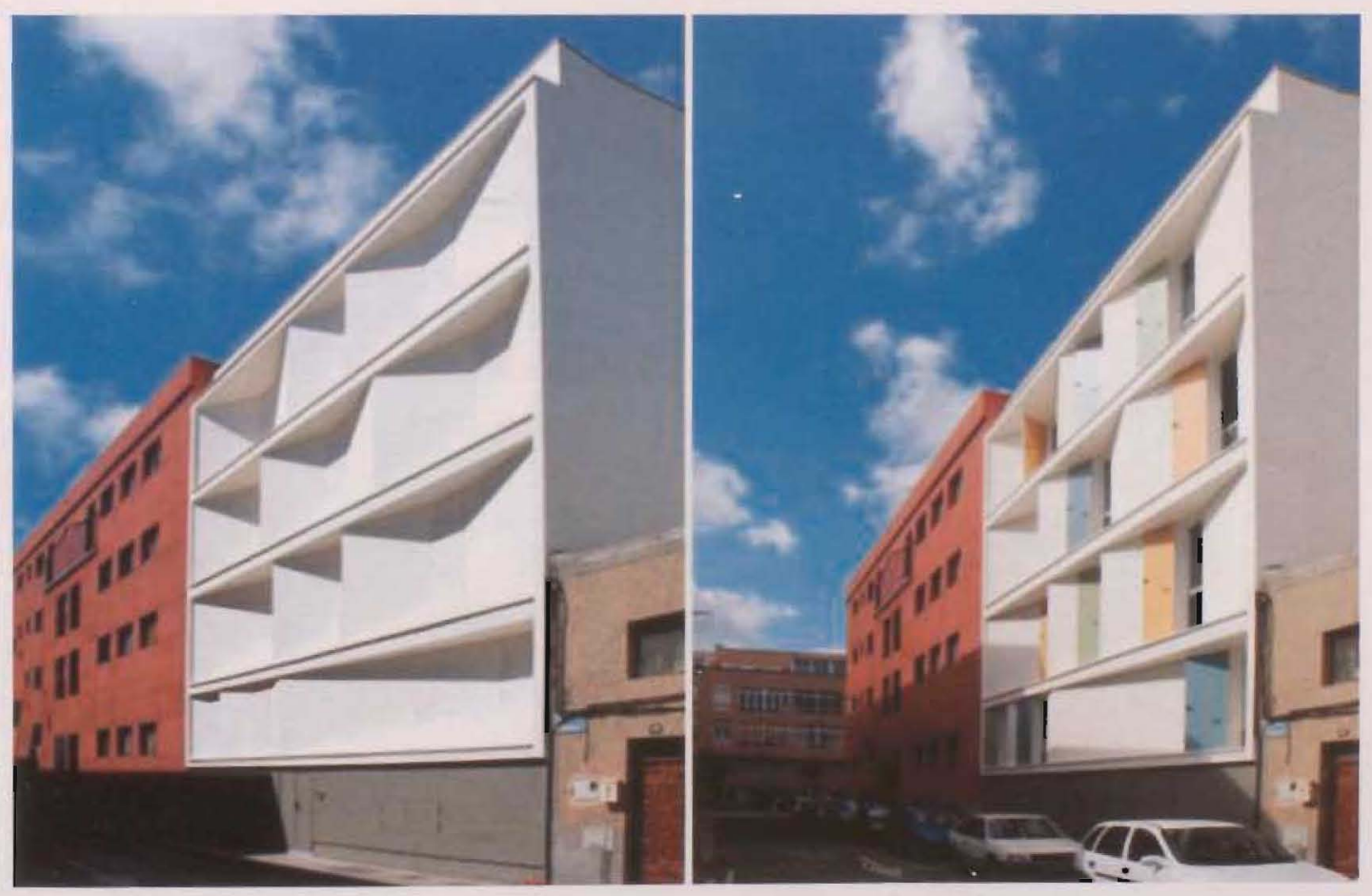

Figure 3.19. Ocho casas inscritas y tres patios (Façade Permutations). From: inhabitat.com/2008/11/17/origami-inspired-social-housing/ 


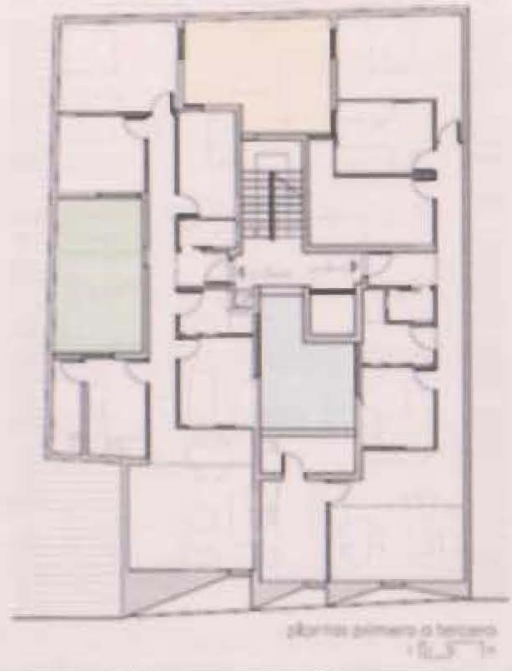

Figure 3.20. Ocho casas inscritas y tres patios (First Floor Plan). From:

inhabitat.com/2008/11/17/origami-inspired-socialhousing/

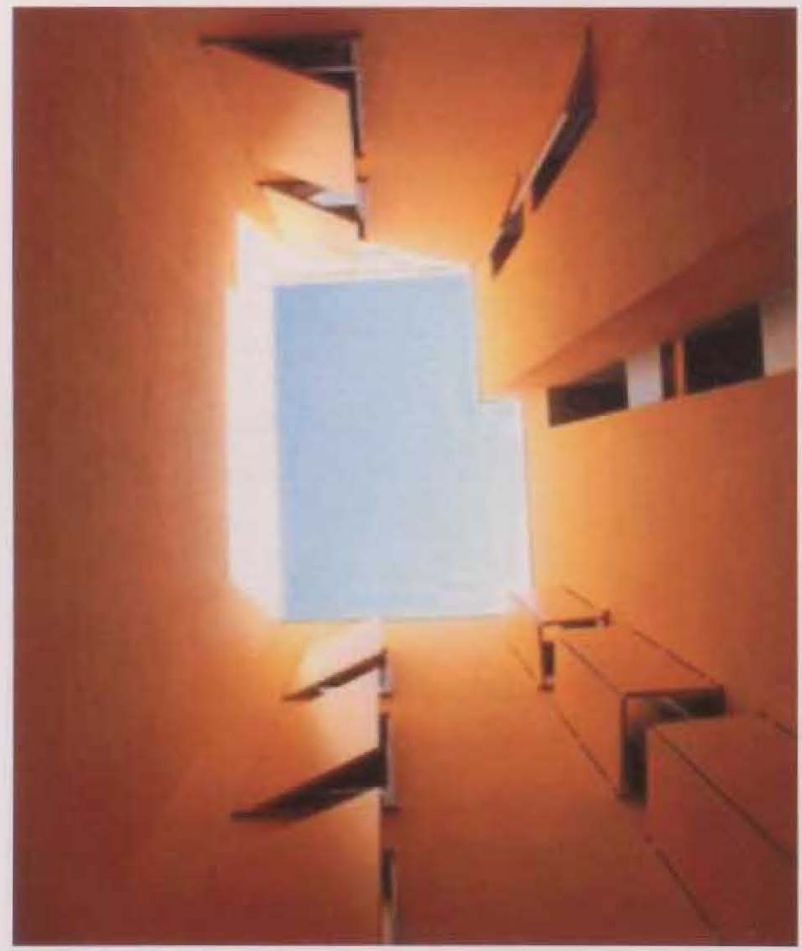

Figure 3.21. Ocho casas inscritas y tres patios (Lightwell). From:

inhabitat.com/2008/11/17/origami-inspired-socialhousing/
Frequent passerbys in the neighborhood of

Santa Margarita, Spain may find themselves a bit lost when they can't seem to find the white wall they just passed by. Appearing at first as a simple sheet of folded paper, this beautiful white-walled building features a facade of panels that open in brilliant pops of color. 'Ocho casas inscritas y tres patios' is a sustainably constructed social housing complex with a facade that changes according to the wishes of its inhabitants. This project was nominated as a finalist at the World Architecture Festival recently held in Barcelona. The name translates to 'Eight inscribed houses and three courtyards', referring to the unique geometry of the building, which essentially allows each unit to share one of the three courtyards within (Inhabitat, 2008). (See figures $3.20,3.21$, and 3.22 )

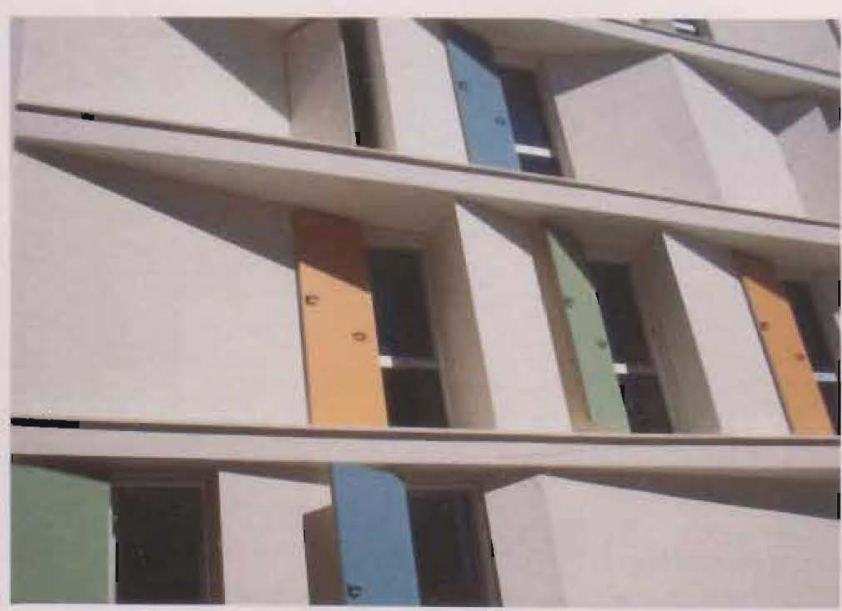

Figure 3.22. Ocho casas inscritas y tres patios (Building Facade). From: inhabitat.com/2008/11/17/origami-inspired-socialhousing/ 


\section{Summary}

The history of social housing in Canada demonstrates a distinct transition from fully concentrated towers of despair to relatively improved socially mixed neighbourhoods. This significant shift in the way of thinking is also inherent in models around the world, in countries such as Spain, America, and Slovenia. It has become evident that social housing should no longer exist as an isolated entity within an urban fabric but, rather, as an integrated system of mixed housing developments as a continuation of a broader community. Figure 3.23 attempts to graphically outline the elements that have become normative characteristics of social-housing design. These elements - mixed use, mixed income and sustainability, for example - should be used as a minimum platform for moving forward in the future design of integrated communities. These design elements will necessarily vary based on such conditions as the location, culture (end user), and surrounding area of a specific site and community application.

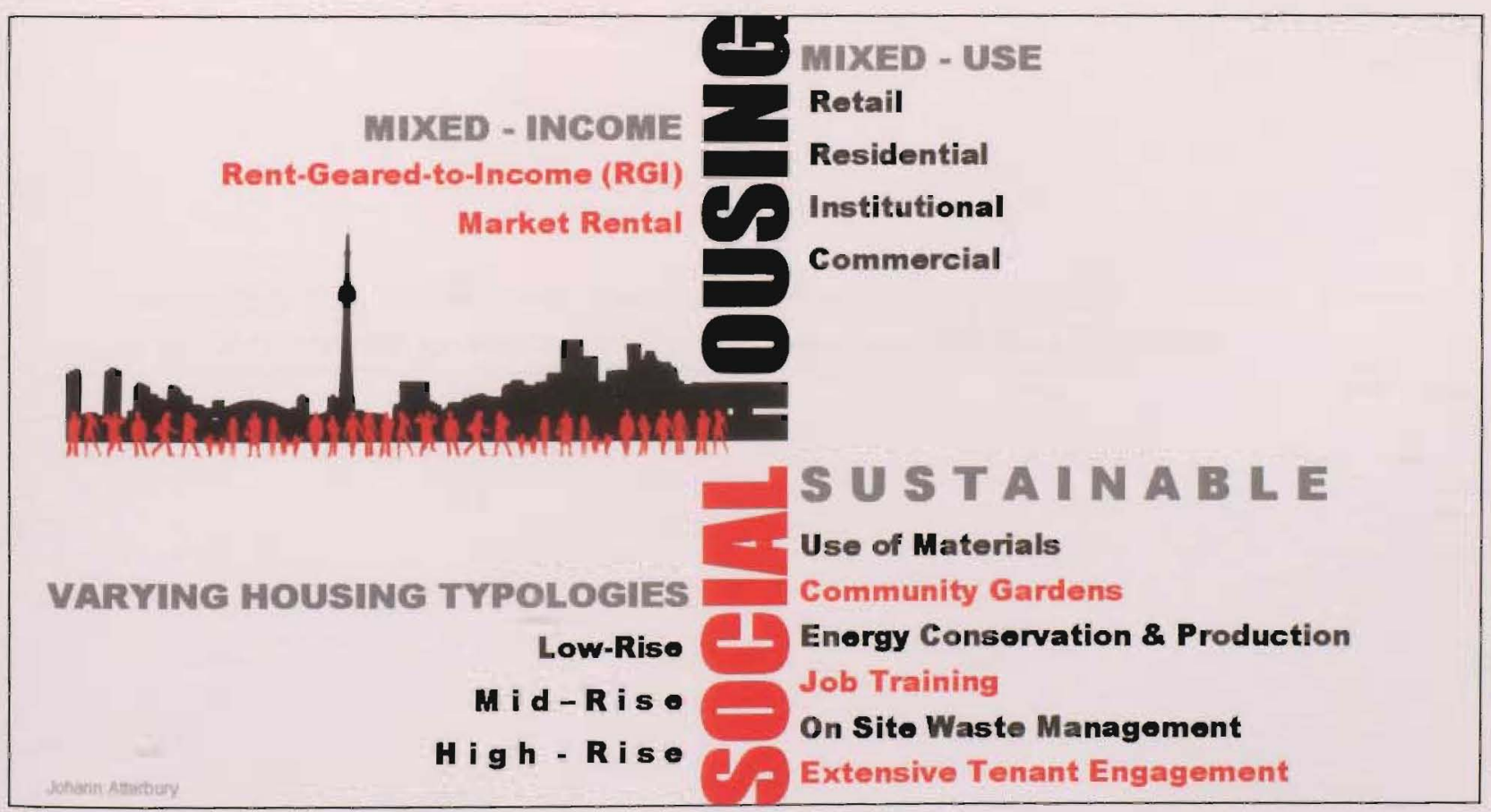

Figure 3.23. Present-day elements of social housing design. 


\section{Design}

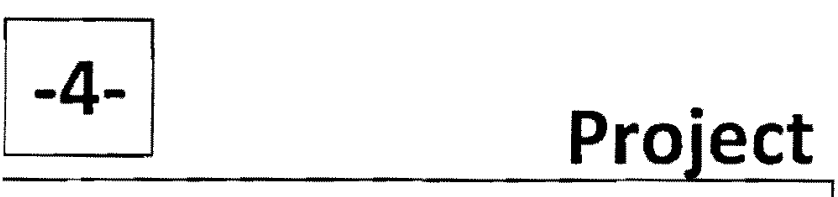

"If we believe that architecture serves a society as well as reflects its values, then we must use it to provide for those with the most need and the fewest options." 

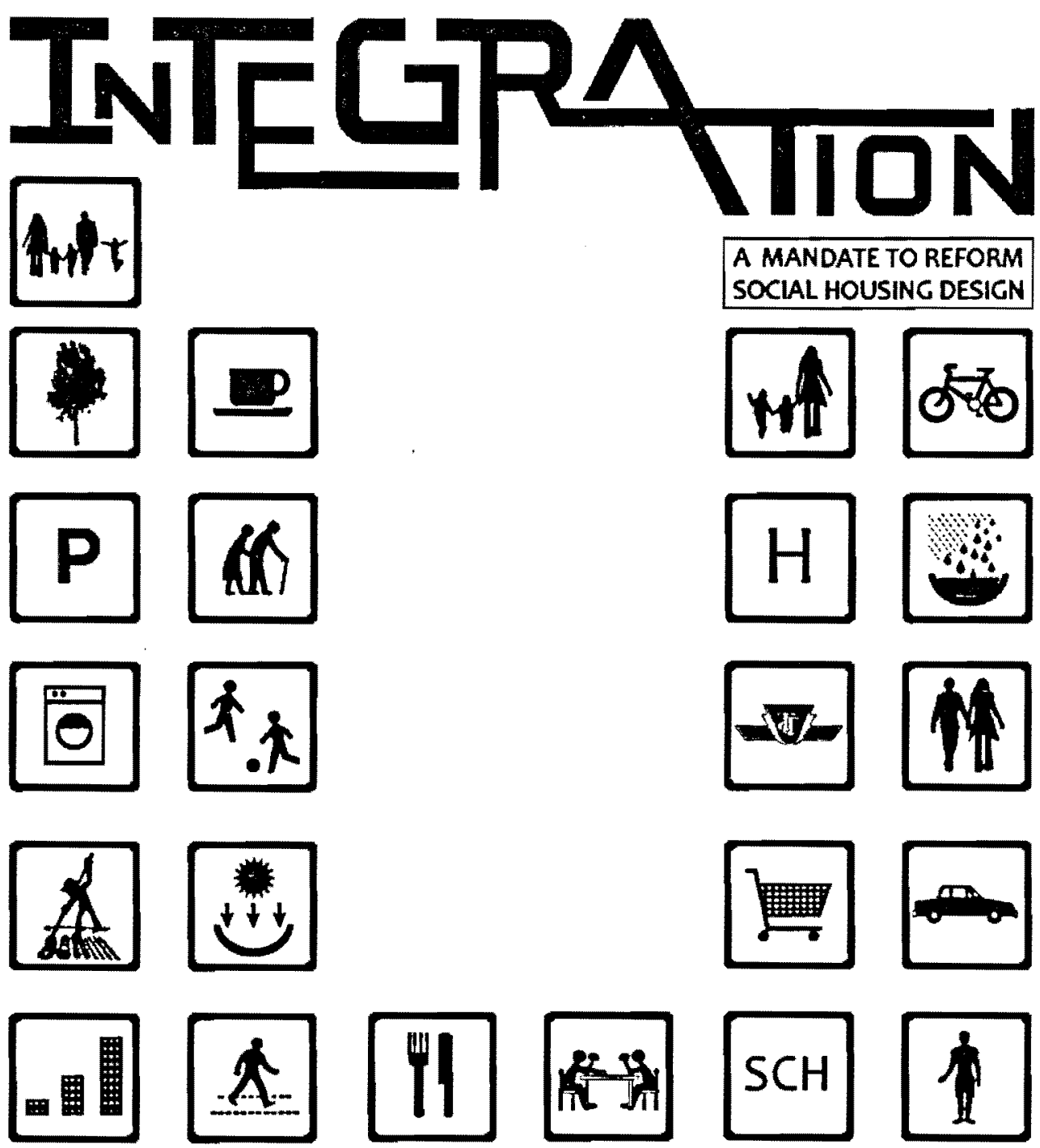

Figure 4.00. Elements characteristic of integrated neighbourhoods 


\section{Integration: A Mandate to Reform Social Housing Design}

\section{Overview}

Social housing has too often been an easily identifiable insertion into an urban community fabric. Whether it be the dense, monolithic reflections of the building code or the metal separators that create a clearly defined threshold between market rental and R-G-I (rent-geared-to-income) housing, there is an evident division between the two. This separation led to the creation of isolated communities made up solely of low income individuals. Combined with its impermeable nature, developments, such as Cabrini Green, Regent Park and Pruitt-Igoe were quickly reduced to slums, ghettos, and unsafe neighbourhoods that were segregated from the broader community.

Recent approaches to social housing rejects this design methodology and embraces a more integrative one predicated on the idea of creating mixed communities as an extension or bi-product of a wider urban environment. Examples of this are St. Lawrence neighbourhood (Toronto), and Regent Park's current redevelopment scheme which, as a design mandate, encourages the implementation of mixed-activity spaces, and also maintains the existing, Toronto city street grid (or in the case of Regent Park, re-introduces it) to allow these neighbourhoods to merely become a continuation of the surrounding urban fabric.

Given all we have seen and experienced with past attempts at social housing design, present "discussion" should focus on a process of designing for 'integrated neighbourhoods' of mixed activity (see figure 4.00). Meaning that our focus should shift from the design of isolated developments to the creation of diverse communities that support a myriad of activities, socio-economic backgrounds, permeability and flexibility. By definition, the term 'integrate' means to make into a whole by bringing all parts together; to unify. This design project drew inspiration from the term 'integration' both as a generator as well as a guiding principle for design. Relating specifically to integrated neighbourhoods, the term has been further broken down into five principles of analysis that can then be used to measure

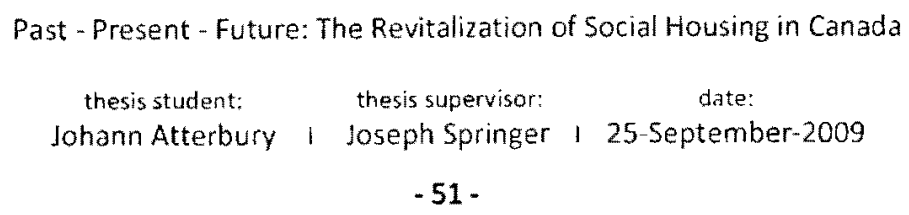


the level of integration of a specific site; integration of movement, integration of open spaces, integration of physical structures, social integration, and integrated sustainable systems (see fig. 4.01).
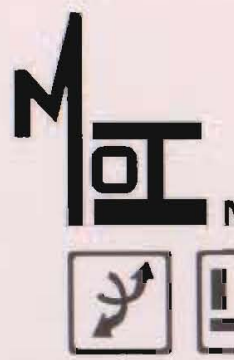

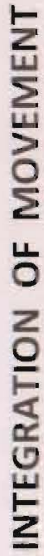
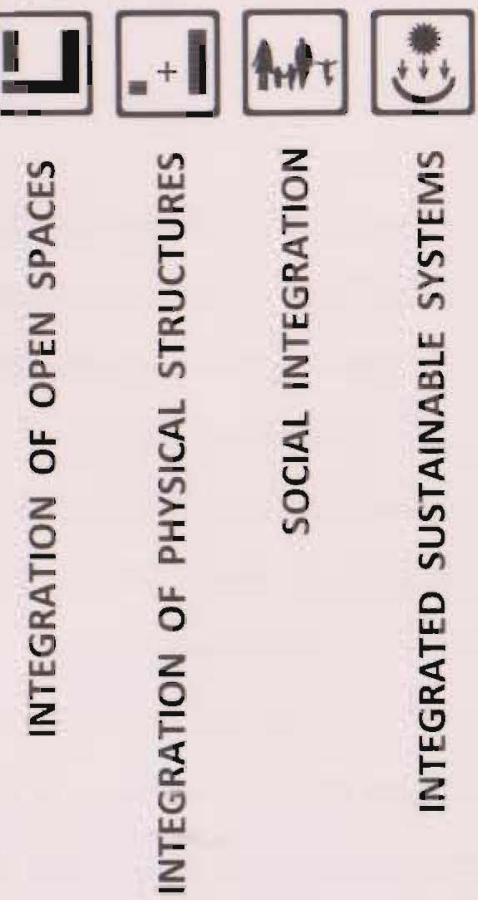

岕

Figure 4.01. Modes of Integration
These 'modes of integration' were used to test the level of connectivity (or lack thereof) that currently exists within a selected low-income housing community of Toronto, Canada. The selected site was evaluated based on this established criterion and a design proposal was developed as a reaction to the findings. Alexandra Park, located in the downtown Toronto area was selected as a candidate for investigation. It is a centrally located development comprising both the Atkinson Housing Co-operative and Toronto Community Housing Corporation (TCHC) buildings. The site is contained within the major streets of Dundas Street West (on the northern end), Spadina Avenue (on the eastern end), Queen Street West (on the southern end), and Bathurst Street (on the western end). See figure 4.02 . Centrally located, more than 2000 residents of Alexandra Park take advantage of surrounding neighbourhood connections and services

such as public transportation, recreational, community and health services (see figures 4.03 to 4.13 ). While this outward link is desirable, the lack of commercial activity within Alexandra Park suggests an asymmetrical level of connectivity.

The existing site conditions are graphically illustrated (see figures 4.14 to 4.27 ), and these were measured against the established 'modes of integration'. Following is the design response which seeks to address some of the issues that arose from this exercise and a comparative data analysis offers a sideby-side review of the areas of eventual intervention. 


\section{Alexandra Park - Site Location \& Analysis}

Composed of both the Atkinson Housing Co-operative and Toronto Community Housing Corporation (TCHC) buildings.

\section{Number of Dwellings}

Site Area

Density

Access to amenities

Parking

Tenure

Average household income

Uses

\section{Building types}

\section{Building heights}

\section{Unit types}

\section{Communal open space}

Private/semi-private open space
806 dwelling units

7.5ha (including parking)

$107 \mathrm{dph}$ (dwellings per hectare)

Residents take advantage of surrounding neighbourhood connections and services such as public transportation, recreational, community, and health services.

290 \# parking spaces

Rented

$\$ 26,771$

Residential

Townhouses and apartments

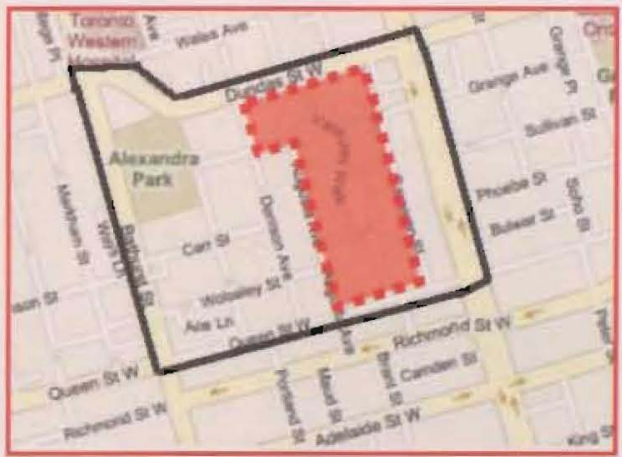

Figure 4.02. Site Location - Alexandra Park, Toronto, Canada. From: www.rapdict.org

Low, mid, and high-rise

3 bedroom units $\left(95 \mathrm{~m}^{2}\right), 5$ bed units $\left(131 \mathrm{~m}^{2}\right)$, and 1 bed units $\left(64 \mathrm{~m}^{2}\right)$

Small, underutilized open spaces

Balconies and small gardens

Figure 4.03. Alexandra Park - Existing Site Data

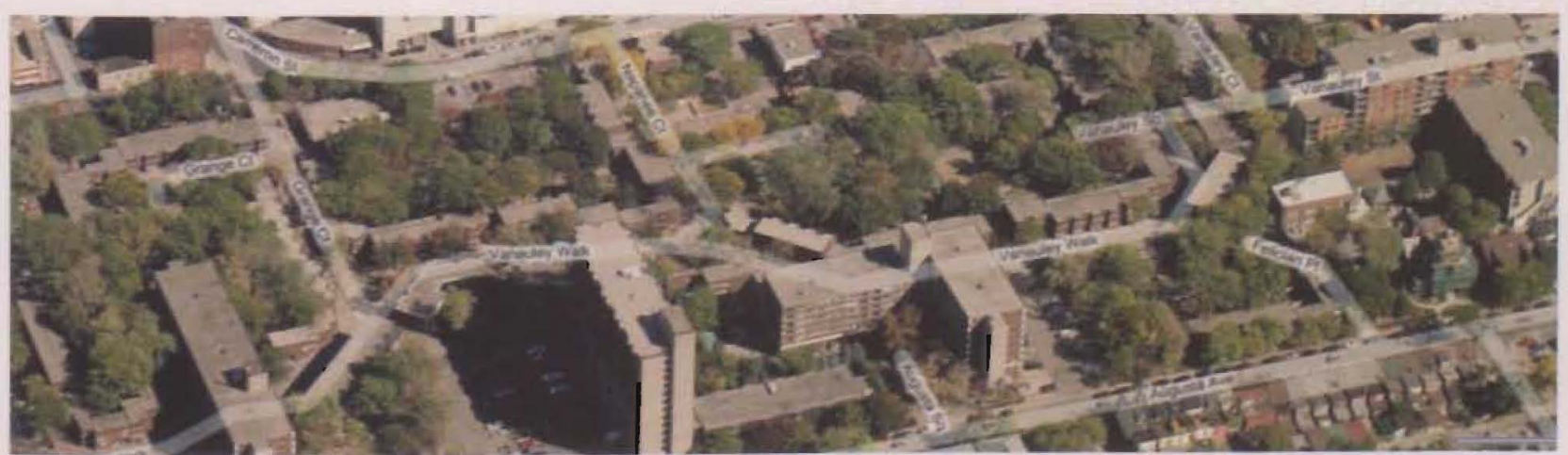

Figure 4.04. Aerial View - Alexandra Park, Toronto, Canada. From: http://www.rapdict.org/Alexandra_Park 


\section{Neighbourhoods surrounding Alexandra Park}

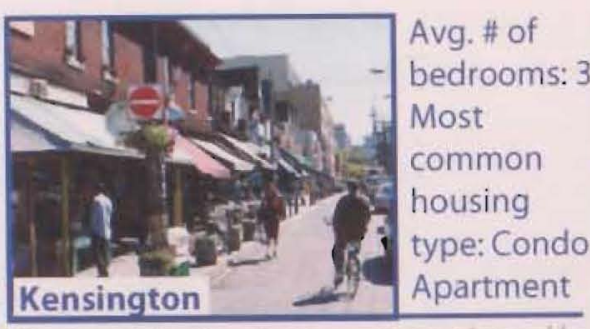

Fiqure 4.05. Kensington. From: http:// www.pps.org

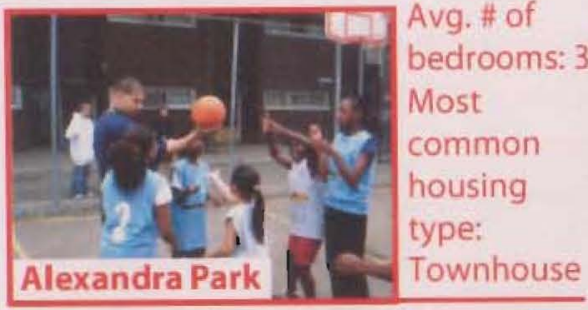

Figure 4.06. Alexandra Park. From: http //www.atkinsonhousingcoop.com

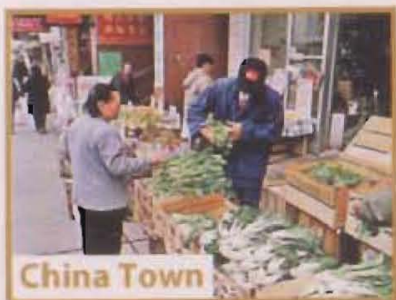

Avg. $\#$ of
bedrooms: 2
Most
common
housing
type: Condo
Apartment

Figure 4.07. China Town. From: http:// www.affordable-cruisestours.com

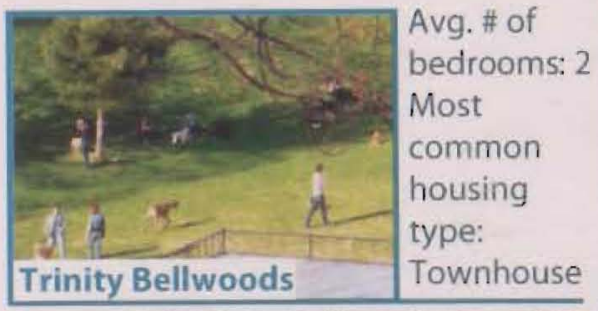

Figure 4.08. Trinity Bellwoods. From:http //tzero.wordpress.com

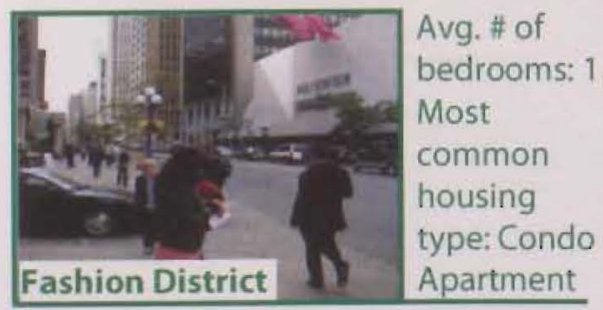

Figure 4.09. Fashion District. From:http:

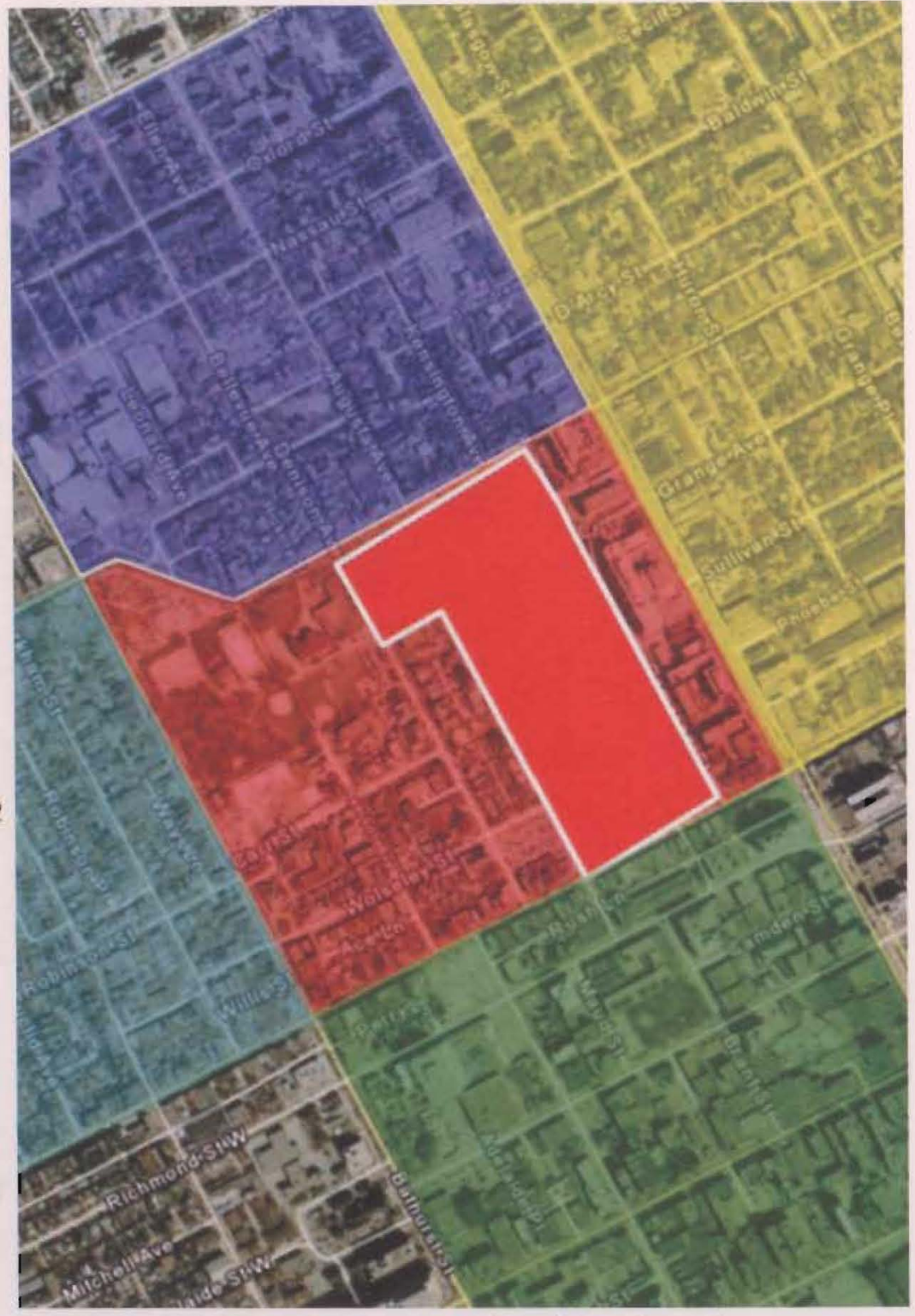

Figure 4.10. Neighbourhoods surrounding Alexandra Park

Trinity-Spadina Federal Electoral District*

Overview

Avg. Household Income: $\$ 69,834.00$ Low

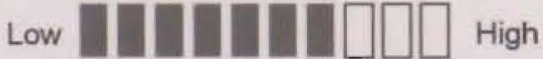

Provincial Average: $2685 \%$

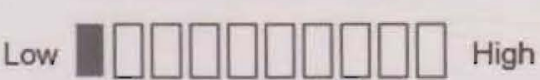

Provincial Average: 1.2

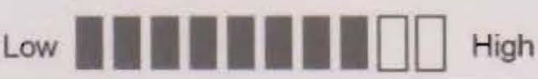

//www.flickr.com

Past - Present - Future: The Revitalization of Social Housing in Canada 


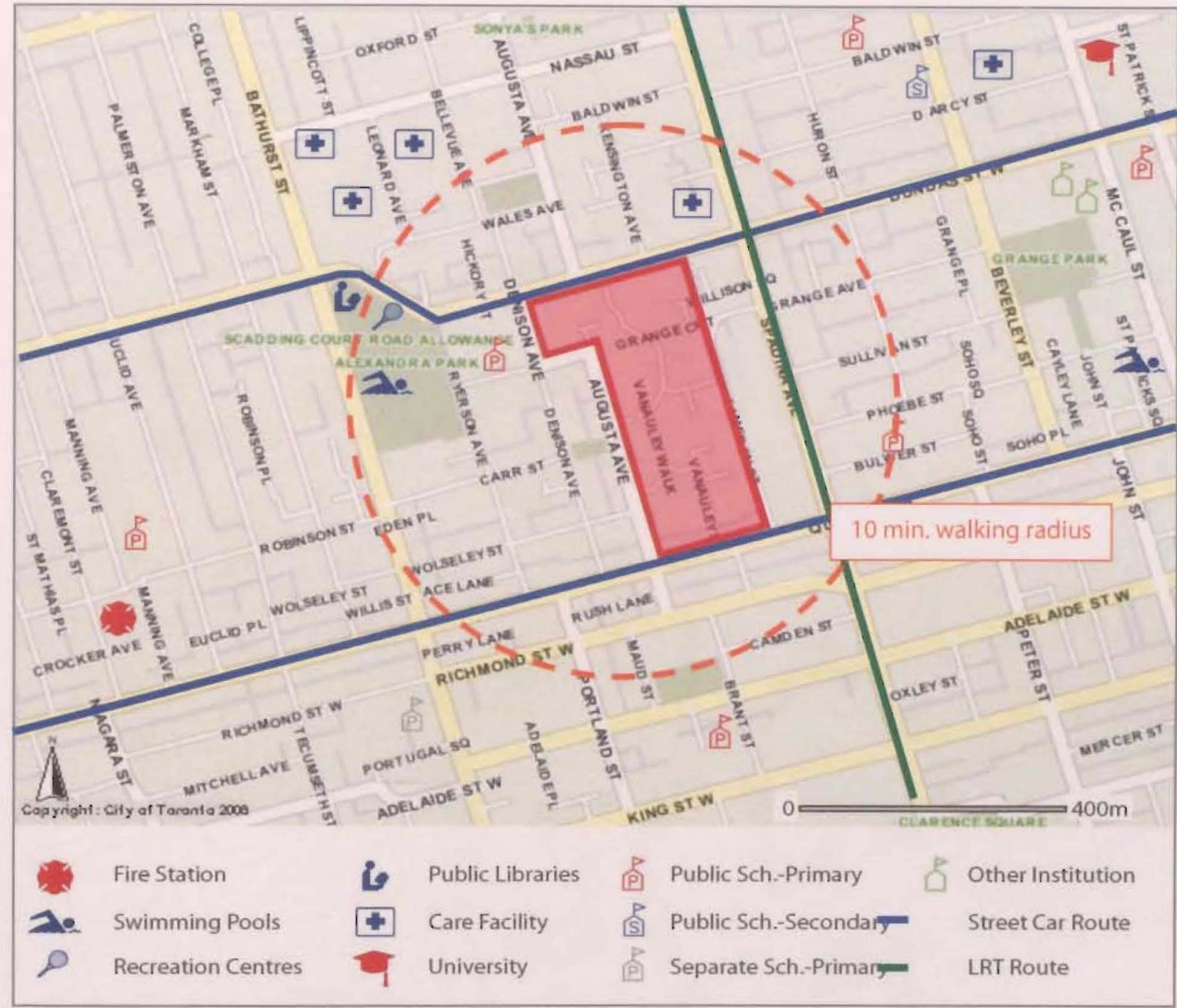

Figure 4.12. Surrounding Facilities. From: http://map.toronto.ca

With Alexandra Park
being centrally located,
residents take
advantage of
surrounding connections
and services such as
public transit,
recreational, community
and health services. This
currently suggests an
asymmetrical level of
connectivity.

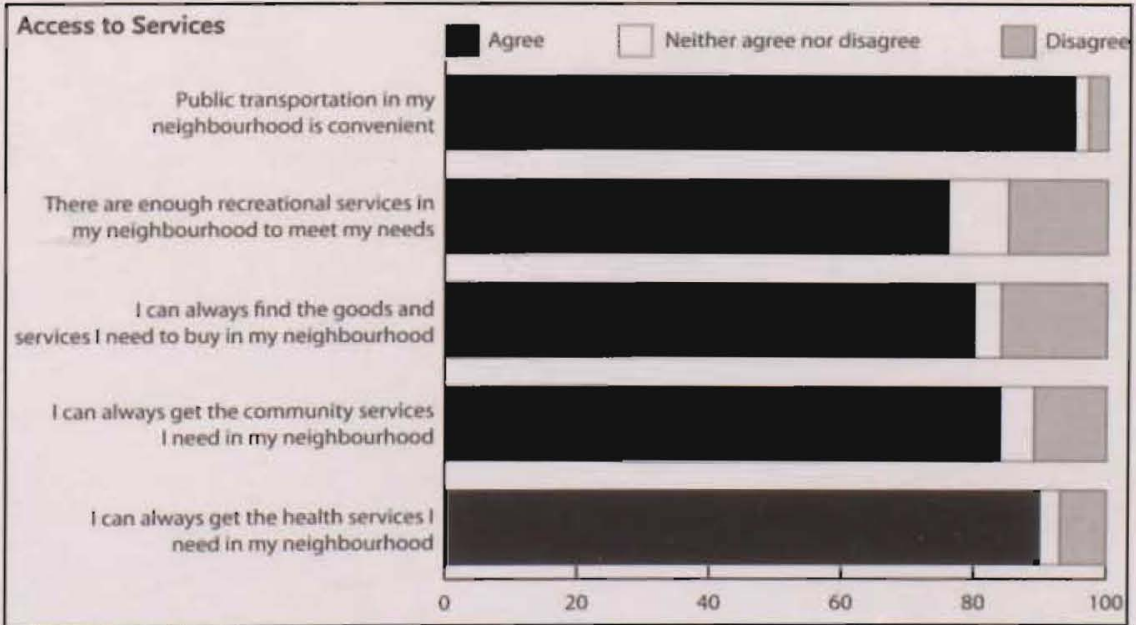

Figure 4.13. Access to Services. From:http://socialplanningtoronto.org 
Existing Site Layout \& Key Map

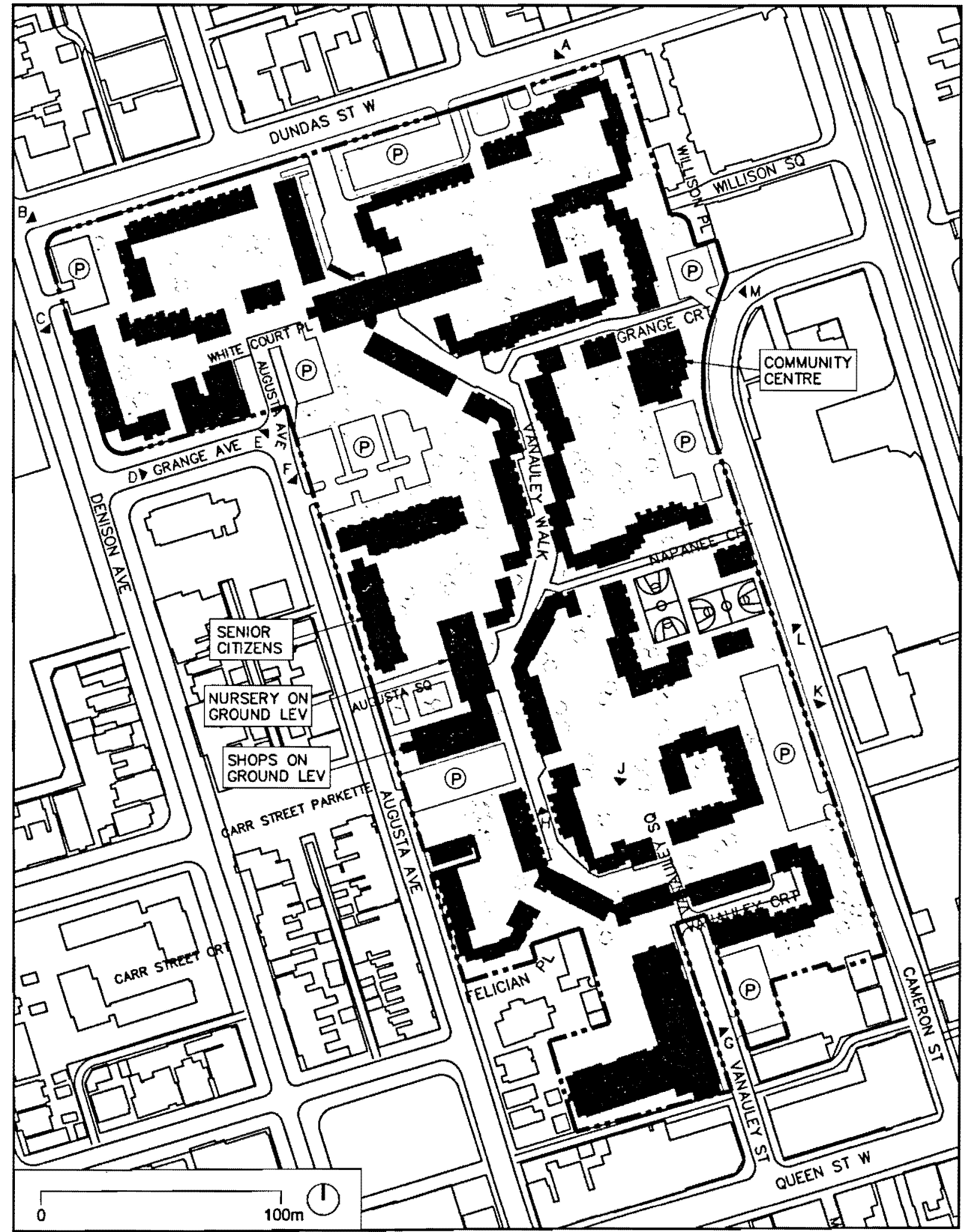

Figure 4.14. Existing Site Layout \& Key Map 


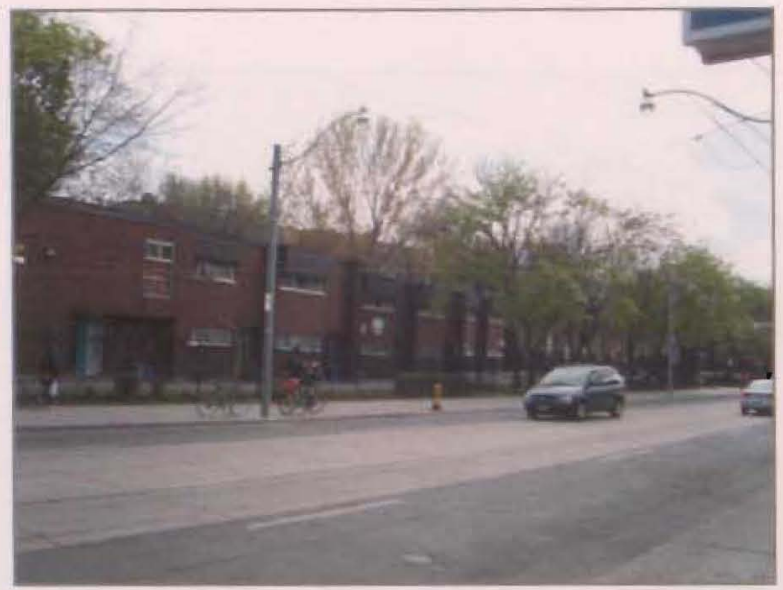

Figure 4.15. Site View 'A'

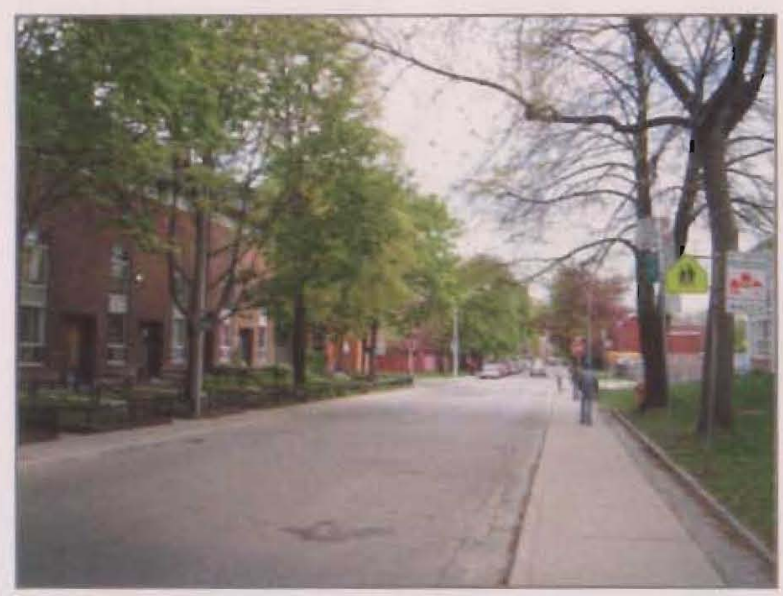

Figure 4.17. Site View 'C'

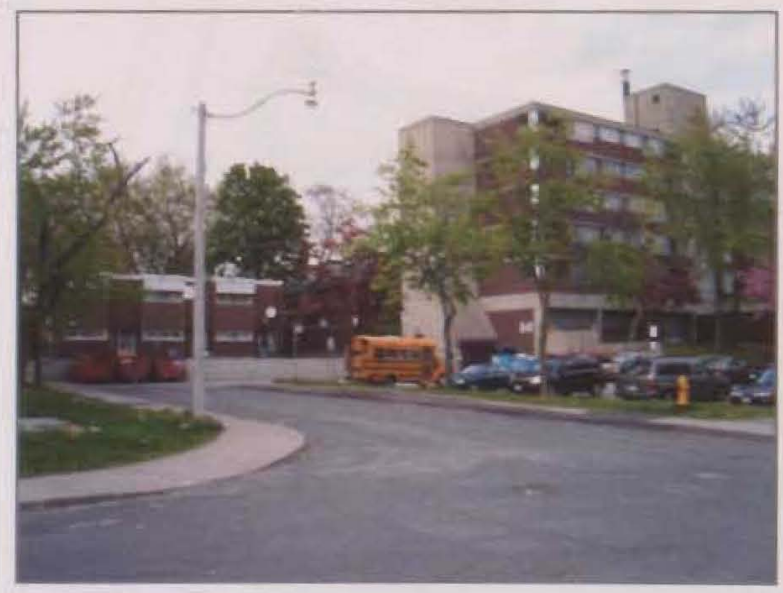

Figure 4.19. Site View 'E'

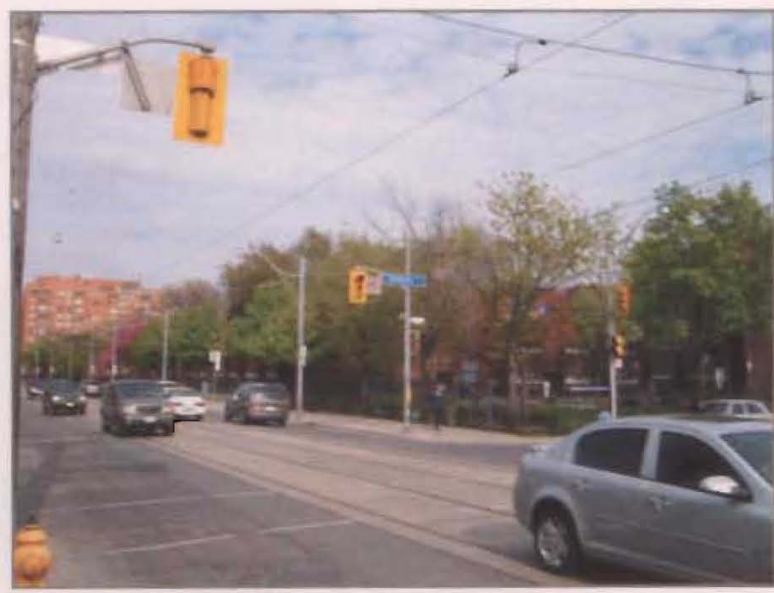

Figure 4.16. Site View 'B'

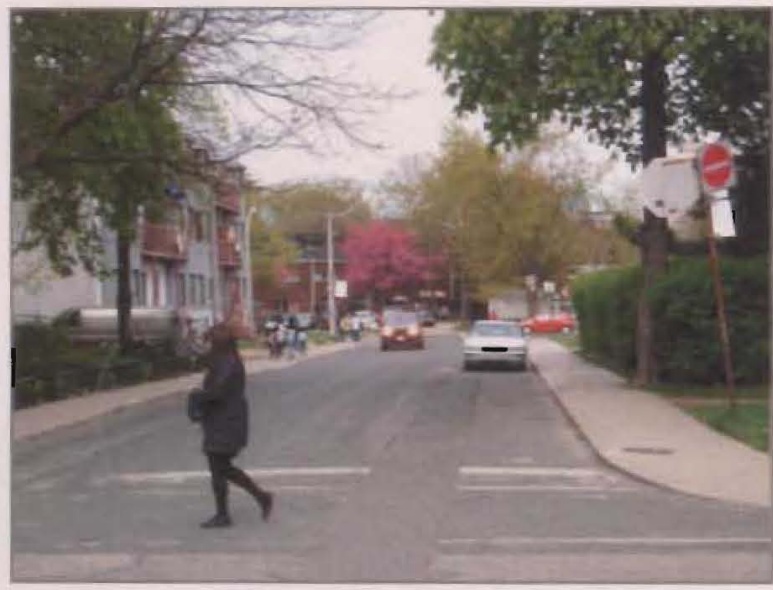

Figure 4.18. Site View 'D'

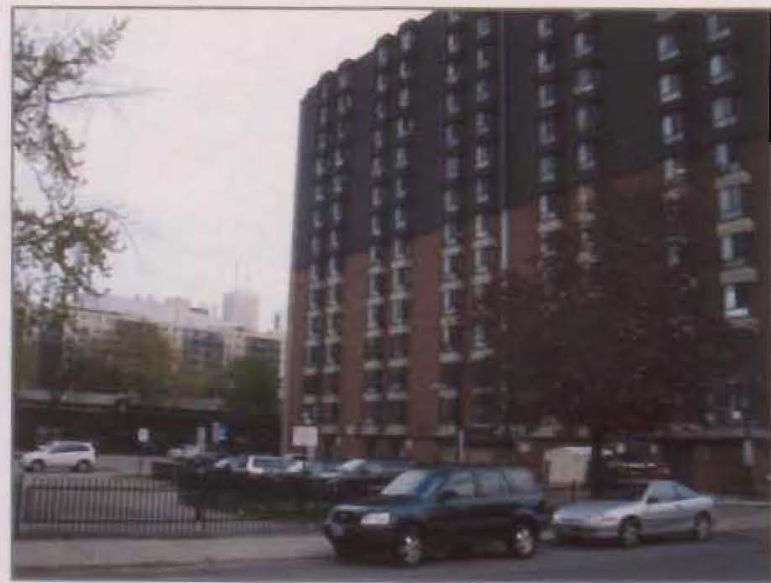

Figure 4.20. Site View ' $F$ ' 


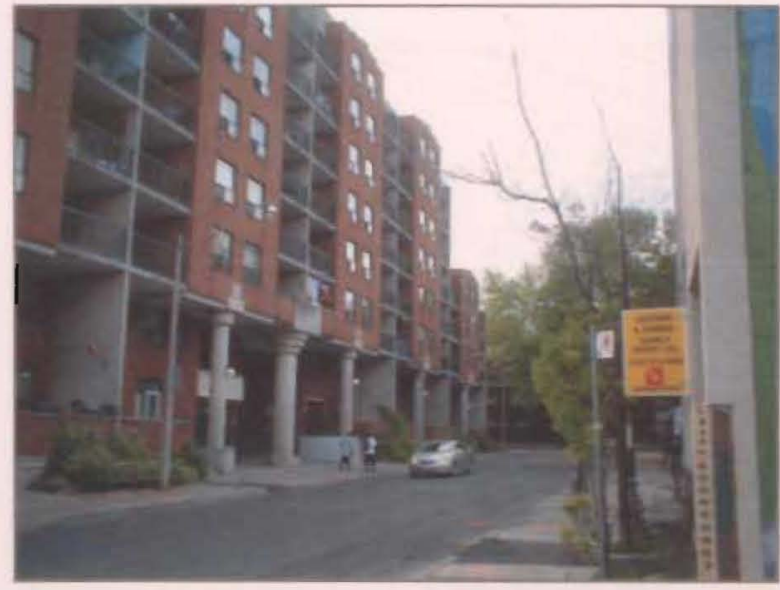

Figure 4.21. Site View ' $G$ '

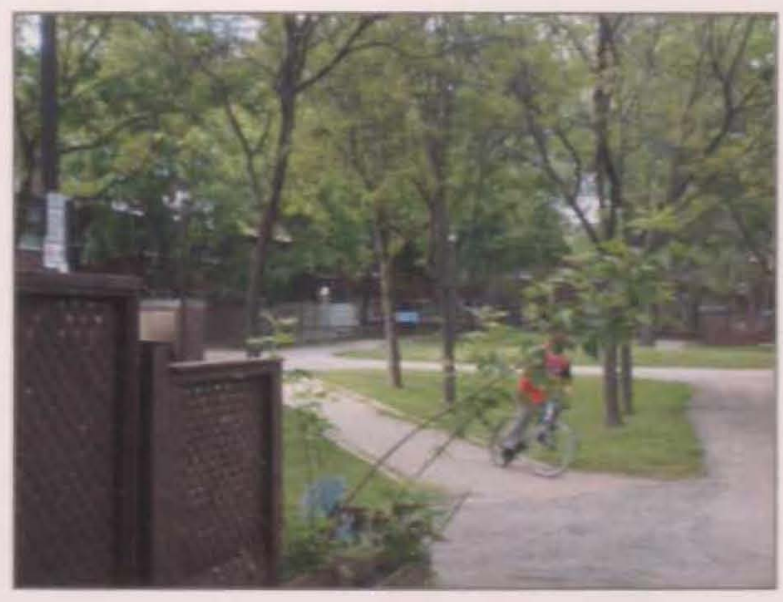

Figure 4.23. Site View 'J'

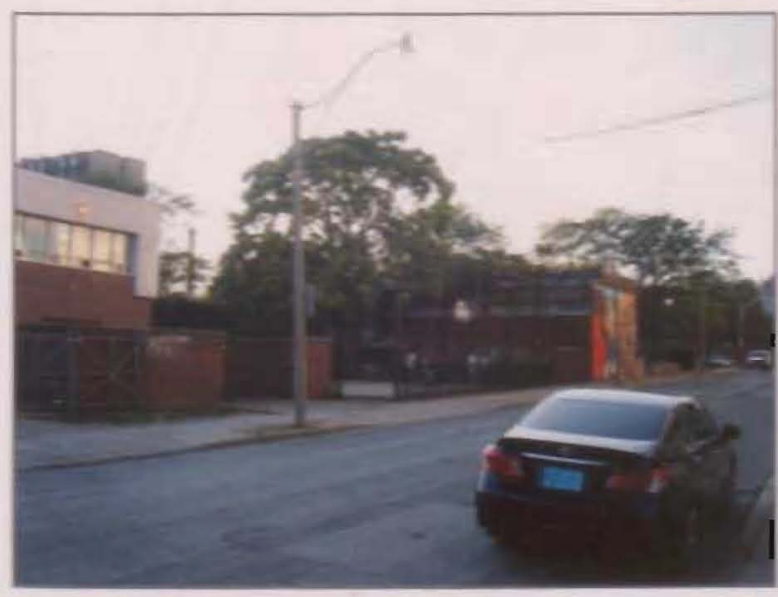

Figure 4.25. Site View ' 2 '

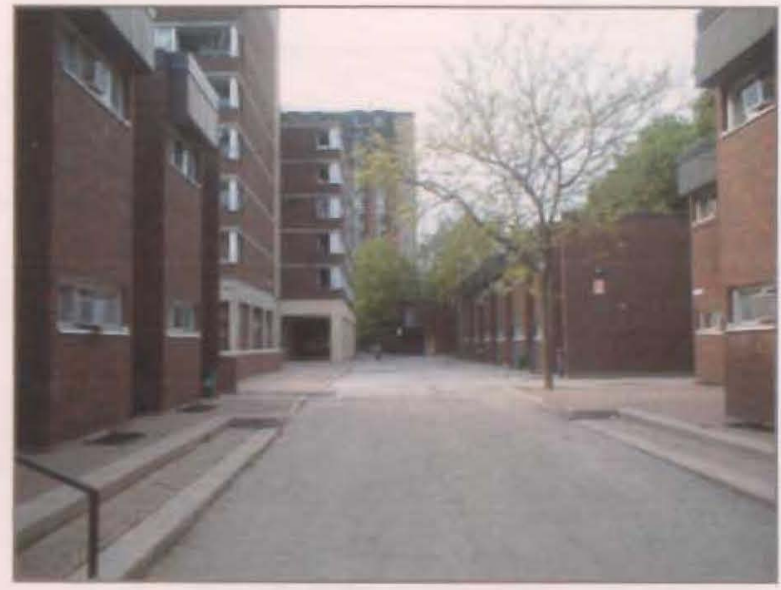

Figure 4.22. Site View ' $H$ '

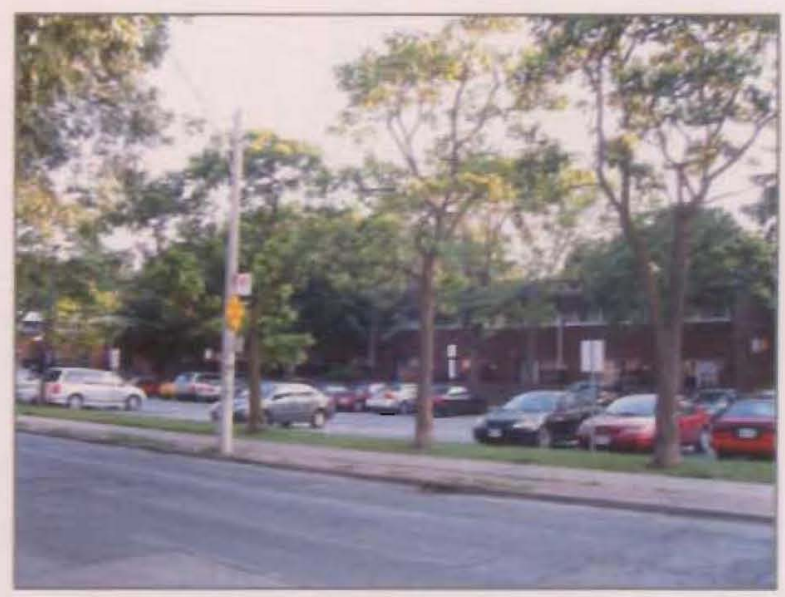

Figure 4.24. Site View ' $\mathrm{K}$ '

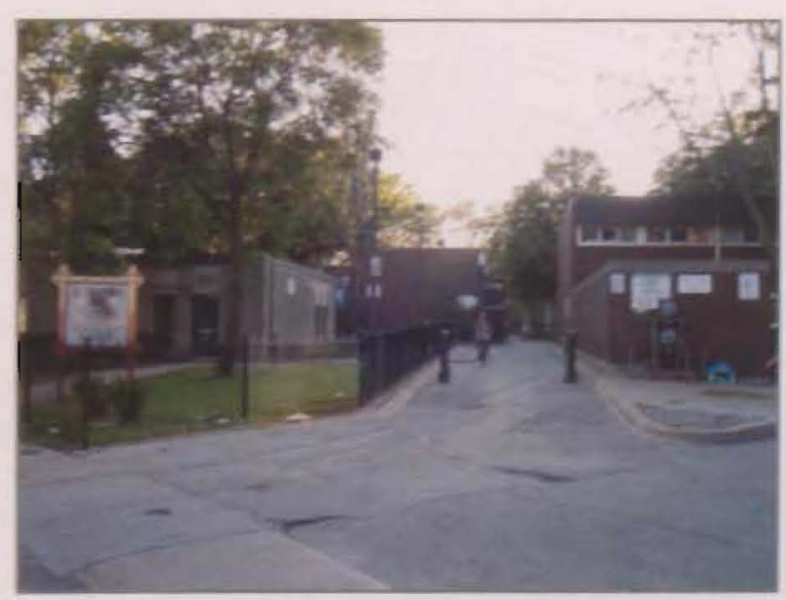

Figure 4.26. Site View ' $M$ ' 
Existing Site Dynamic

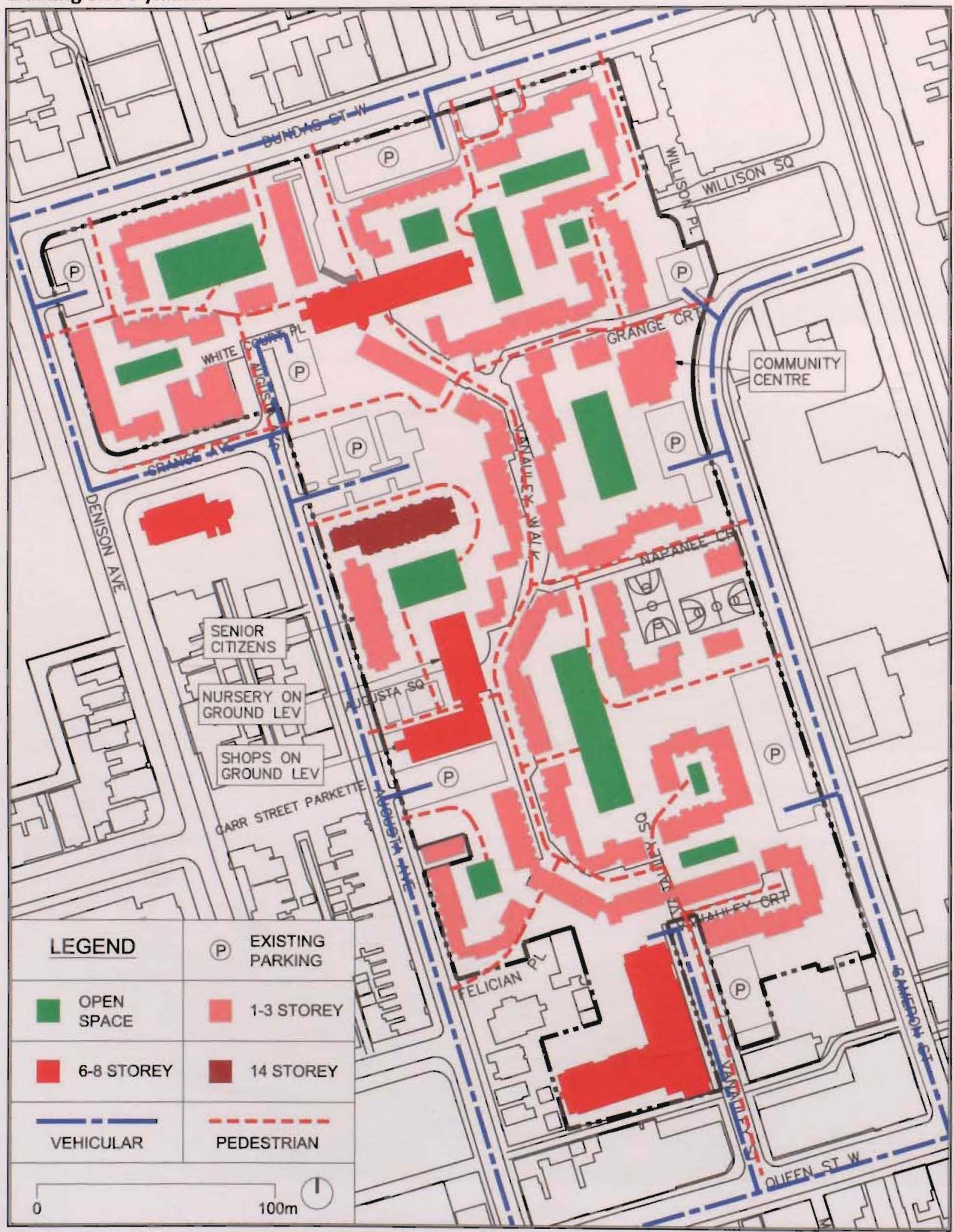

Figure 4.27. Existing Site Dynamic 


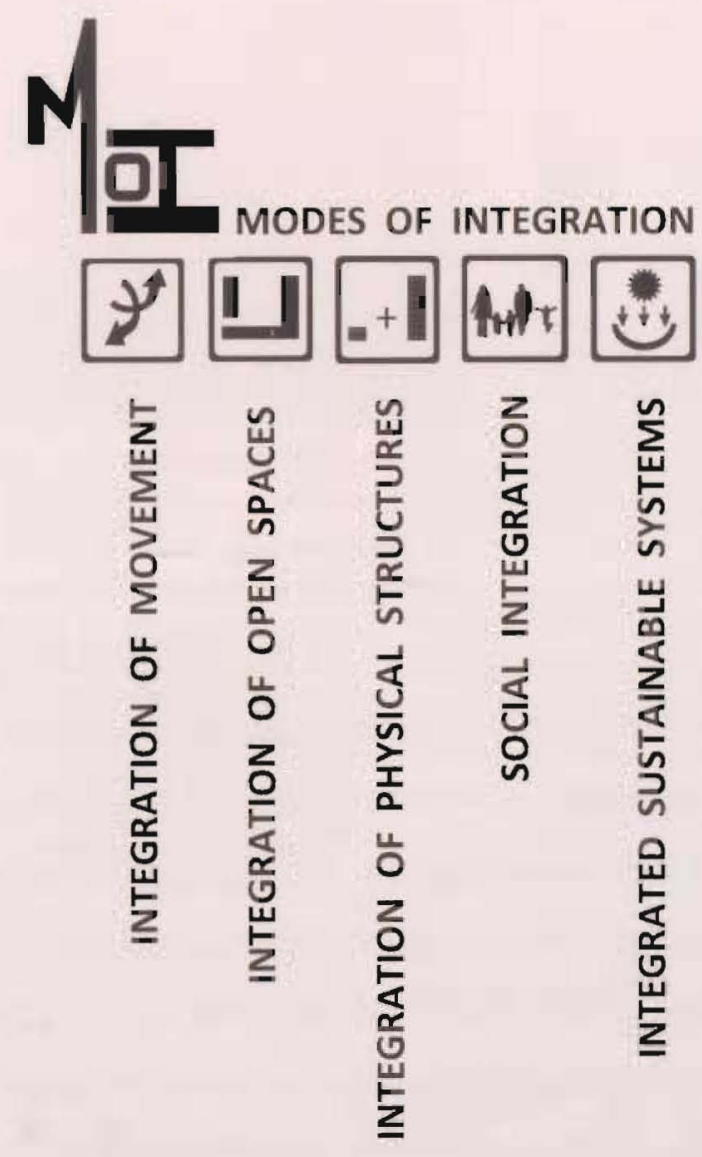



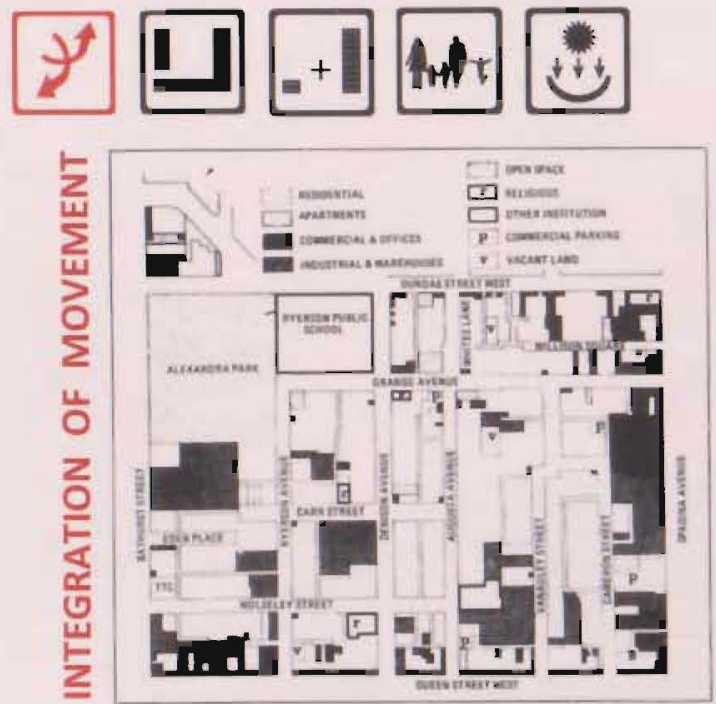

Figure 4.28. Alexandra Park - area before the 1966 redevelopment, highlighting the original Toronto street grid. From:

Menkes W. Z., 1969, Urban renewal:

Alexandra park, Toronto.

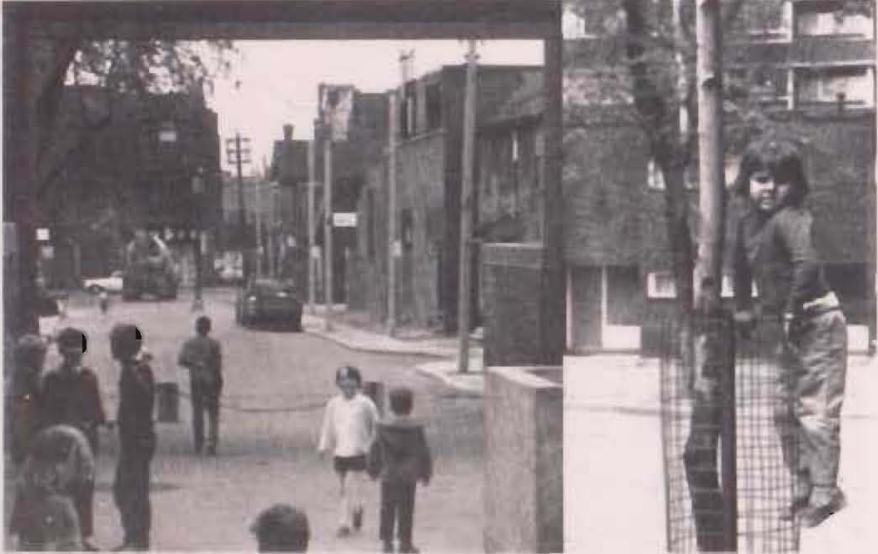

Figure 4.29. Alexandra Park - Augusta Avenue after the 1966 redevelopment, highlighting the separation between pedestrians and vehicles. From: Menkes W. Z., 1969, Urban renewal: Alexandra park, Toronto.

Movement is a term used quite extensively in the field of architecture and can undoubtedly take on various meanings. Whether the meaning be literal or implied, it is typically a positive attribute of a given element of architecture. The 1966 redevelopment of Alexandra Park however, sought to separate the physical (vehicular \& pedestrian) movement of its inhabitants. This was done by closing off existing through roads such as Grange and Augusta Avenues and restricting vehicular movement to the periphery of the site (see figures 4.28 and 4.29 ). The notion at the time was to separate vehicles from pedestrians in attempt to create safer, more user friendly amenity spaces. This was evident in many (now demolished) public housing schemes of the fifties and sixties such as Regent Park (Toronto) and Pruitt-Igoe (St. Louis). Unfortunately, what emerged from this approach was the creation of 'superblocks ${ }^{\prime}$ which were isolated from the broader community as a result. With no vehicular movement nor any level of transparency/ or visibility within the development, crime and drug activity began to dominate their communities. 
Alexandra Park has become a 'super-block', separate from the surrounding urban fabric. Although it has not been overrun by crime and drug activity, there have been complaints and concerns by residents regarding the need for improved security measures. One such measure will be the reintroduction of Grange Avenue as a through road connecting both Denison and Spadina Avenues. 'The Grange' will act as a mixed-use commercial spine, drawing activity from residents and nonresidents alike (see figures 4.30 to 4.35 ).

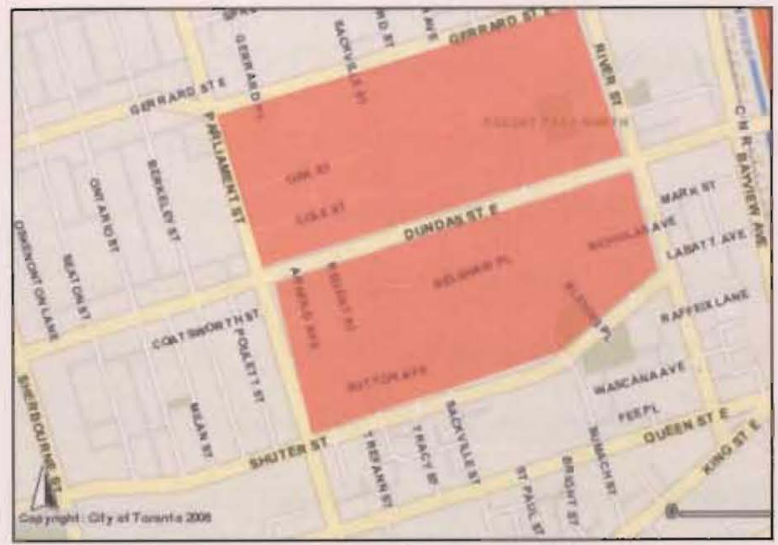

Figure 4.30. Regent Park - 1950 block layout
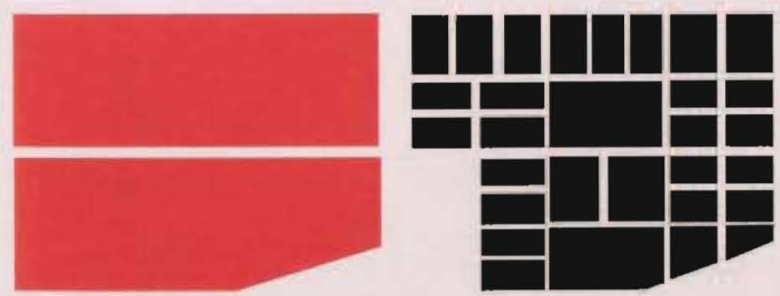

Figure 4.32. Regent Park figure ground: 1950 and present layouts

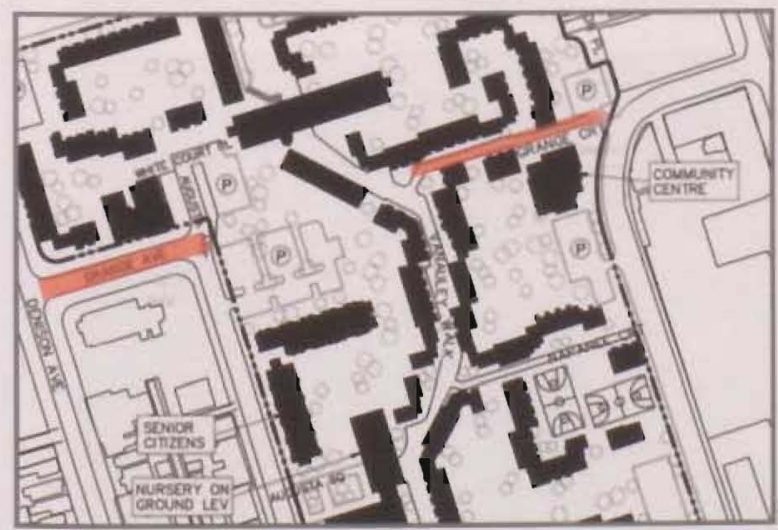

Figure 4.34. Alexandra Park - existing layout along Grange Avenue

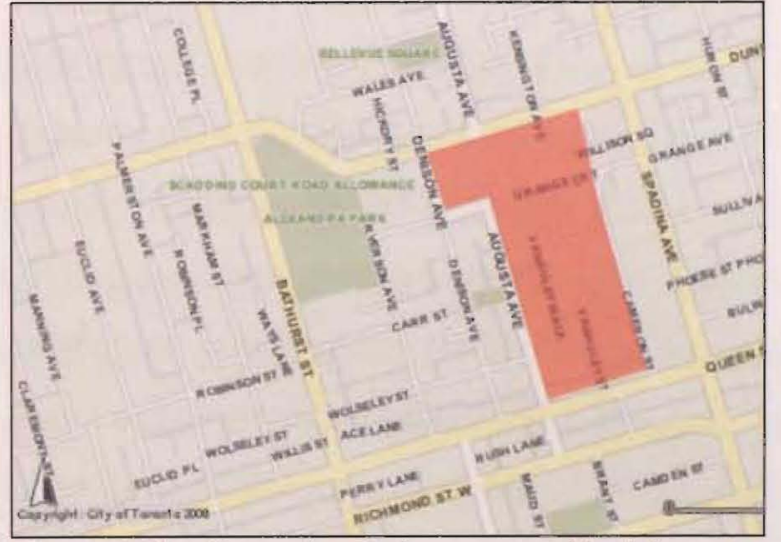

Figure 4.31. Alexandra Park-present biock layout

Grange Avenue has been reintroduced as a through road connecting both Dennison and Spadina Avenue. The Grange acts as a mixed-use activity spine.

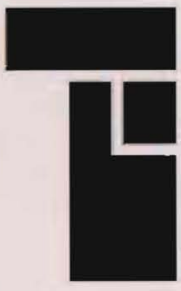

Figure 4.33. Alexandra Park figure ground: present and proposed layouts

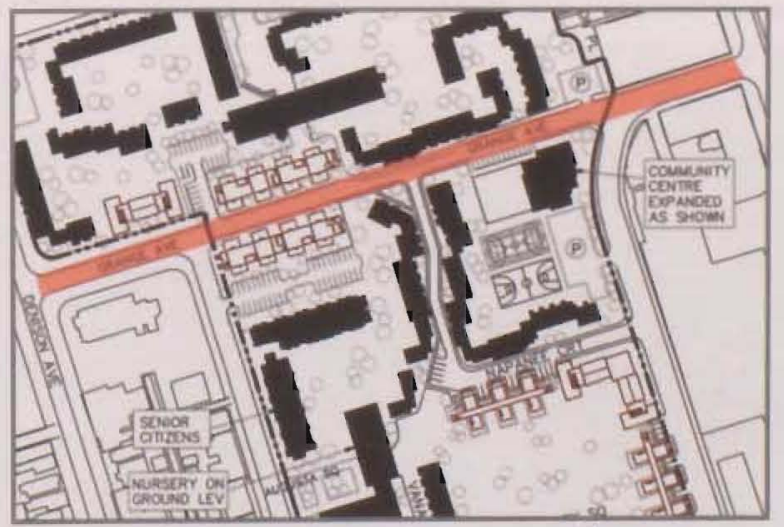

Figure 4.35. Alexandra Park - proposed layout along Grange Avenue 


\section{MODES OF INTEGRATION}

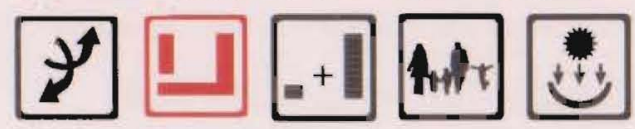

i Currently, there are a series of relatively small, open spaces scattered around \& Alexandra Park. An investigation of the site and its surrounding areas however, जे indicated that these spaces were underutilized by residents and that children opted to play on interior streets (Vanauley Walk, etc.) as opposed to these green 능 spaces that were either too small to play football, or had too many obstacles $z$ (trees, planters, etc.) standing in the way of bike rides. The existing layout also made it impossible to establish a place of gathering (see figures 4.36 to 4.39 ). The design response was to create a central activity core that could support these $\geqq$ various uses as well as establish a link between neighbouring communities.

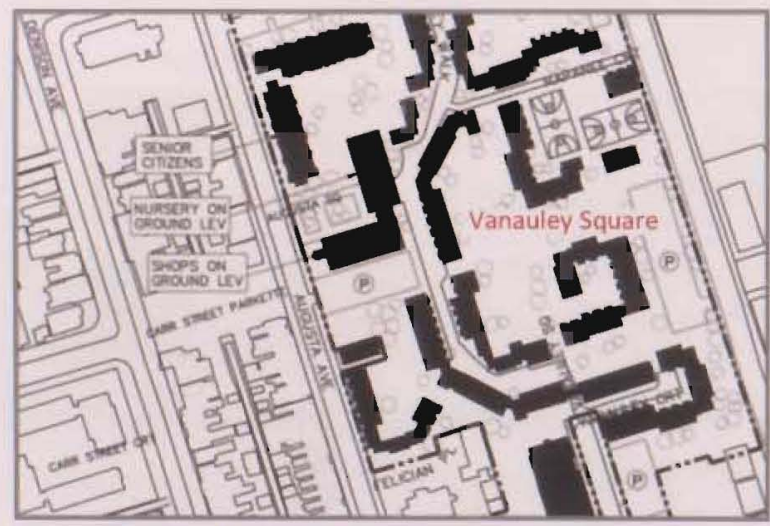

Figure 4.36. Alexandra Park - existing layout

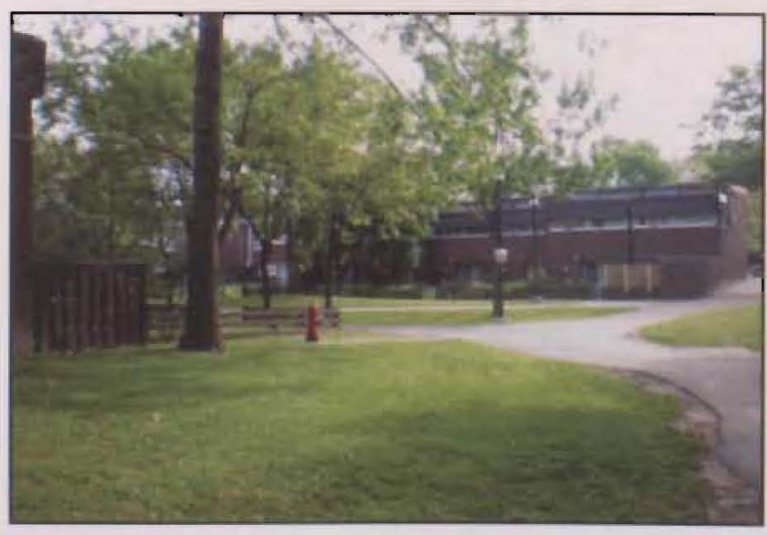

Figure 4.38. Vanauley Square - existing condition

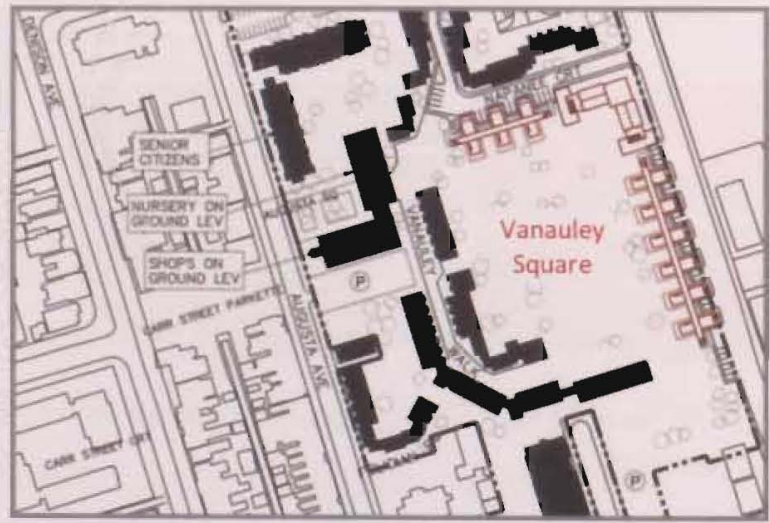

Figure 4.37. Alexandra Park - proposed layout

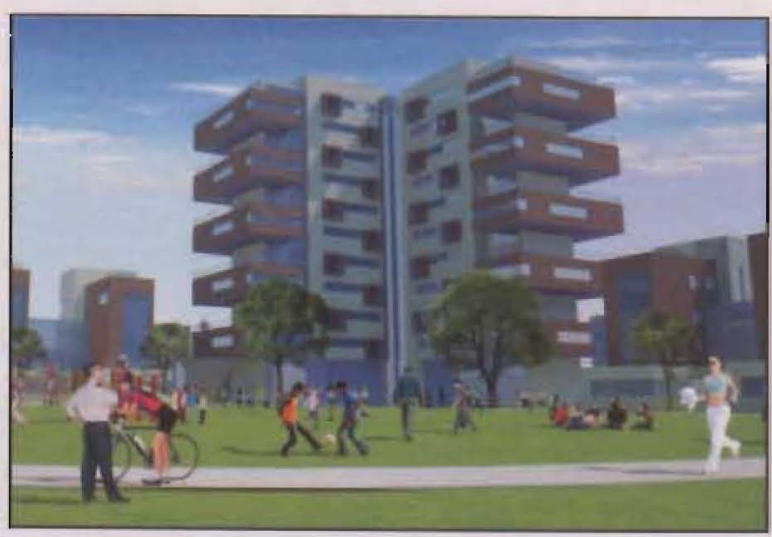

Figure 4.39. Vanauley Square - proposed condition

Past - Present - Future: The Revitalization of Social Housing in Canada 


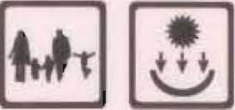

w Typically, when we consider integration in an architectural context, we think

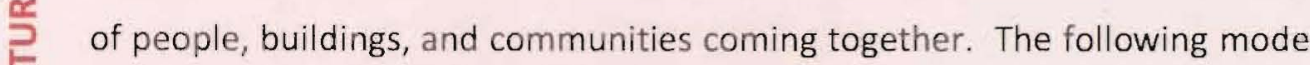
$\underset{2}{2}$ of integration however, seeks to take the idea of 'building fusion' to a more $\checkmark$ literal point of analysis. The integration of varying building typologies as a $\vec{\delta}$ means of creating a 'design type' that extracts the positive elements of each building. A fusion between a high rise (or mid rise) building and a townhouse for instance. The privacy and sense of ownership of the townhouse without the typical low density issues. These combinations, if brought together in a sensitive manner could lead to the emergence of a rational compromise between the two extremes. Figures 4.40 to 4.45 below outline the existing typologies as well as the proposed integrated systems.

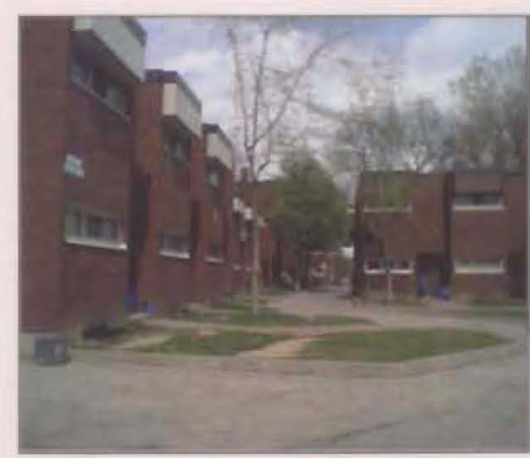

Figure 4.40. Existing Townhouse

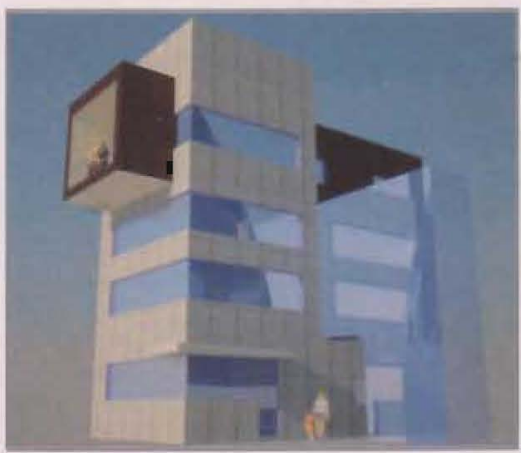

+ Fig. 4.43. Townhouse+Midrise

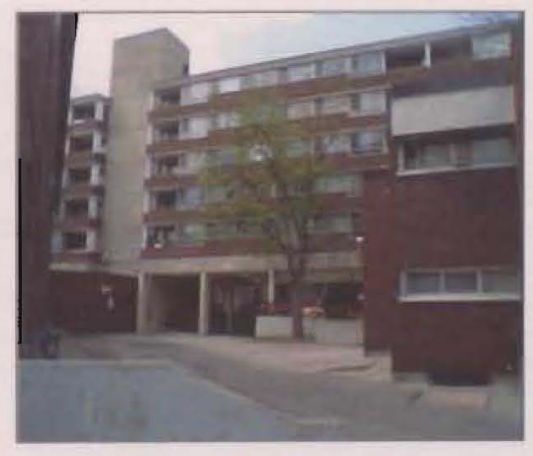

Figure 4.41. Existing Midrise

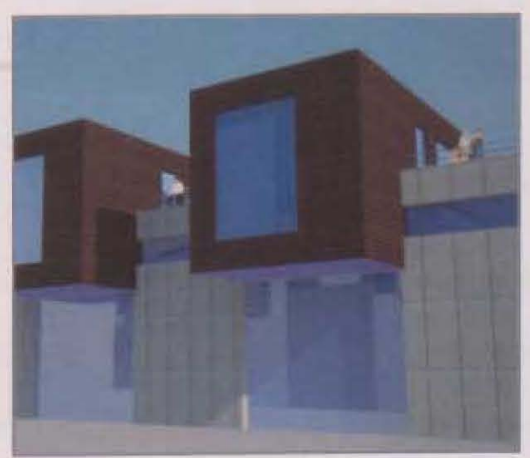

Fig. 4.44. Commercial+Midrise $+{ }^{+}$Fig. 4.45. Townhouse+Highrise

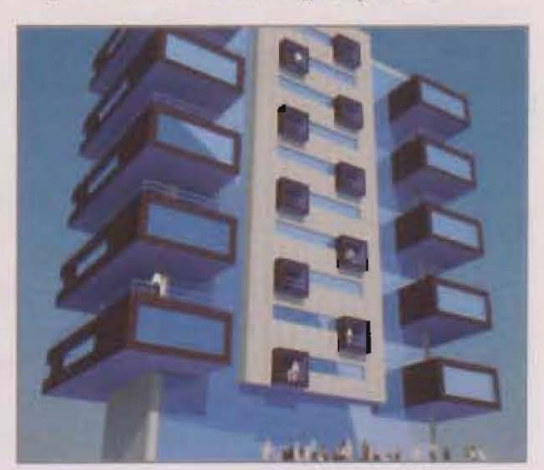

Figure 4.42. Existing Highrise

Past - Present - Future: The Revitalization of Social Housing in Canada 
MODES OF INTEGRATION
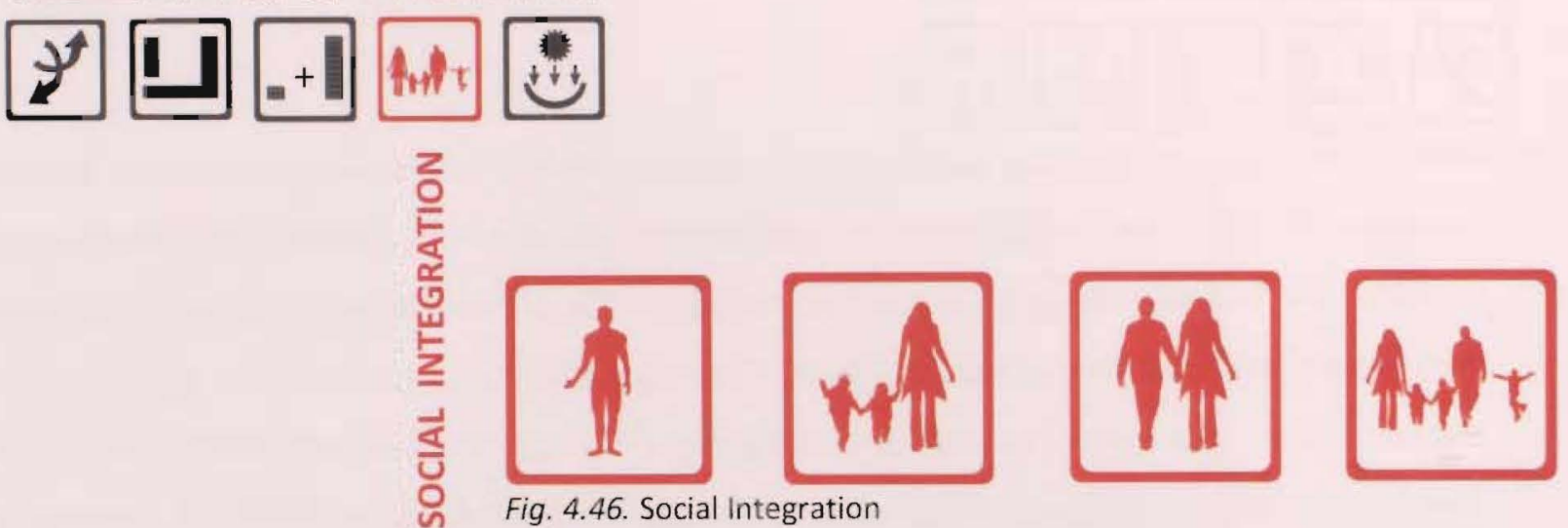

Due to past failures, current projects have rejected the idea of creating low-income neighbourhoods that consist solely of R-G-I housing. For instance, the Toronto Community Housing Corporation (TCHC) now has a mandate whereby its housing developments are composed of $60 \%$ market rental and $40 \%$ rent-geared-to-income units.

Alexandra Park currently has a social composition of $100 \%$ R-G-I. Although this has not led to the unfortunate fate of its counterparts (due to factors such as its central location, diverse cultural make-up, and it's relatively small scale when compared with others), a mixture of economic statures can only improve the social integration of the area. Mixed-income communities often carry a diverse range of activities within a development. They also provide an environment with positive role models where residents may gain inspiration and identify with progressive alternative benchmarks for success. One contrary to what may otherwise be a drug-related path.

The design response to this was to introduce market rental units (with opportunities for ownership) to the revitalization plan and encourage the mixing of various family dynamics (singles, couples, single parent and two parent households) by virtue of the design of spaces (see figure 4.46). This was achieved by creating clusters of residentia! units with varying living capacities; one, two, three, and four bedroom units. Where possible, family units were located at grade, thereby creating a direct transition (for children) into amenity areas and playgrounds while single and couples' units were elevated with balconies and gardens. Private retreats within a public urban environment. See the 'Design Response' section of this chapter for the architectural design proposals. 
MODES OF INTEGRATION
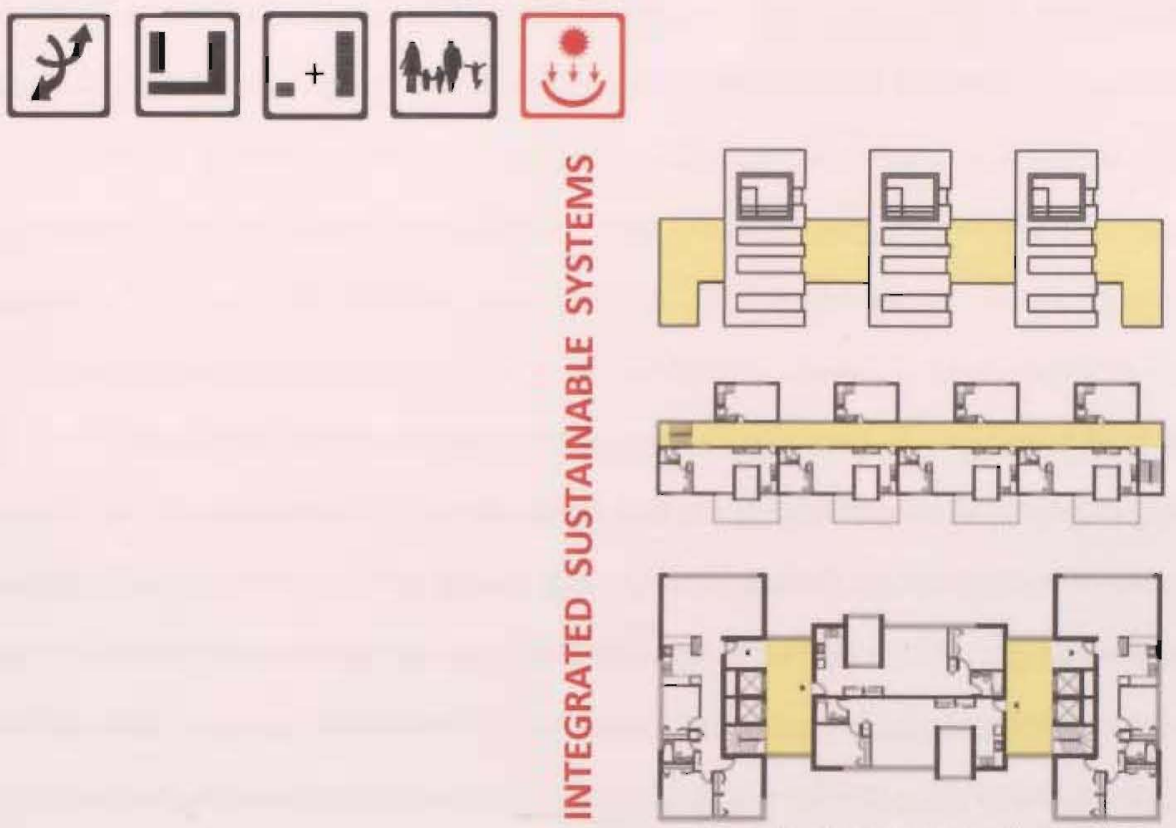

Fig. 4.47. Day lighting of corridors

No new architecture should proceed without proper consideration of the environment and sustainability. Integrated neighbourhoods are no different. In fact, even greater attention should go to these developments where issues of maintenance and operating costs are of critical importance. These costs should be kept to a minimum in order to ensure reasonable rental rates for tenants. Initiatives such as energy production and efficiency, water collection and re-use are just a few methods to achieve this.

The physical design proposals for Alexandra Park incorporate sustainable systems such as energy generation and water collection. The circulatory systems for all building typologies, for example, are heavily glazed to generate electricity through photovoltaic coating. This also has the effect of maximizing daylight within these spaces as a bi-product of its materiality (see figure 4.47). 


\section{INTEGR4 \\ Design Response}

As introduced by the 'modes of integration' that were used as a guiding tool for design implementation, the following pages propose a concept for the revitalization of Alexandra Park. The previously discussed integrated elements of movement, open space, sustainability, and social \& physical integration are embodied in this design. These elements have been carefully considered to inform the design response and have played a critical role not only in generating the building form but also the social and physical composition of the proposal. Figures 4.48 and 4.49 offer a side by side comparison of the existing and proposed site plan, giving a general overview of the key areas of intervention in relation to the broader context. A series of vignettes follow (figures 4.51 to 4.56 ) to present some of the critical (exiting and proposed) alterations that were considered.

This revitalization proposes the removal of 50 dwelling units, some of which are nearing a derelict state and others which offered an alternative to space planning methods at the time. Material from existing buildings being removed will be reused in various ways for new construction, for example; scrap brick/block ground into aggregate, gypsum used as a soil amendment, wood waste ground into mulch, etc. This building removal approach makes way for the creation of more generous and accessible open/public spaces, the insertion of a vibrant commercial identity, and the introduction of 150 new residential units that embody physical and social integration. Each housing design typology seeks to create a seamless fusion between building (physical structure), social awareness (family dynamic), and sustainability (approaches in the methods of construction as well as long-term benefits in operating cost savings). 
It is becoming increasingly difficult to break free from mid rise and high rise implementations when designing or redesigning livable communities within an urban context. Nonetheless, it is desirable for occupants to dwell in a place of relative privacy and adequate levels of security, a place that promotes a sense of ownership, whether actual or perceived. Perceived ownership relates to the idea that, although an occupant may not actually own their dwelling/residence, a sense of ownership is brought about by the nature of the space (evident separations, private balconies, gardens, etc.) as well as a greater level of tenant engagement that enables/encourages the occupant to play an active role in suggesting and carrying out improvements to their space and to their broader community. These are some of the characteristics that typify a townhouse. As such, I see merit in creating a fusion between the $\mathrm{mid} / \mathrm{high}$ rise building typology and the townhouse. Not only would it emphasize privacy and ownership in a relatively dense manner/environment, it would also take advantage of the energy saving measures inherent in townhouse design. An example of which is the extensive use of natural day lighting as most, if not all exterior walls are exposed to the elements. Far too many mid and high rise buildings are designed with single or double loaded corridors which never see the light of day. The following designs are sensitive to this and other 'green' issues as evidenced by the arrangement of building form as it relates to its circulatory system and energy reduction. 


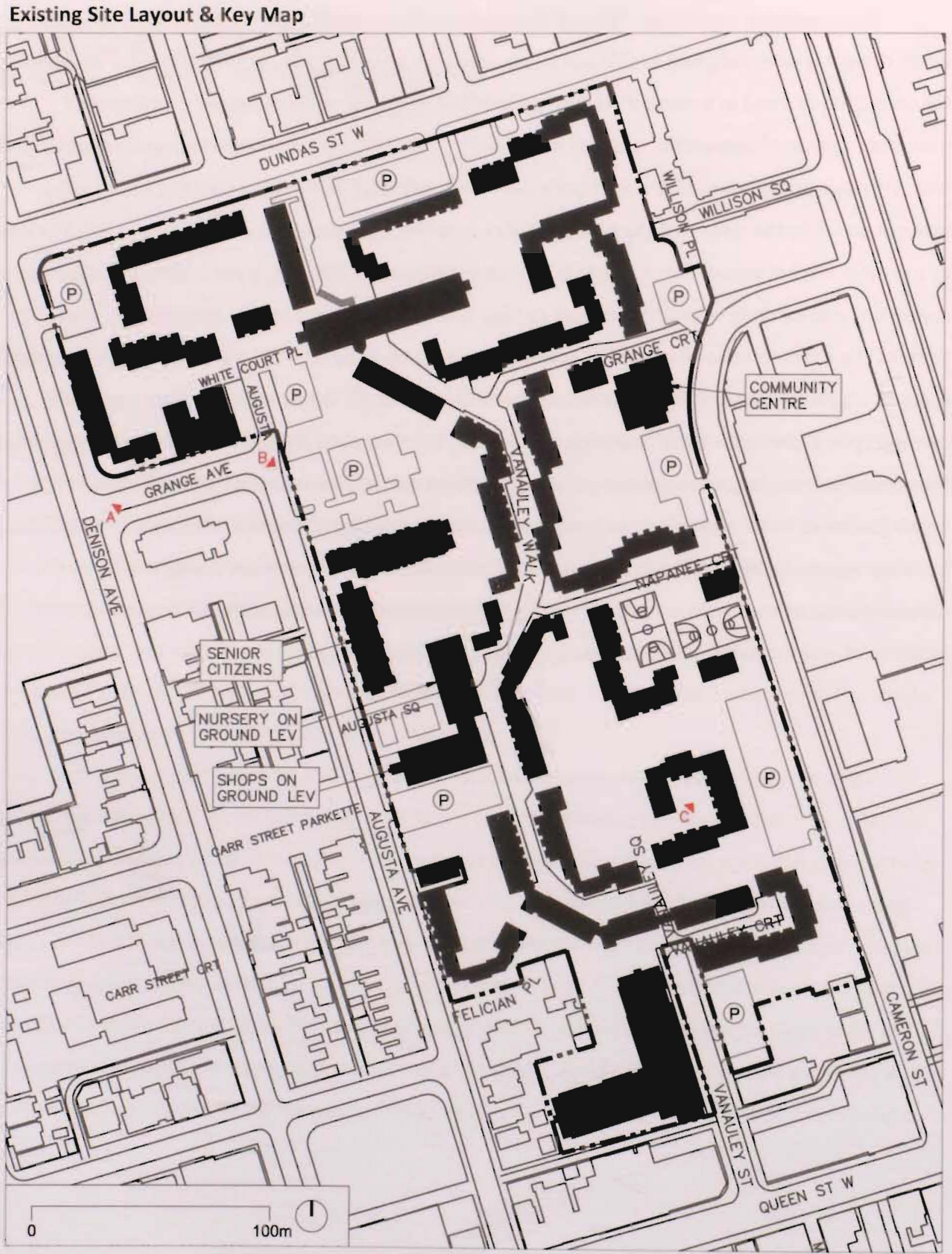

Figure 4.48. Existing Site Layout \& Key Map 
Proposed Site Layout \& Key Map

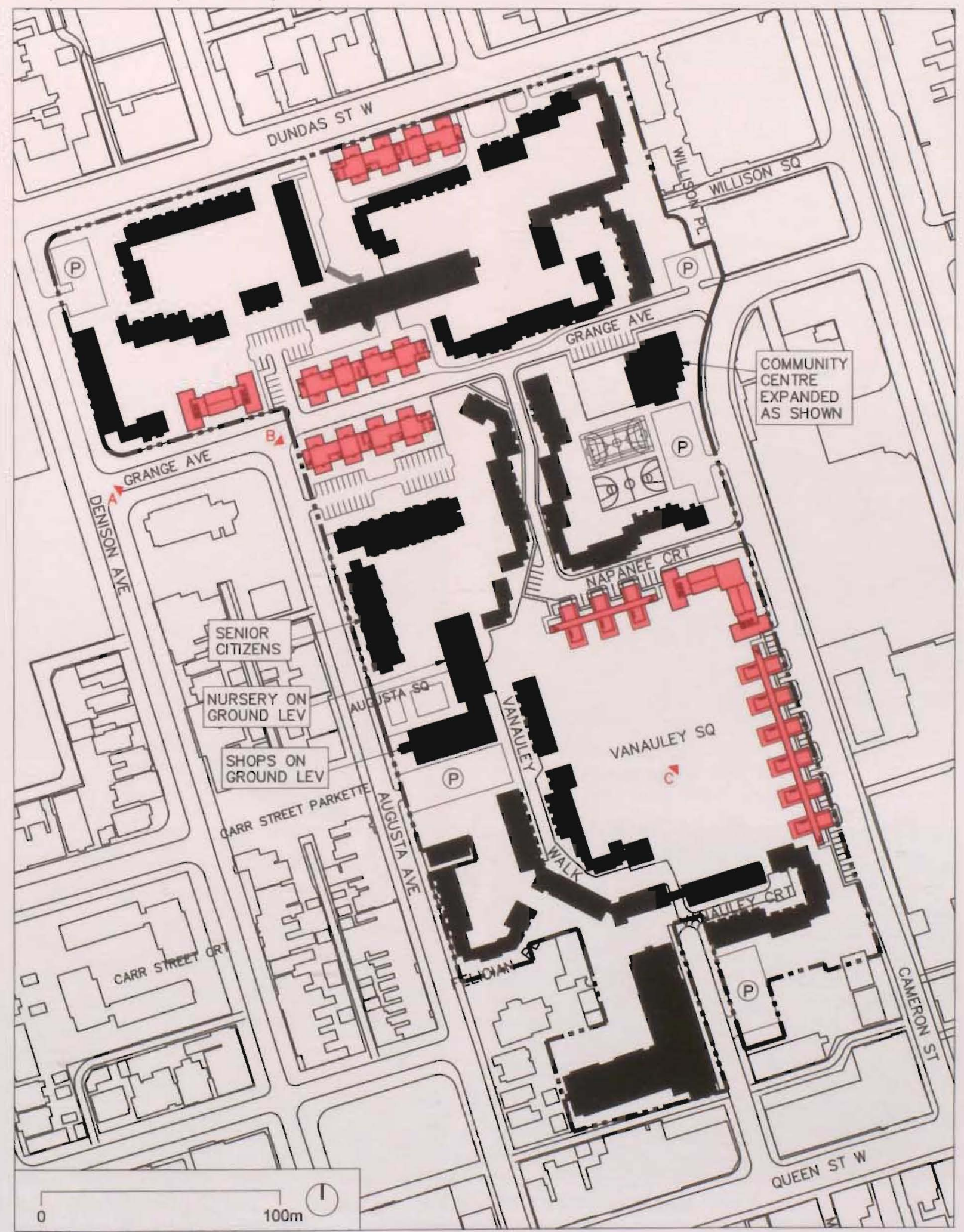

Figure 4.49. Proposed Site Layout \& Key Map 
Proposed Site Dynamic

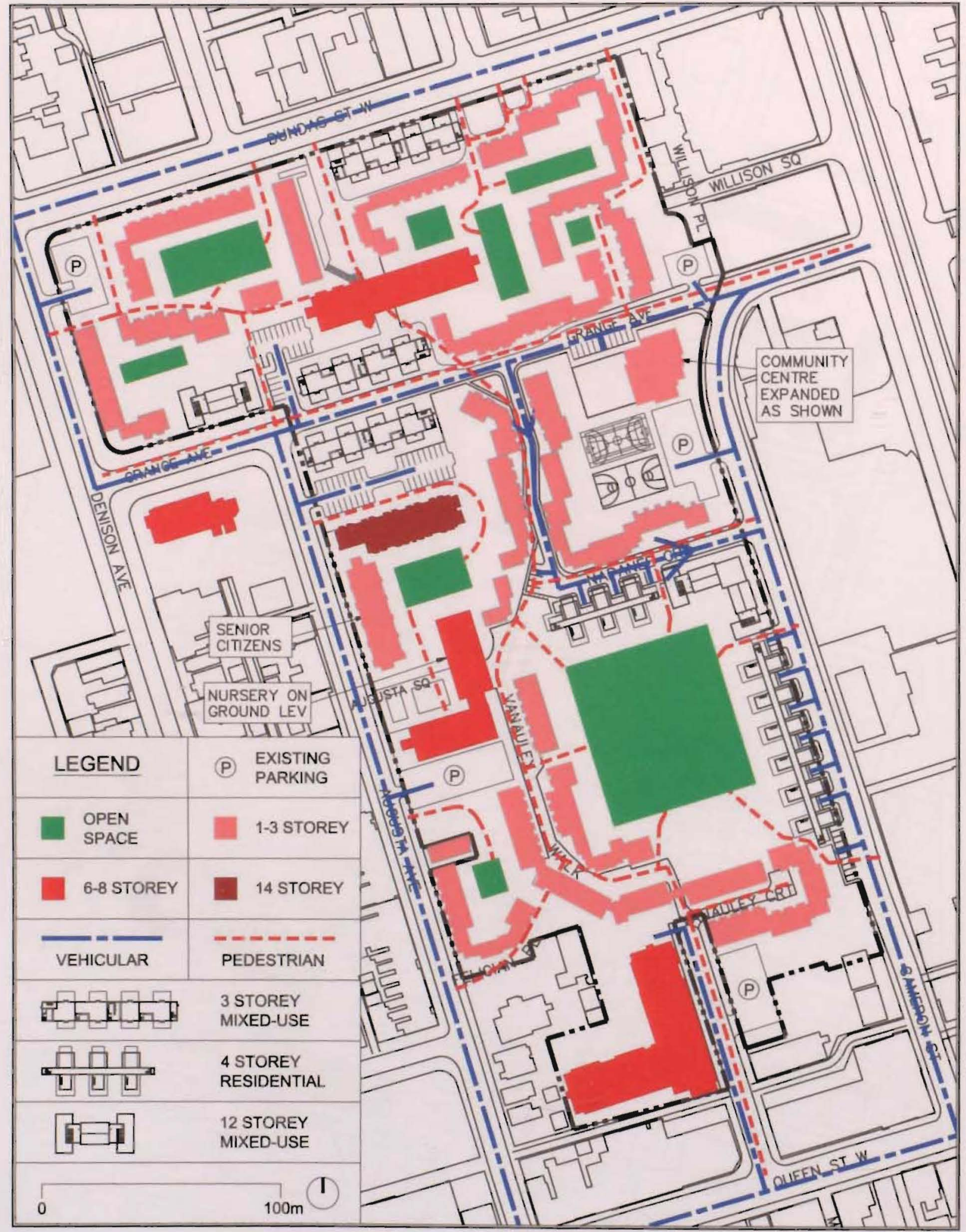

Figure 4.50. Proposed Site Dynamic 


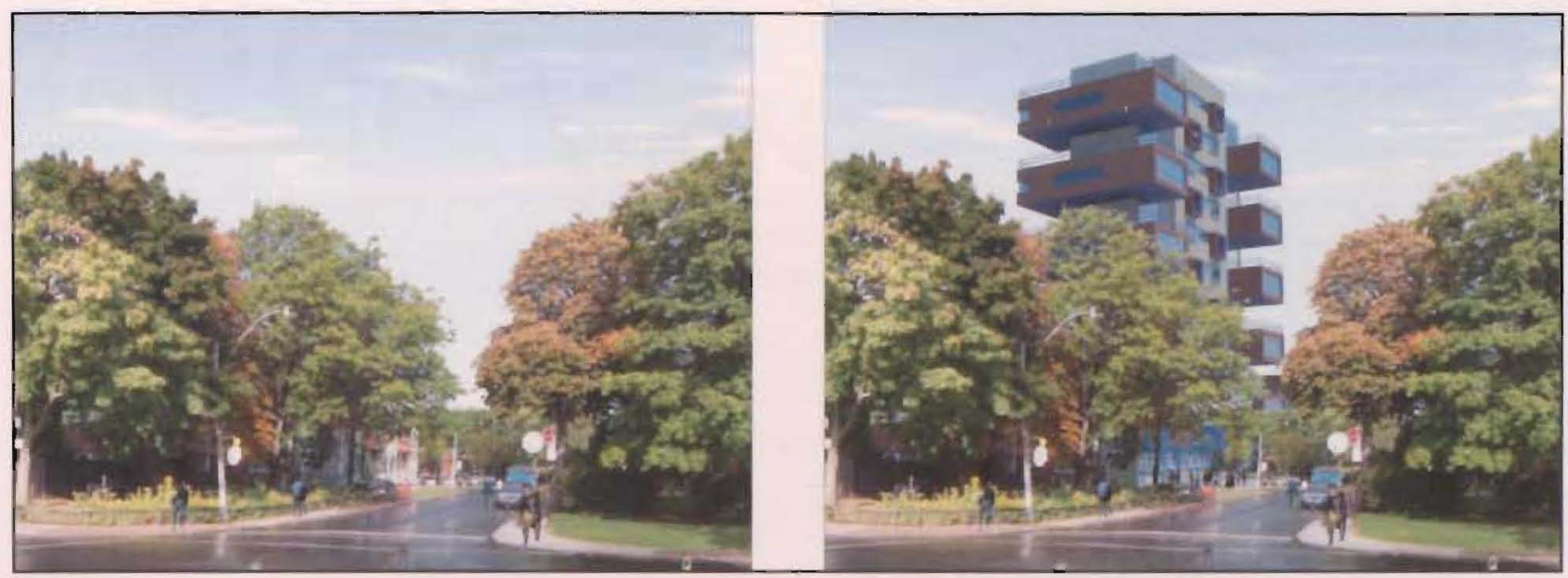

Fig. 4.51. Existing Site View ' $A$ '

Fig. 4.52. Proposed Site View 'A'

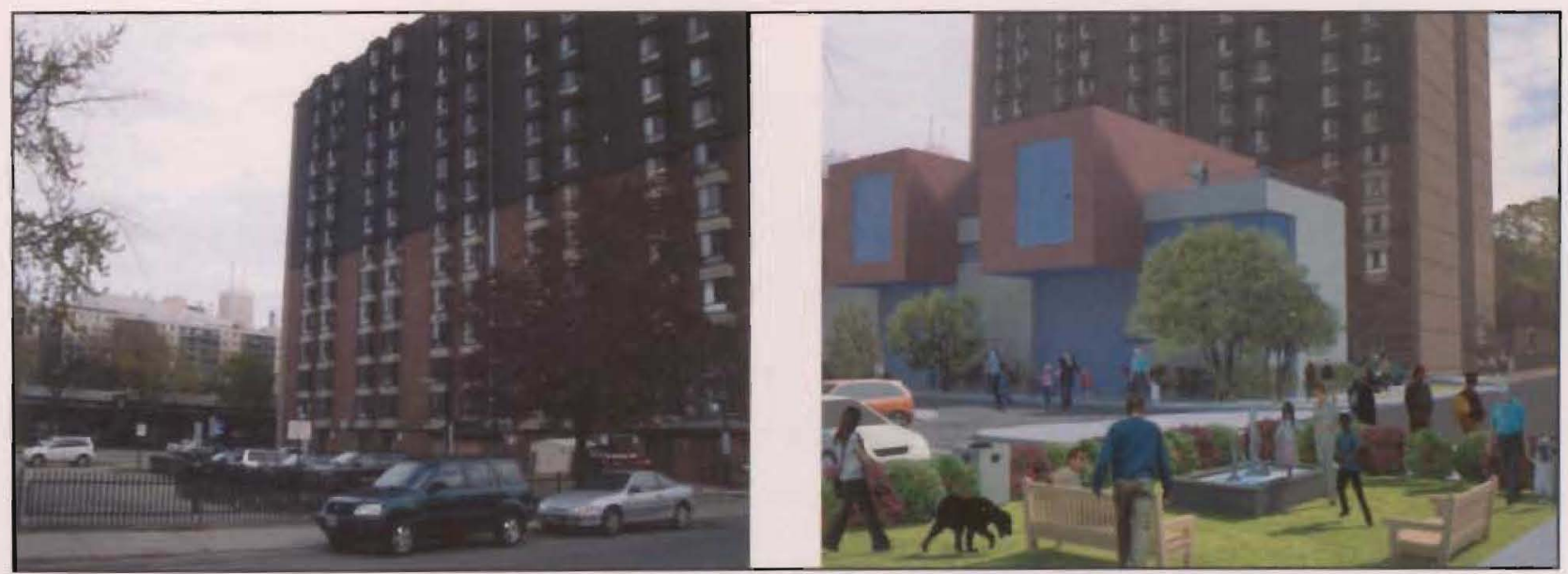

Fig. 4.53. Existing Site View 'B'

Fig. 4.54. Proposed Site View 'B'

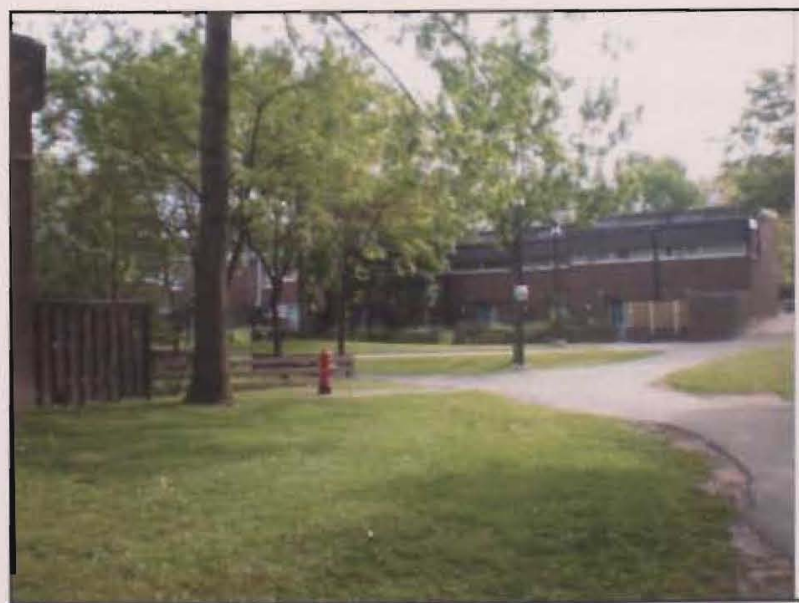

Fig. 4.55. Existing Site View ' $C$ '

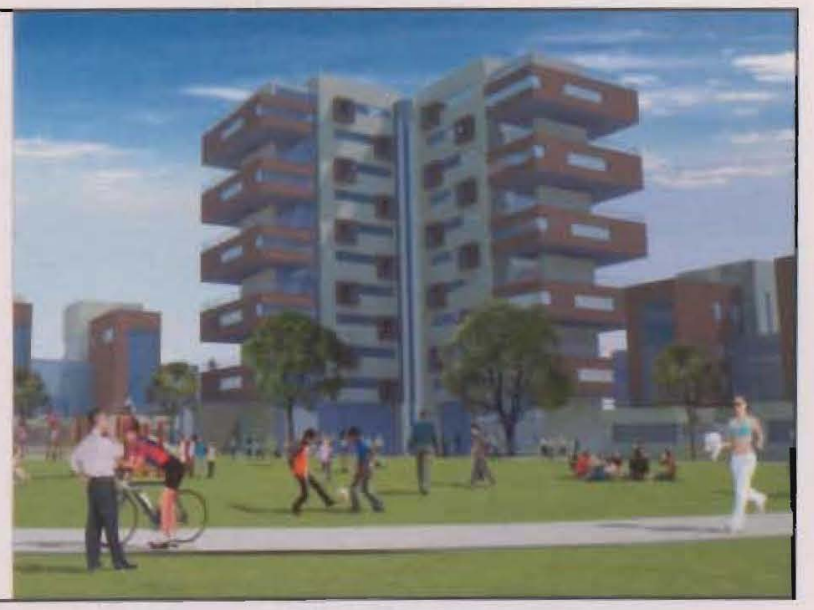

Fig. 4.56. Proposed Site View 'C'

Past-Present - Future: The Revitalization of Social Housing in Canada 


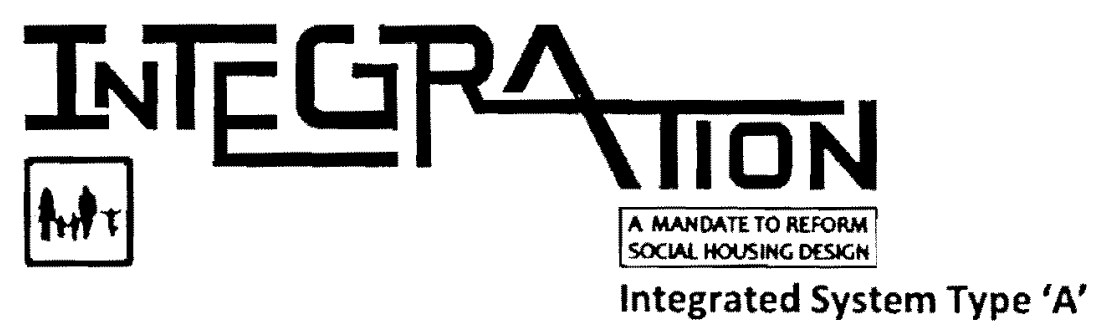

In theory, the Integrated System Type ' $A$ ' concept is a hybrid design, composed of a mid rise housing typology and a single occupancy townhouse. As mentioned earlier, this design approach takes advantage of the density requirements of a mid rise (within an urban context) while incorporating the elements of privacy and sustainability that are typical to the townhouse design.

The design is essentially a fusion between two single occupancy units ( 1 \& 2 bedroom units), two family occupancy units ( $3 \& 4$ bedroom units), and a central, circulatory system which connects the two (see figures 4.57 to 4.60 ). This building fusion is arrayed along the spine of the circulatory system with a spacing of $6 \mathrm{~m}$ to accommodate two parking spaces at the front and a private yard/allotment garden in the rear (see figures 4.61 and 4.62 ). The circulatory system is a fully glazed, double-loaded corridor that not only generates electricity through its photovoltaic coating, but it also draws daylight into the corridors as a result of its design and materiality.

This Integrated System Type ' $A$ ' has been introduced to Alexandra Park along Cameron Street (where a large parking lot once existed) and Napanee Crescent (where the once utility easement has been widened to support single lane traffic) (see figure 4.58). These changes activate Cameron Street and create a stronger level of connection and permeability throughout the site which was otherwise compromised since the parking lot created a point of separation and perceived danger (at night). There are a total of nine 'clusters', each composed of a one-bedroom 'single' unit $\left(60 \mathrm{~m}^{2}\right)$, a two-bedroom 'single' unit $\left(110 \mathrm{~m}^{2}\right)$, a three-bedroom 'family' unit $\left(100 \mathrm{~m}^{2}\right)$, and a four-bedroom 'family' unit (140m $\left.{ }^{2}\right)$; an overall total of 36 dwelling units (see figures 4.63 to 4.66 ). This dwelling mix encourages the occupancy of a varied family dynamic that would also have a structured allotment of R-G-I as well as market rental occupants. 


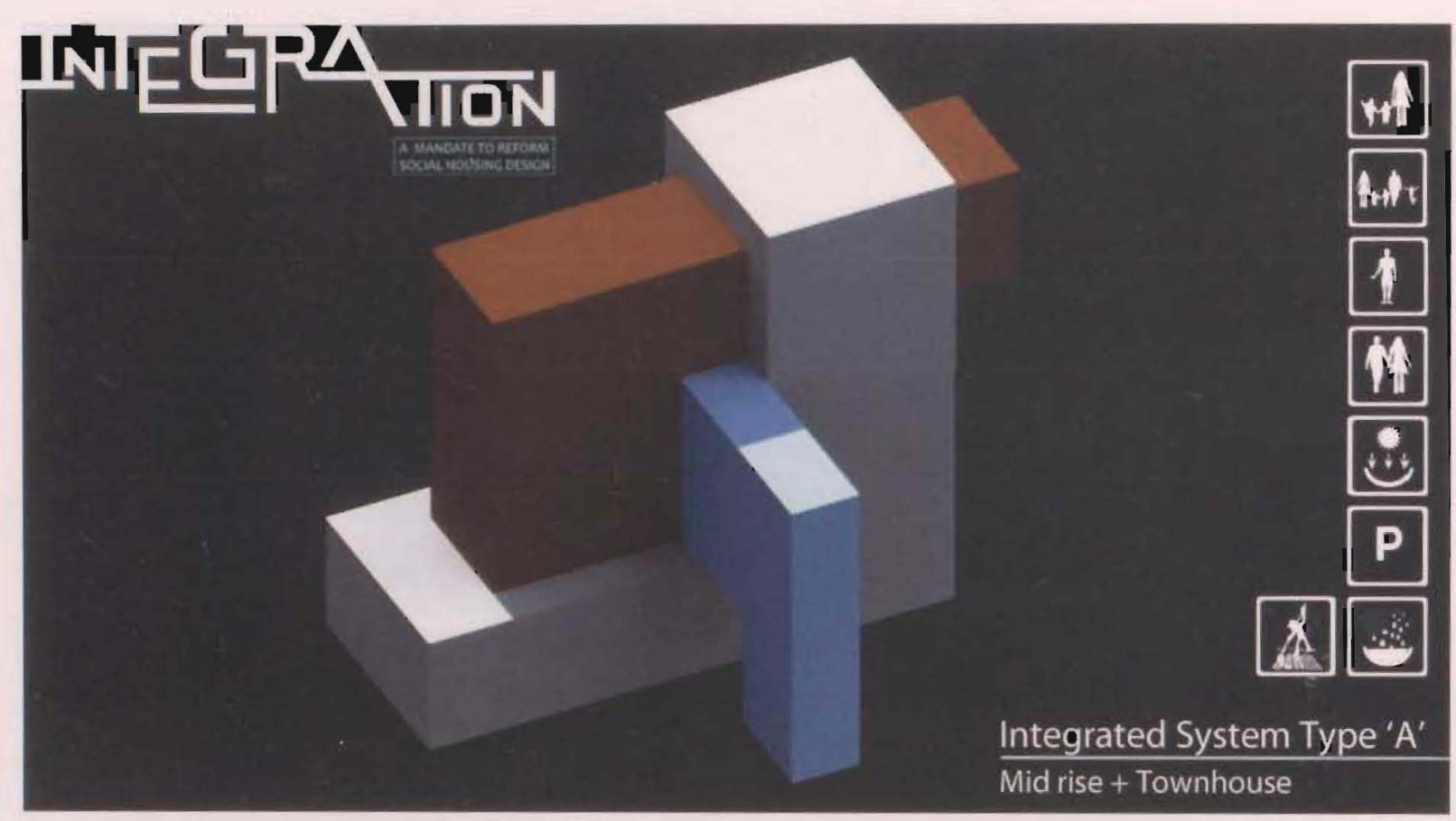

Figure 4.57. Parti Composition (Integrated System Type 'A')

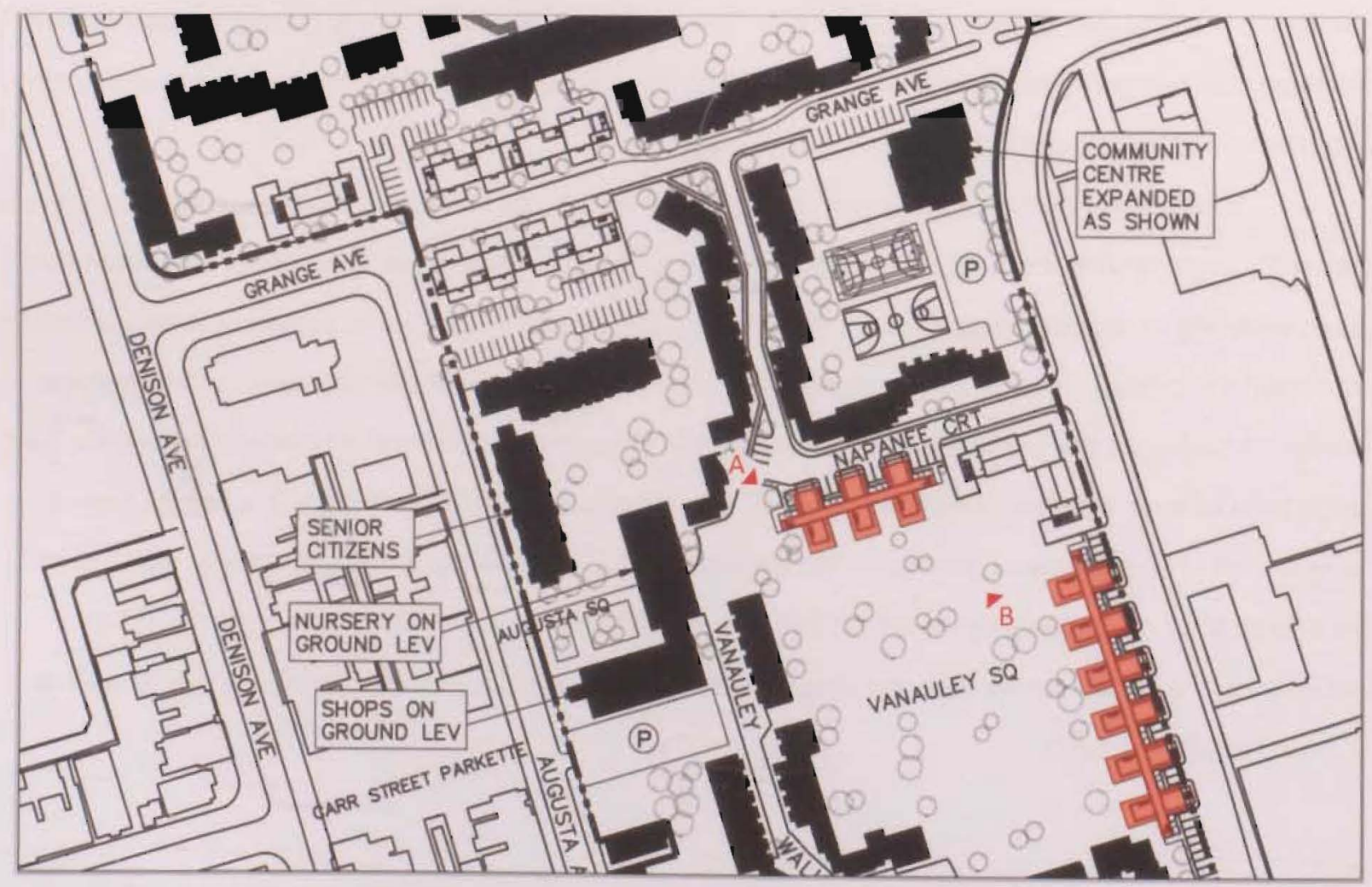

Figure 4.58. Part Site Plan 'A' 


\section{INECGR TION}

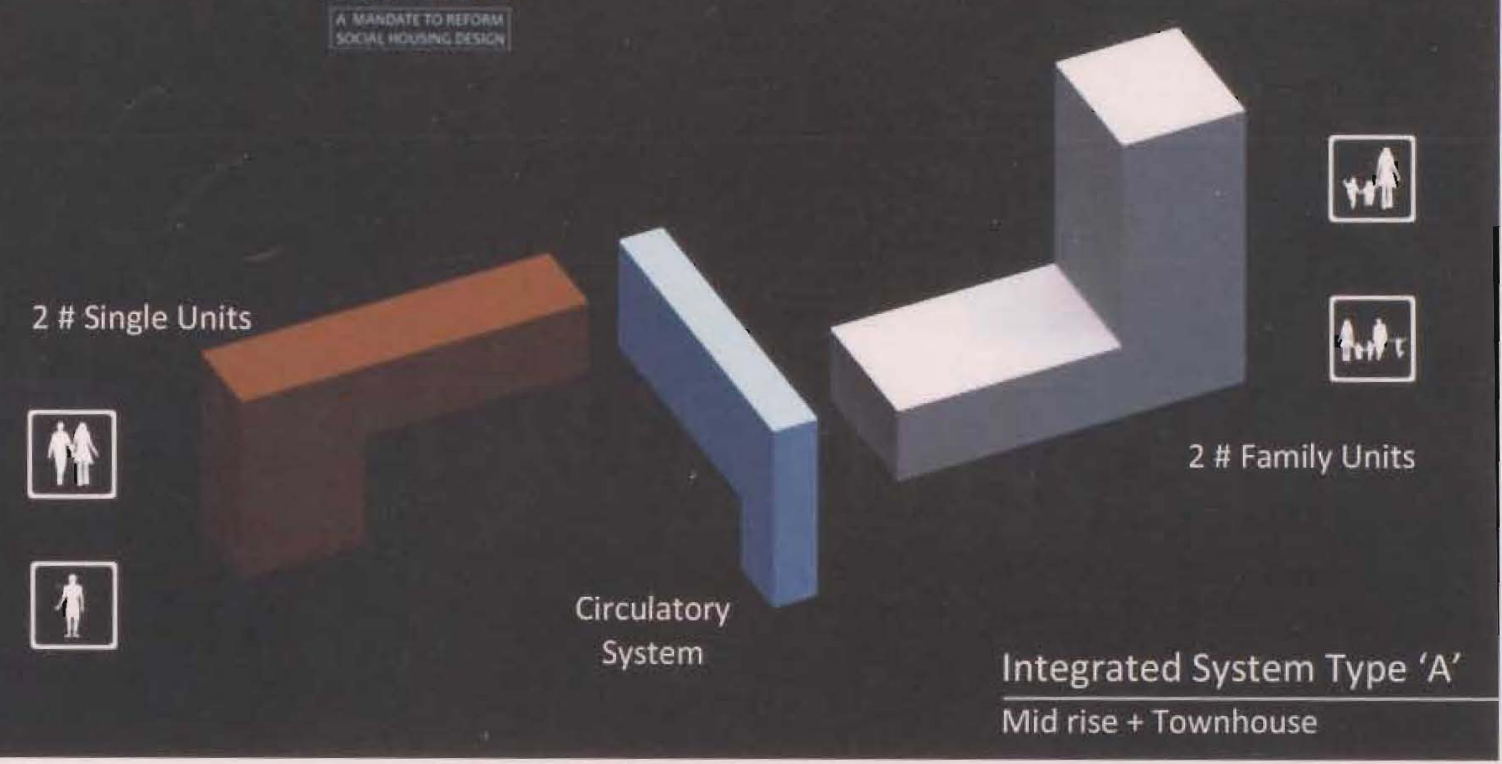

Figure 4.59. Parti Assembly (Integrated System Type 'A')

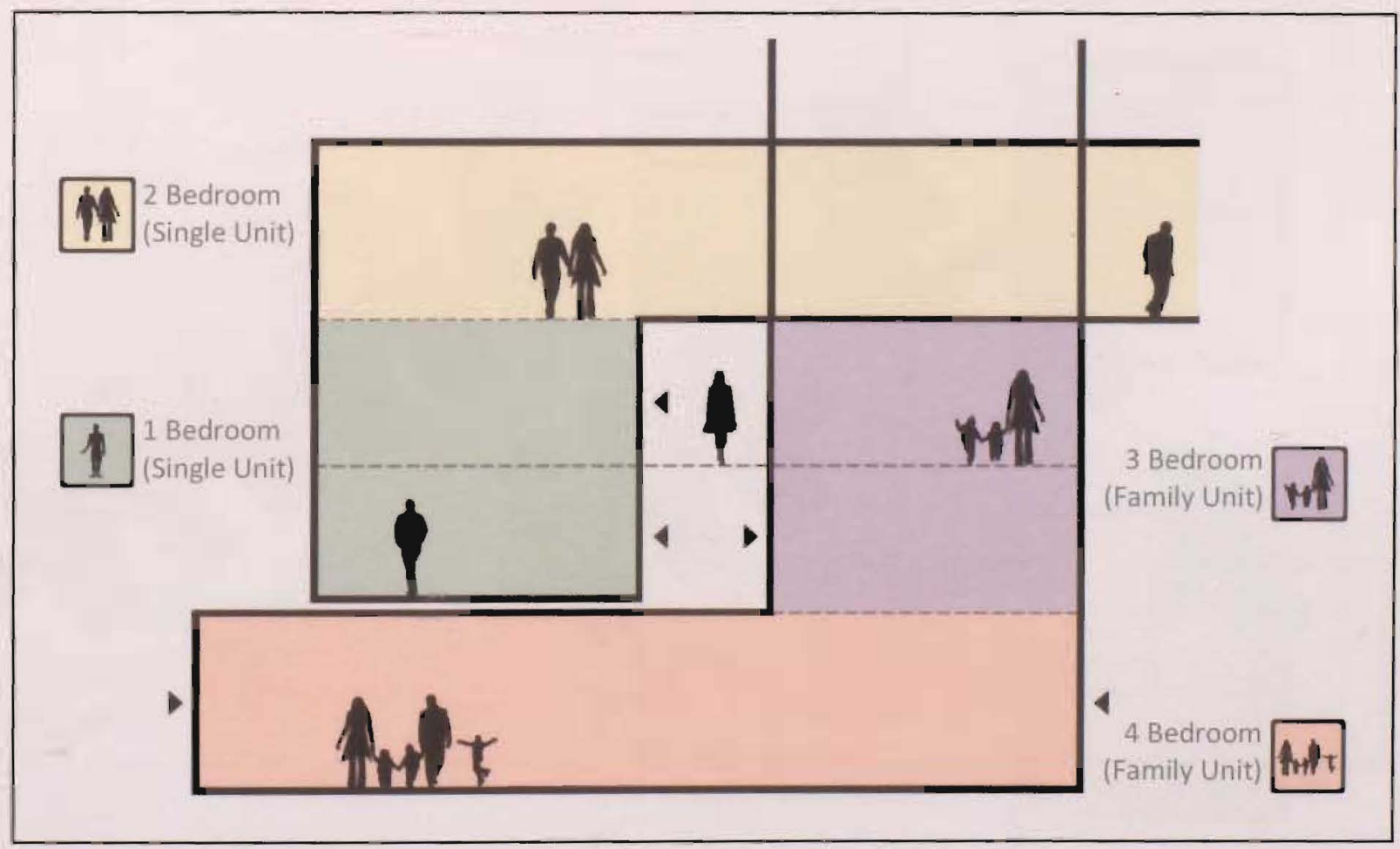

Figure 4.60. Schematic Section (Integrated System Type 'A') 


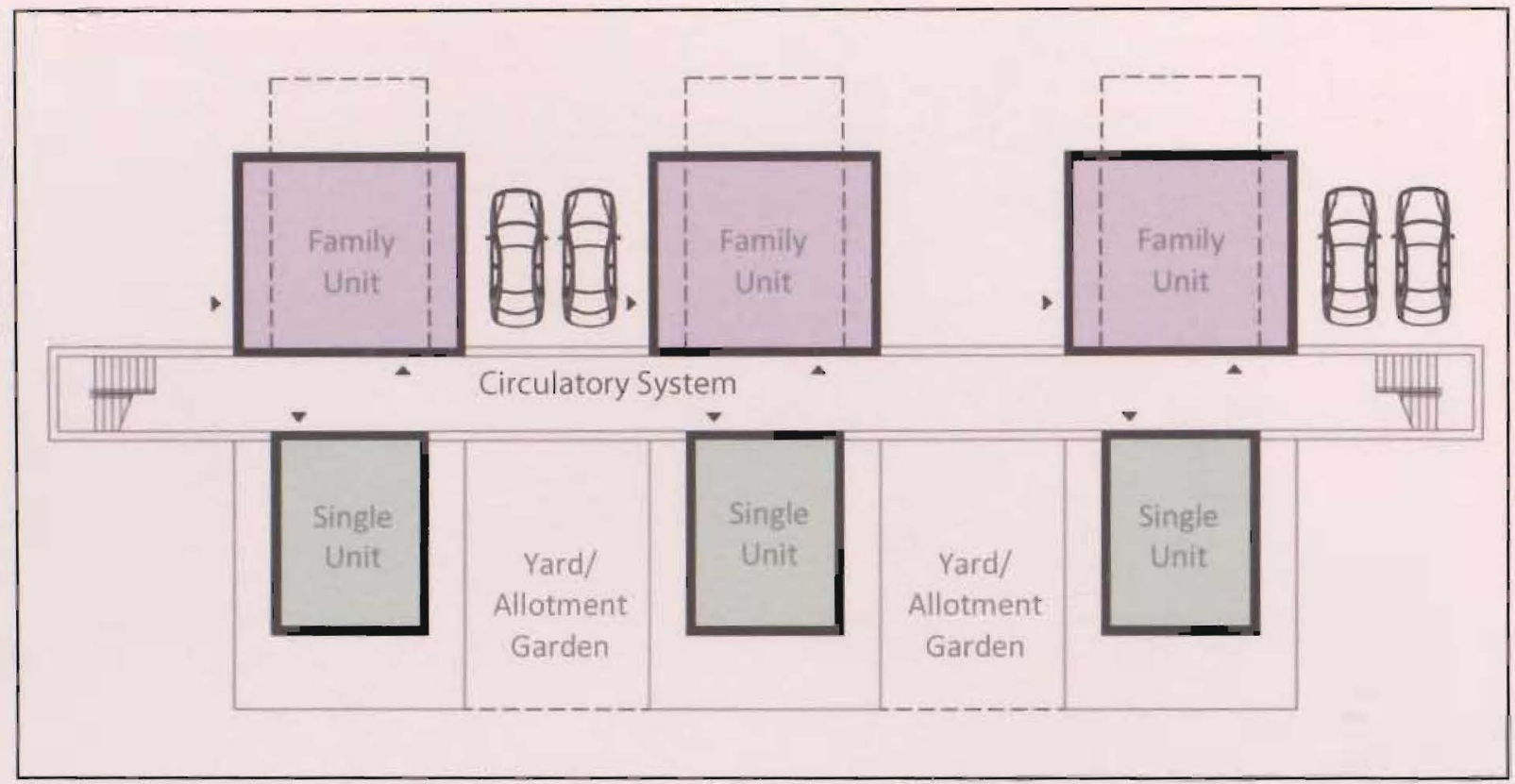

Figure 4.61. Schematic Layout (integrated System Type 'A')

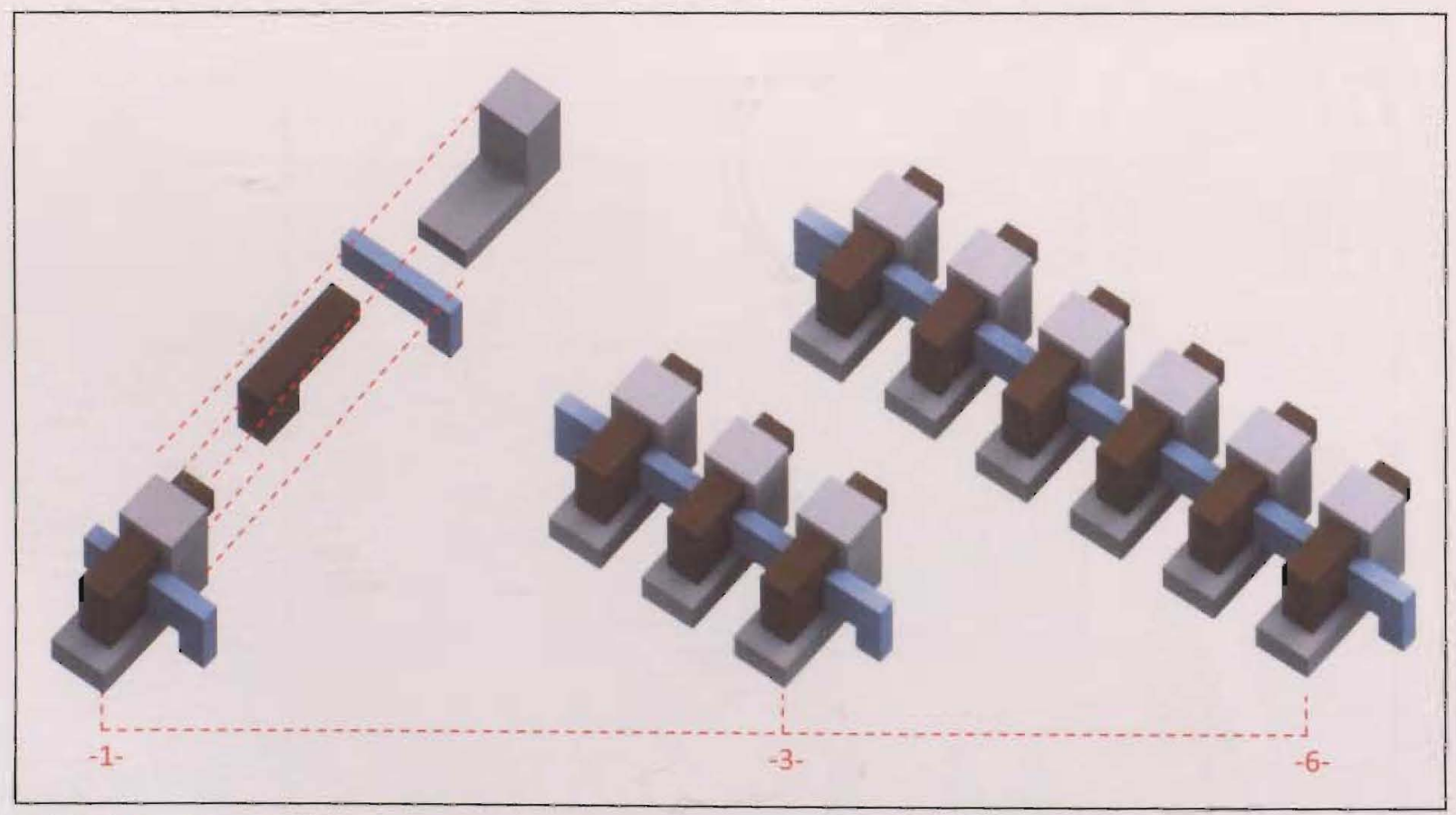

Figure 4.62. Permutations - Integrated System Type ' $A$ ' 

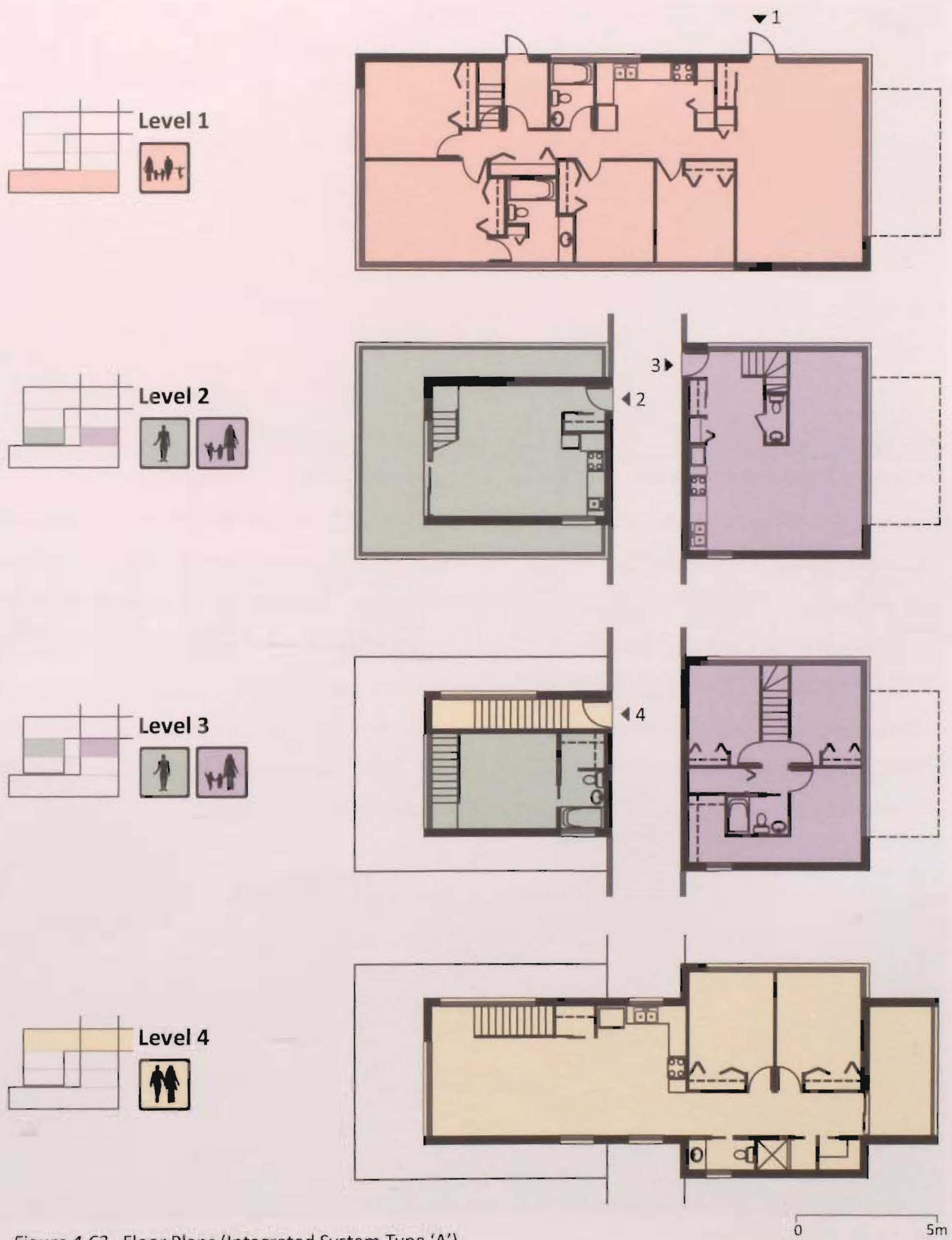

Figure 4.63. Floor Plans (Integrated System Type 'A') 


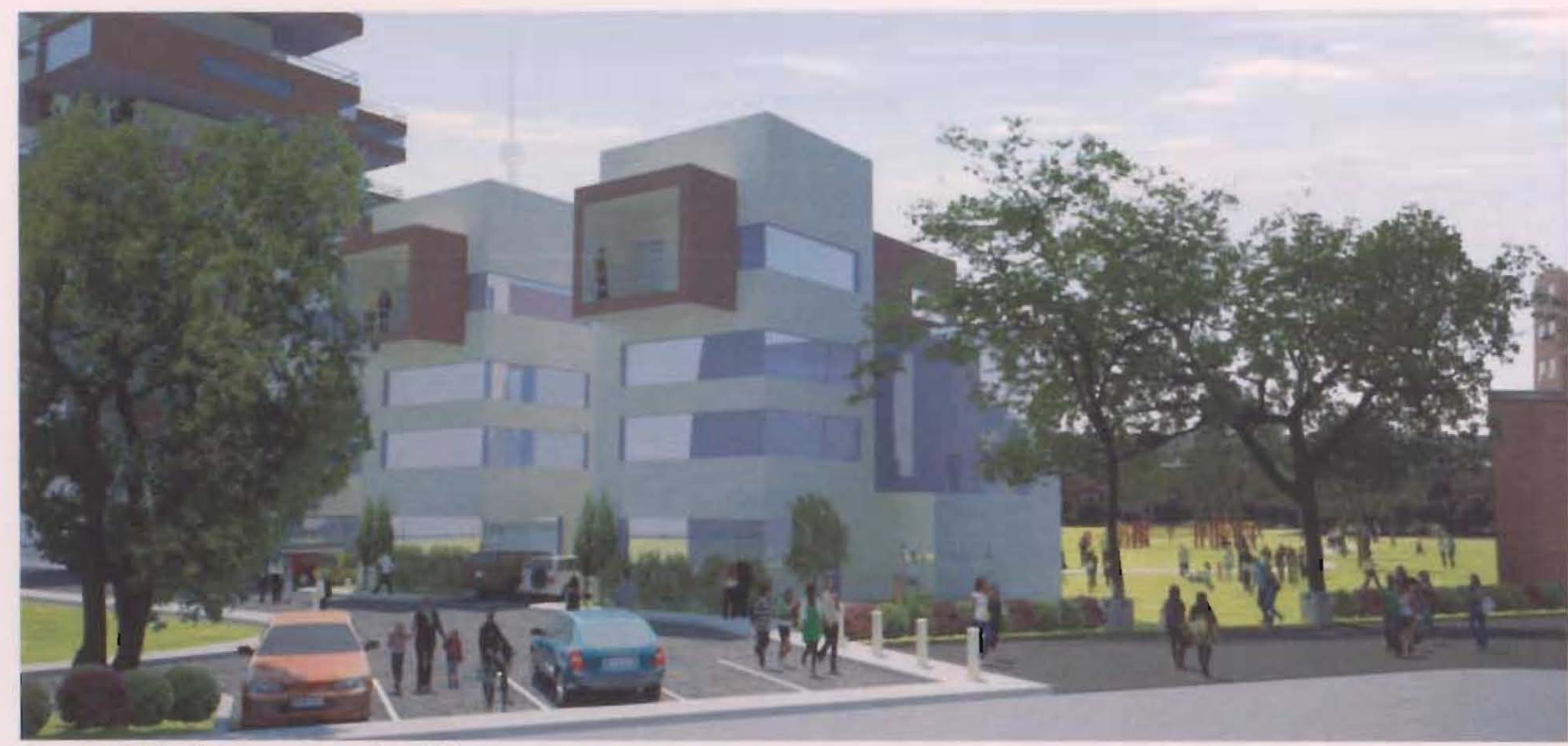

Figure 4.64. Perspective view 'A'
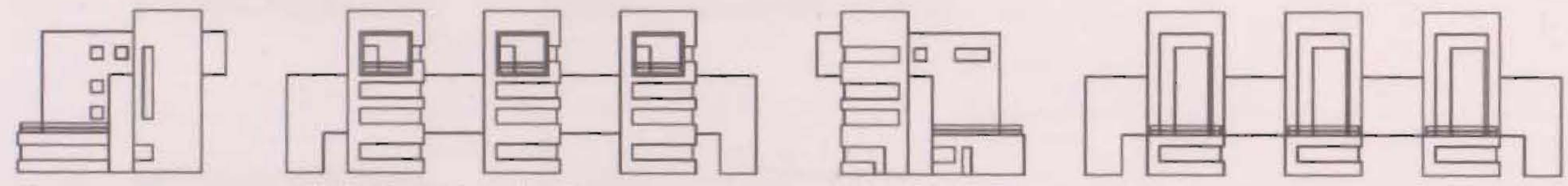

Figure 4.65. Integrated System Type 'A' Elevations

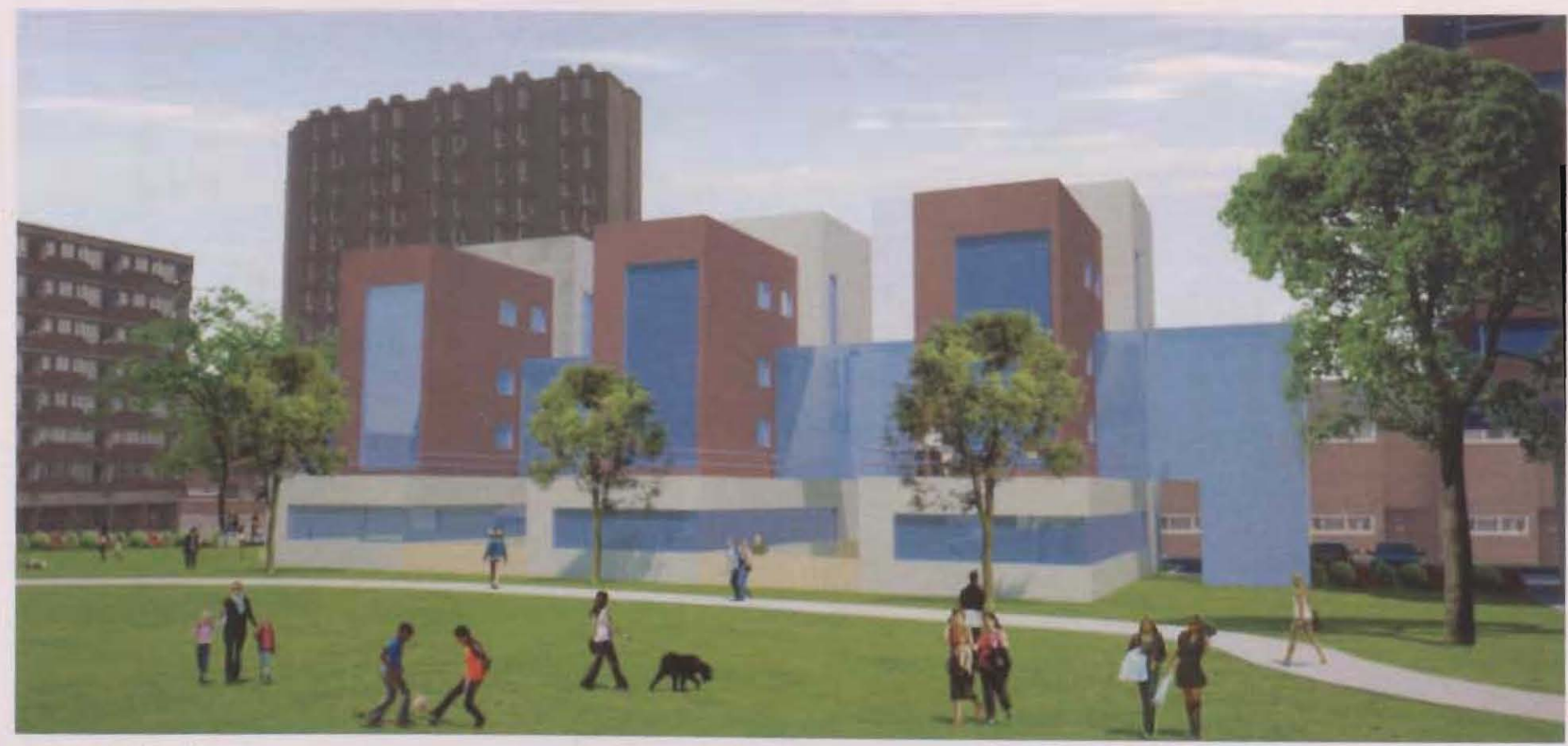

Figure 4.66. Perspective view ' $B$ '

Past - Present - Future: The Revitalization of Social Housing in Canada 


\section{INTEGPIION \\ A MANDATE TO REFORM SOCIAL HOUSING DESIGN \\ Integrated System Type 'B'}

Theoretically, the Integrated System Type ' $B$ ' concept is a hybrid design, comprising a mid rise building typology and commercial/retail space. This design approach to urban housing has been implemented for some time and will continue to flourish as it has proved to be a successful method of intervention. Successes include the creation of jobs and business opportunities for residents and nonresidents alike, the convenience of shops/restaurants etc. within walking distance of residences, and the 18 to 24 hour activation of the street that will improve both inward and outward connectivity.

The design is essentially a fusion between a single occupancy unit ( 1 bedroom unit), a family occupancy unit ( 3 bedroom unit) both on the upper level, and a 'flexible' commercial space at grade (see figures 4.67 to 4.70 ). Since the dwelling units have been elevated to allow for commercial activity below, the 'family' units are spaced $6 \mathrm{~m}$ apart to accommodate a private yard/allotment garden for each unit. Each 'single' unit contains its own integrated balconies (see figures 4.71 to 4.74 ). The circulatory system is a heavily glazed, double-loaded corridor that generates electricity through its photovoltaic coating, and draws daylight into its corridors as a result of its design and materiality. The commercial space at grade is divided into four 'flex' spaces that can support various activities such as live/work spaces, shops, cafes etc. It also encourages the occupancy of lower traffic (vehicular) businesses such as craft/wood shops, artist spaces which would mitigate the risk of congesting surrounding streets.

This Integrated System Type ' $B$ ' has been introduced to Alexandra Park as a single housing block along Dundas Street West and two housing blocks along Grange Avenue (fig. 4.68). Each building sits where there was once a parking lot. All have been strategically placed in 'high activity zones' that can support commercial activity. There are a total of three housing blocks, each composed of 4 onebedroom 'single' units $\left(75 \mathrm{~m}^{2}\right.$ each) and 4 three-bedroom 'family' units ( $115 \mathrm{~m}^{2}$ each); an overall total of 24 dwelling units. This dwelling mix encourages the occupancy of a varied family dynamic that would also have a structured allotment of $\mathrm{R}-\mathrm{G}+\mathrm{t}$ as well as market rental occupants. 


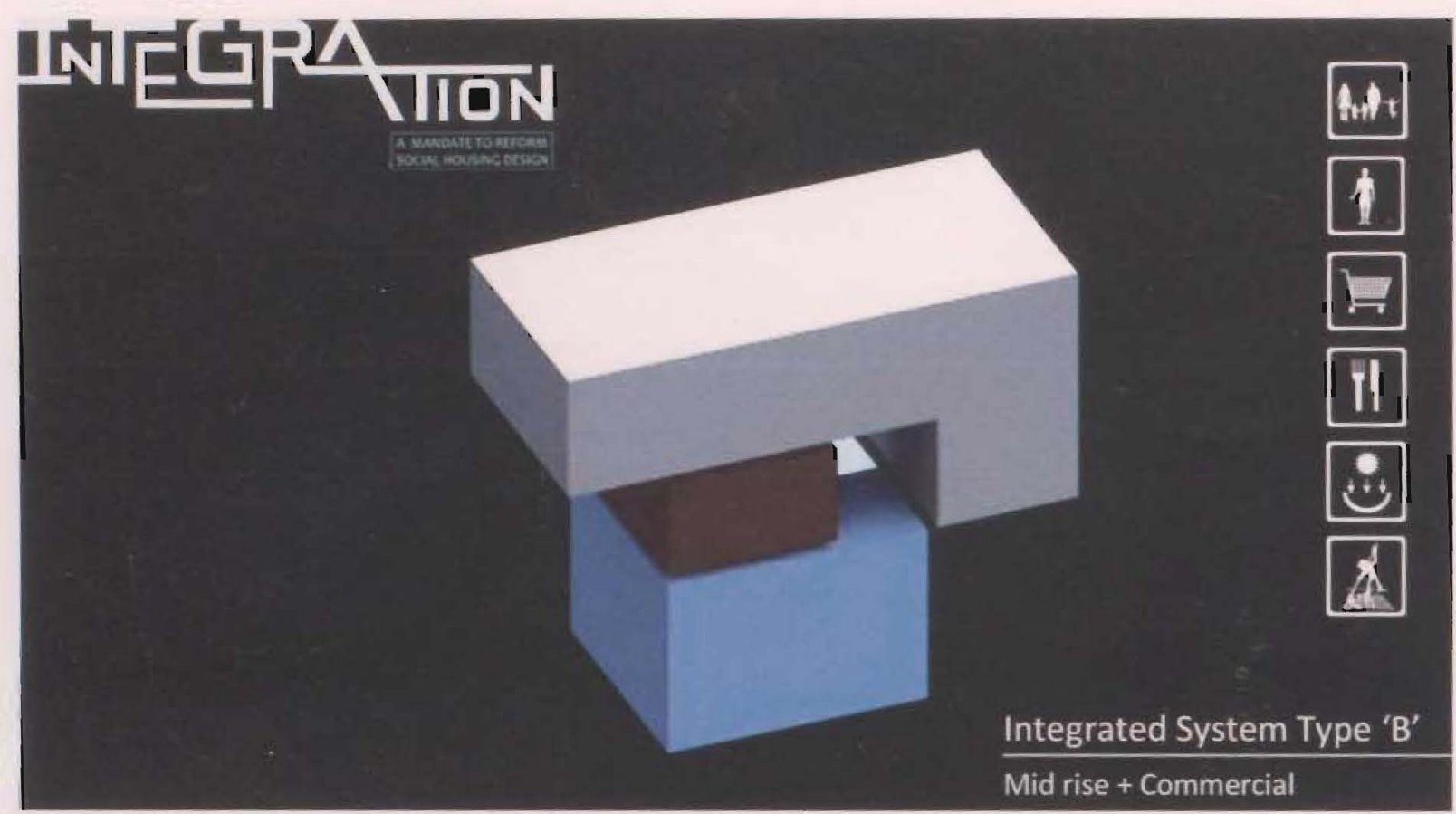

Figure 4.67. Parti Composition (Integrated System Type 'B')

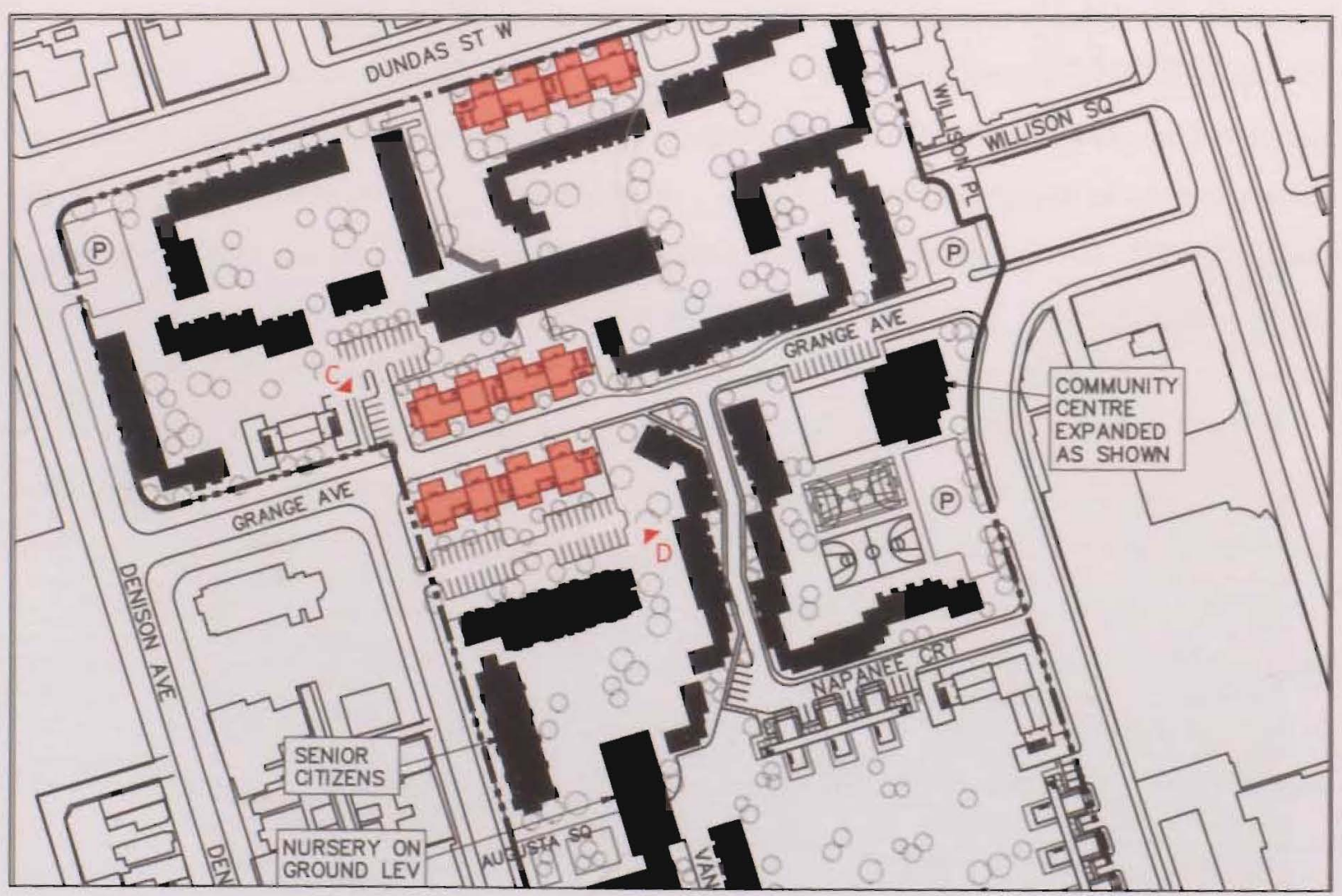

Figure 4.68. Part Site Plan ' $B$ ' 


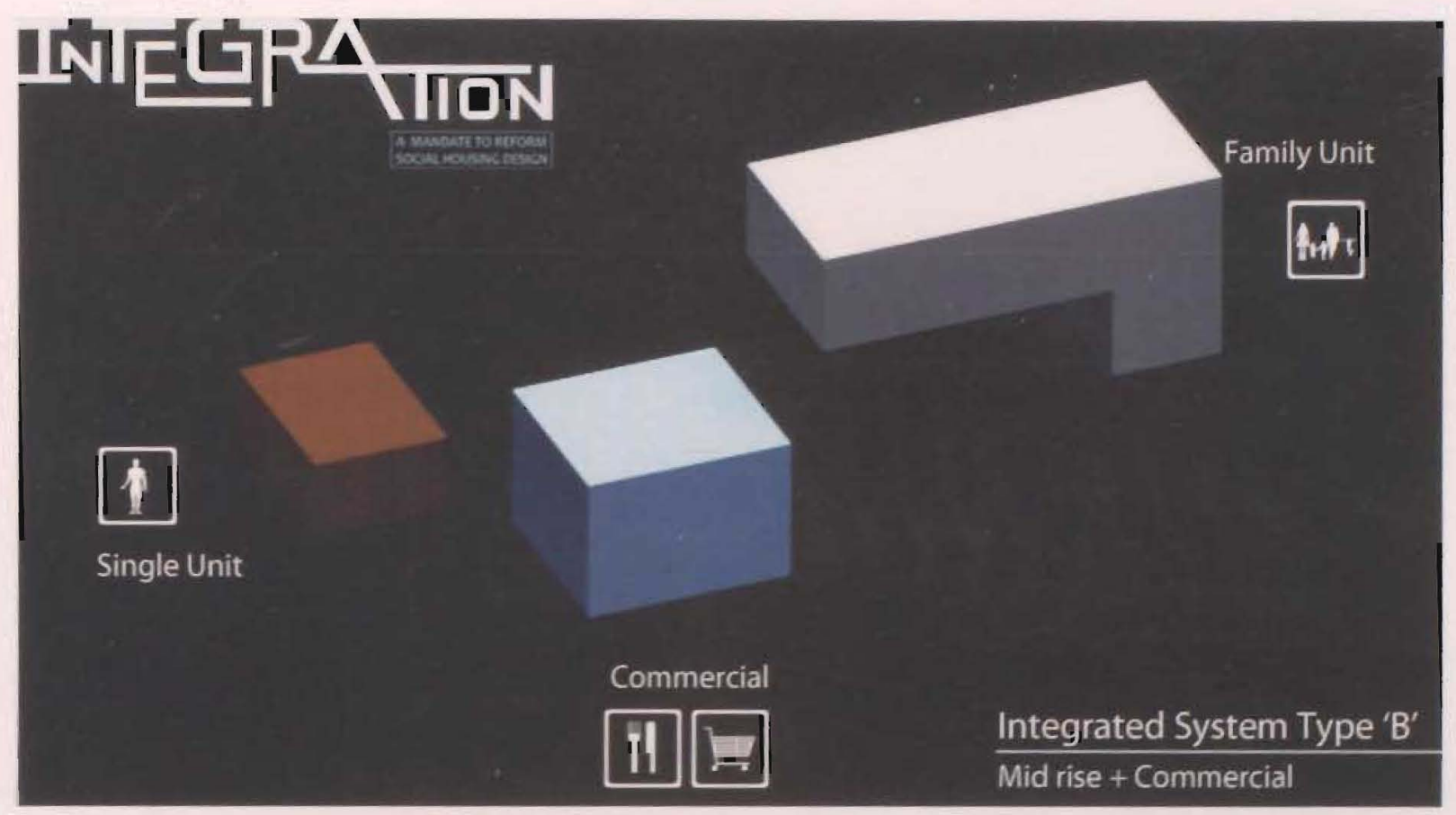

Figure 4.69. Parti Assembly (Integrated System Type 'B')

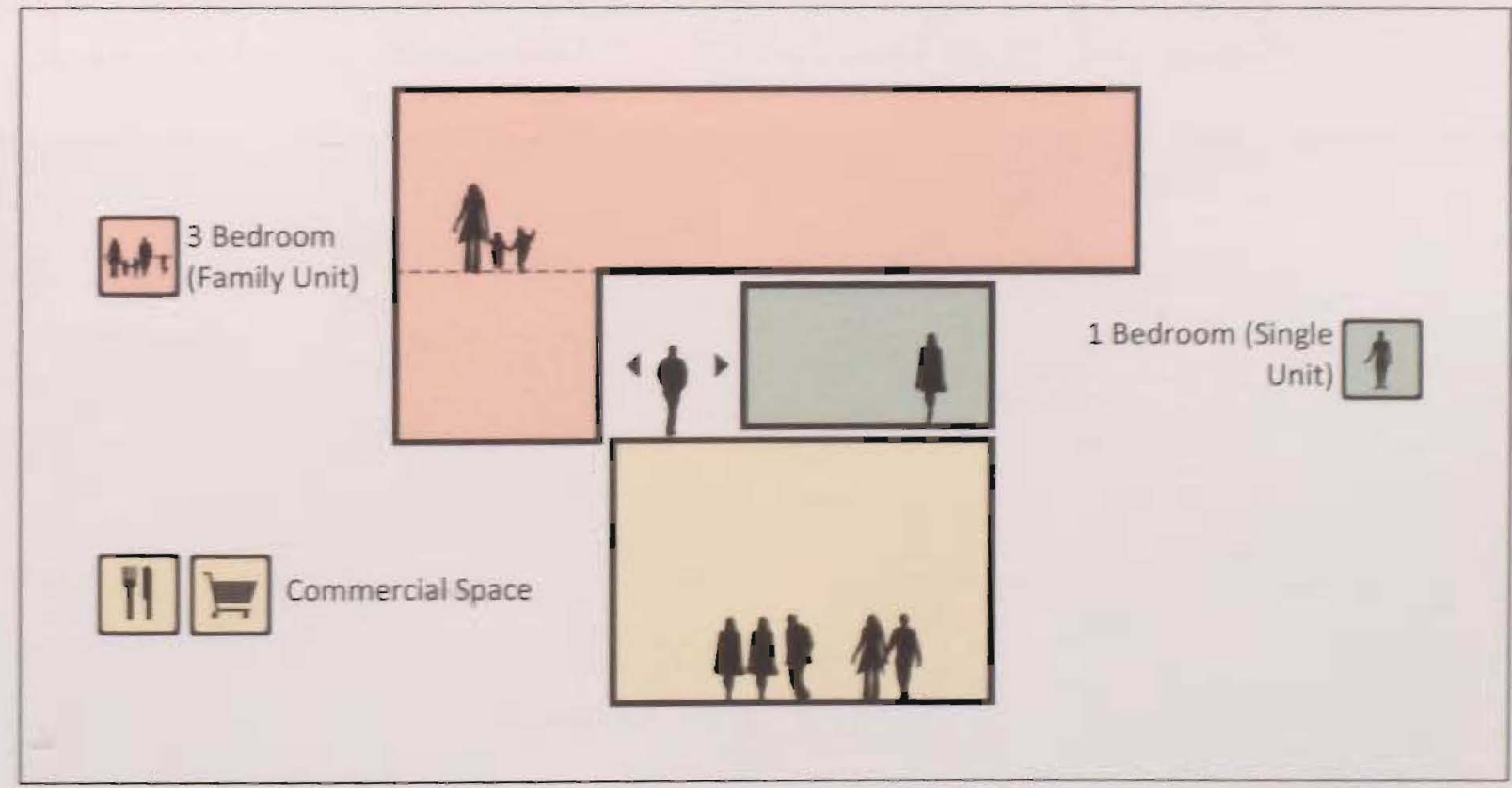

Figure 4.70. Schematic Section (Integrated System Type ' $B$ ') 


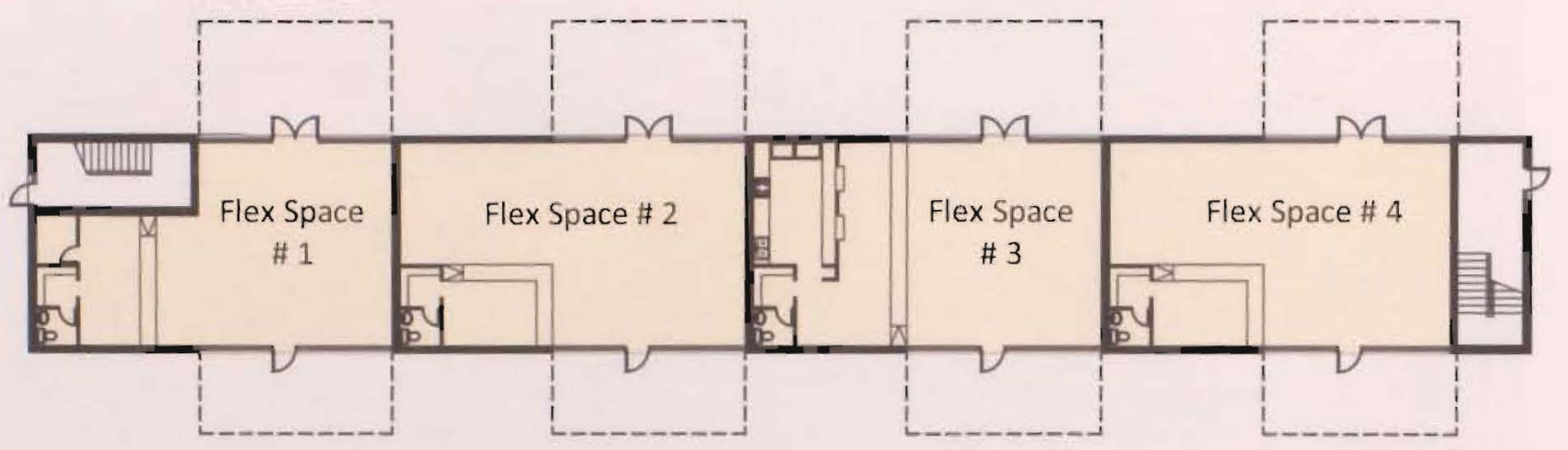

Level 1
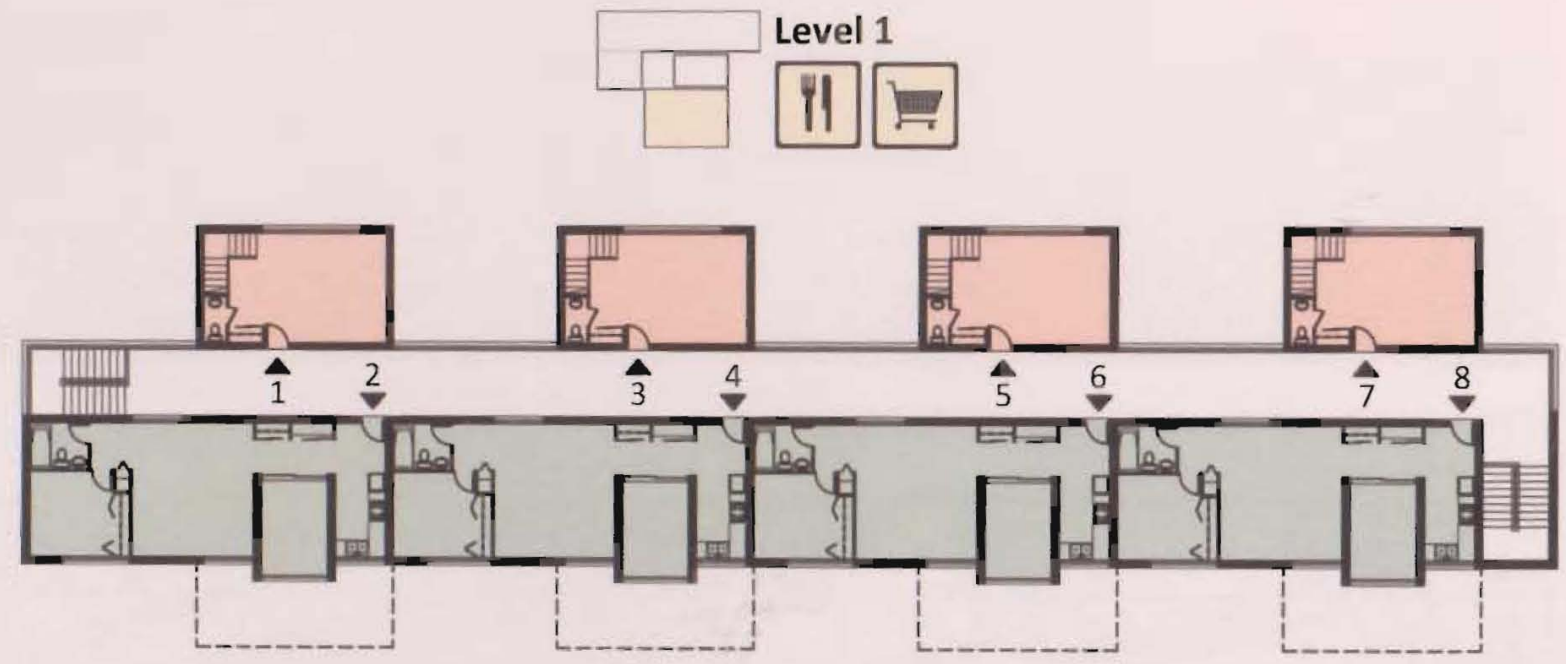

Level 2
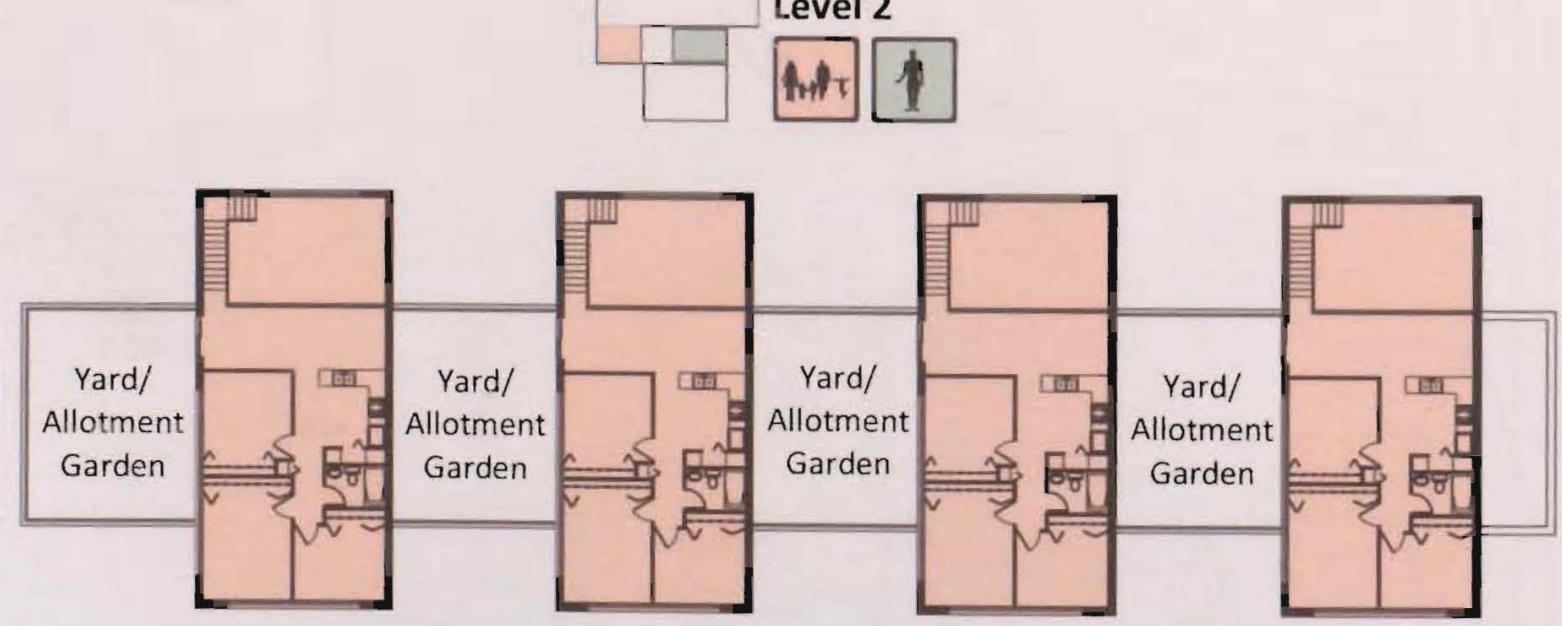

Figure 4.71. Floor Plans

(Integrated System Type 'B')

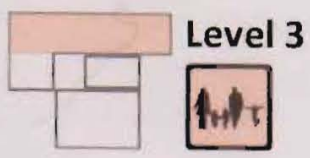

Level 3

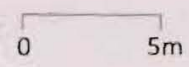




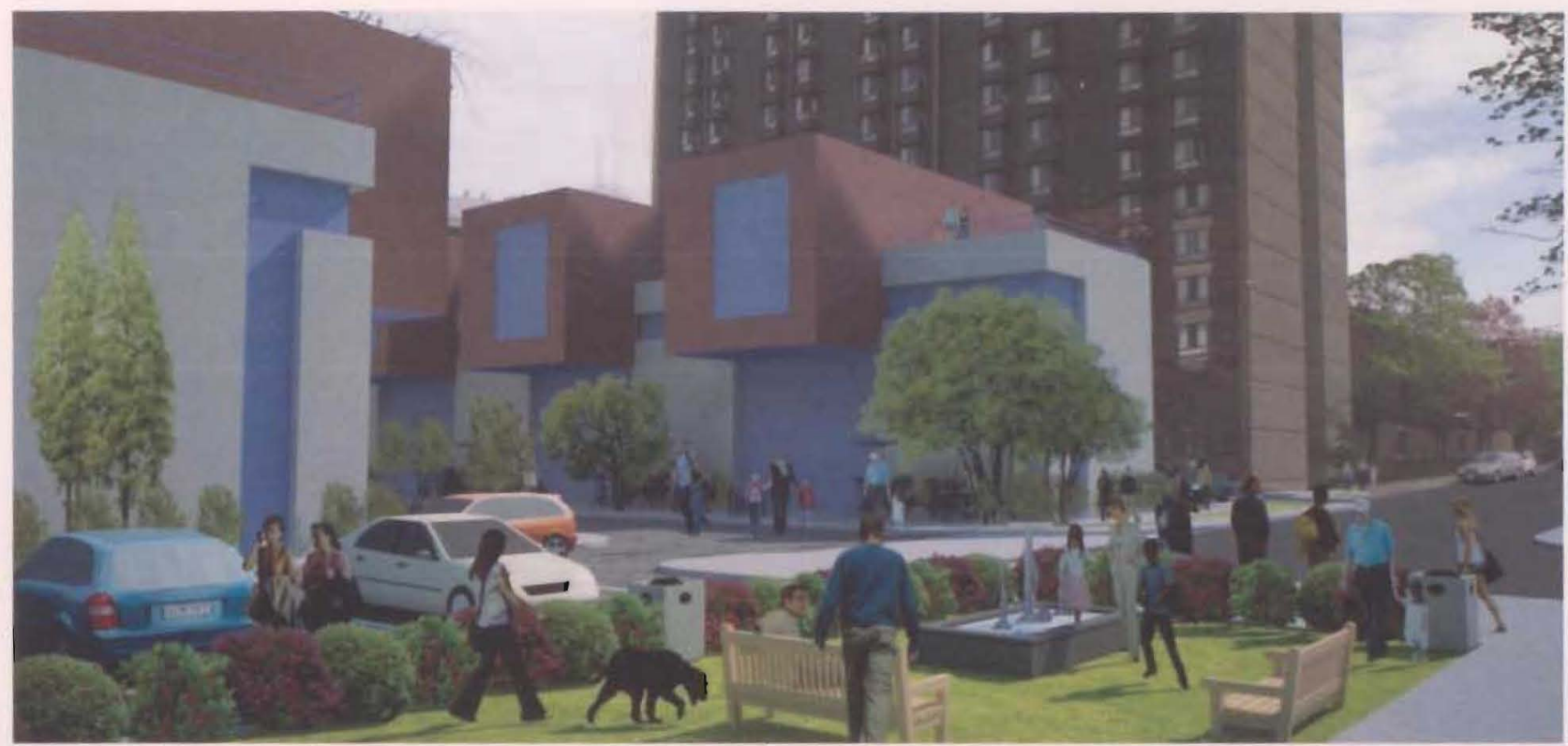

Figure 4.72. Perspective view ' $C$ '

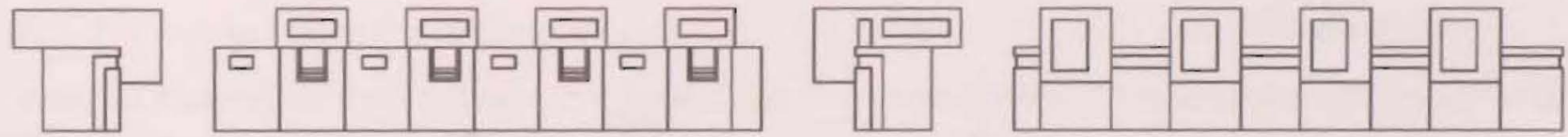

Figure 4.73. Integrated System Type 'B' Elevations

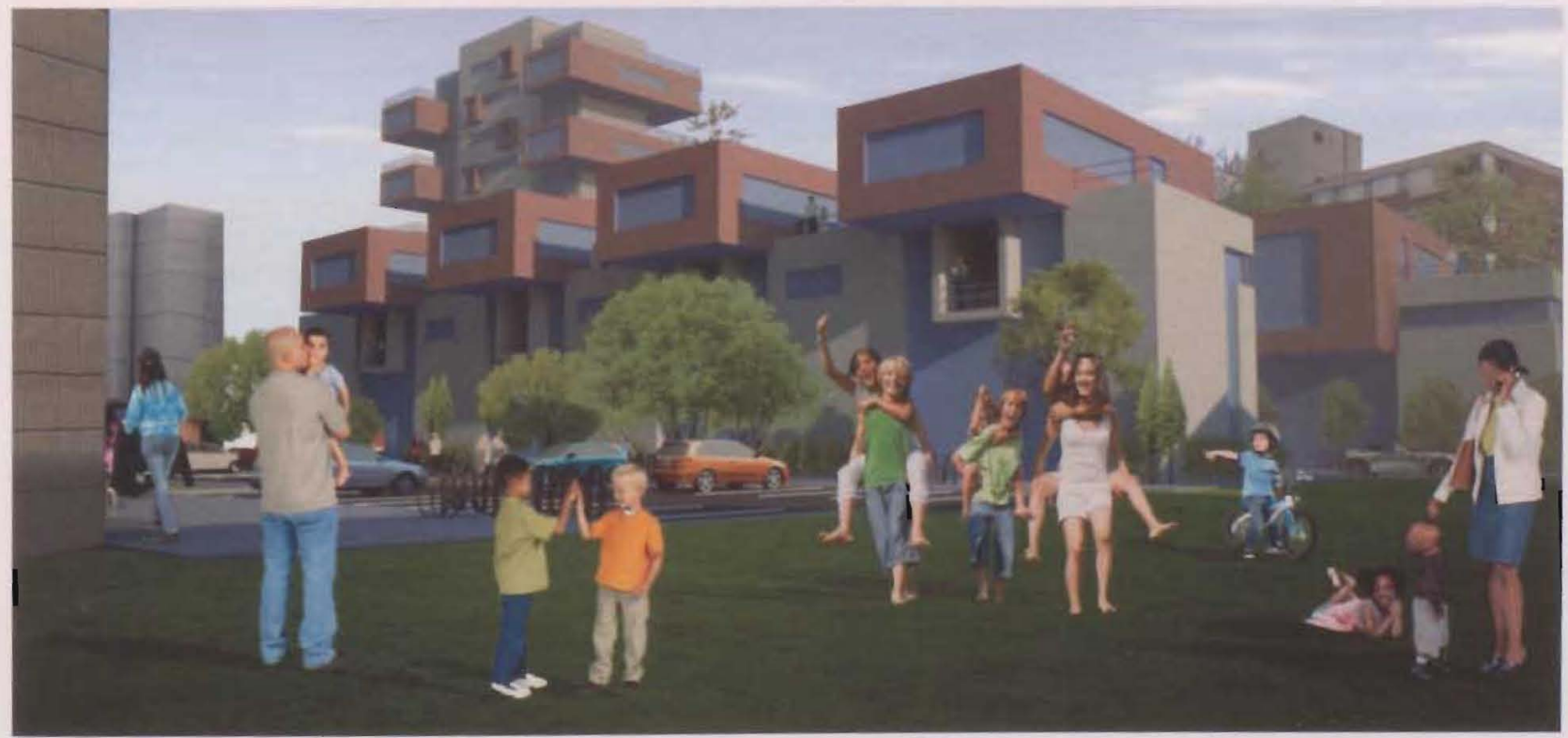

Figure 4.74. Perspective View ' $D$ ' 


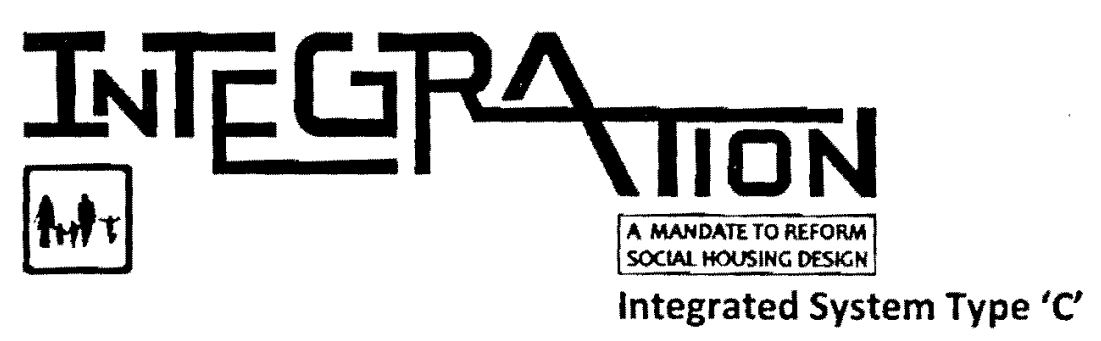

Theoretically, the Integrated System Type ' $C$ ' concept is a hybrid design, composed of a high rise housing typology and a single occupancy townhouse. As mentioned earlier, this design approach accounts for the density requirements of the high rise within an urban context while incorporating elements of privacy and sustainability typical to townhouse design.

The design is essentially a central, vertical block of single occupancy units ( 1 bedroom units) with an interrupted, vertical array of family occupancy units ( 3 bedroom units) which cantilever on either side of the central block. A double storey commercial space occurs at grade and provides an activated connection to the street (see figure 4.75). Since the dwelling units have been elevated to allow for commercial activity below, the 'family' units are vertically separated to accommodate a private yard/allotment garden for each unit and 'single' units each contain their own integrated balcony (see figures 4.77 and 4.81). The circulatory system is a heavily glazed, split, vertical shaft that generates electricity through its photovoltaic coating and draws daylight into these spaces as a result of its design and materiality.

This Integrated System Type ' $C$ ' has been introduced to Alexandra Park along Grange Avenue where a near-derelict apartment building once existed and the intersection between Napanee Crescent and Cameron Street (see figure 4.76). Not only does this approach activate the street realm, it also creates instances of high density blocks that allow developments such as the expansion of Vanauley Square, to occur without compromising the number of dwellings per hectare. Between the two tower blocks introduced on site, there is a total of 70 one-bedroom 'single' units (67 $\mathrm{m}^{2}$ each), and 20 threebedroom 'family' units ( $100 \mathrm{~m}^{2}$ each); an overall total of 90 dwelling units. This dwelling mix encourages the occupancy of a varied family dynamic that would also have a structured allotment of R-G-I as well as market rental occupants.

Past - Present - Future: The Revitalization of Social Housing in Canada 


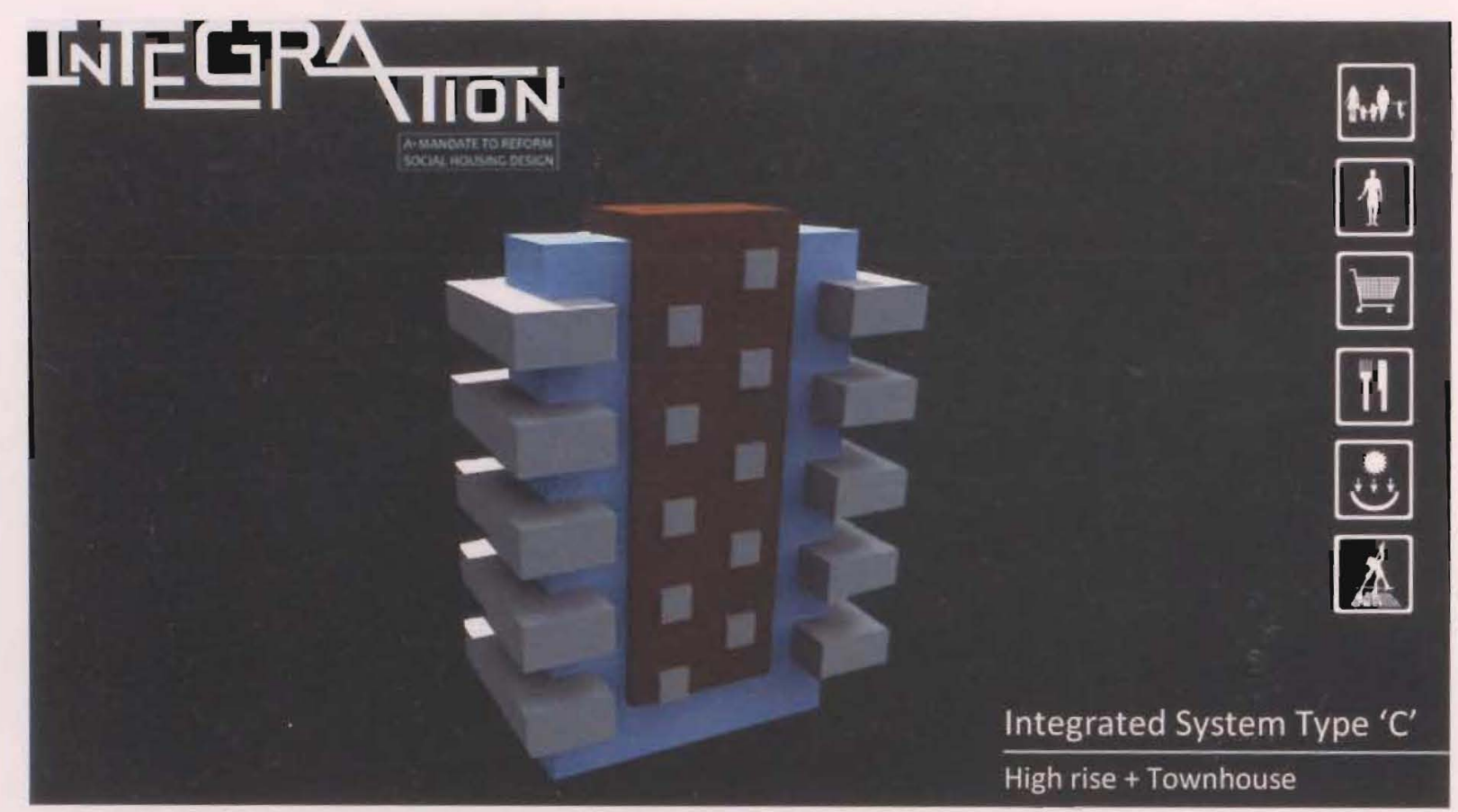

Figure 4.75. Parti Composition (Integrated System Type ' $C$ ')

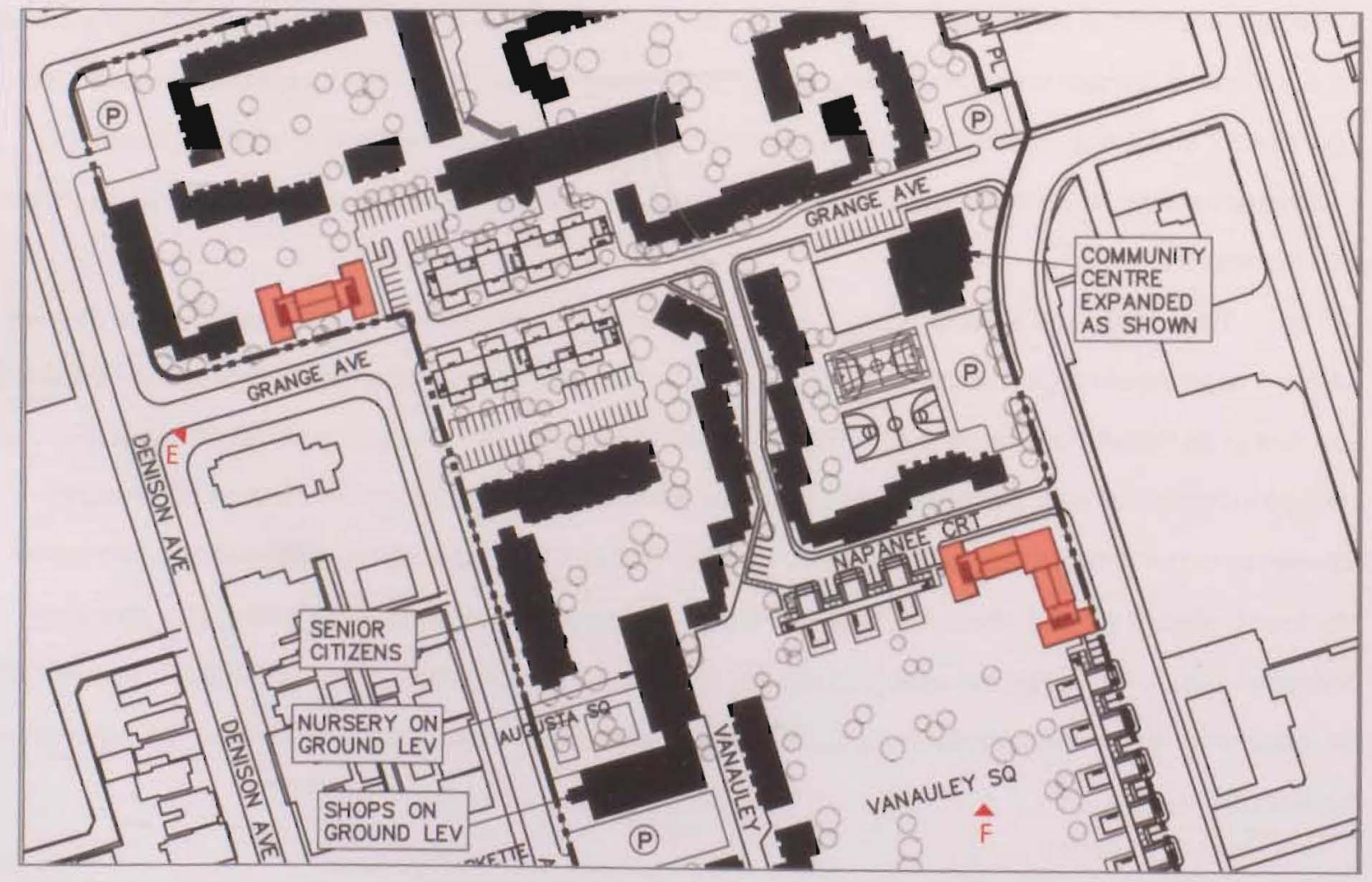

Figure 4.76. Part Site Plan ' $\mathrm{C}$ ' 


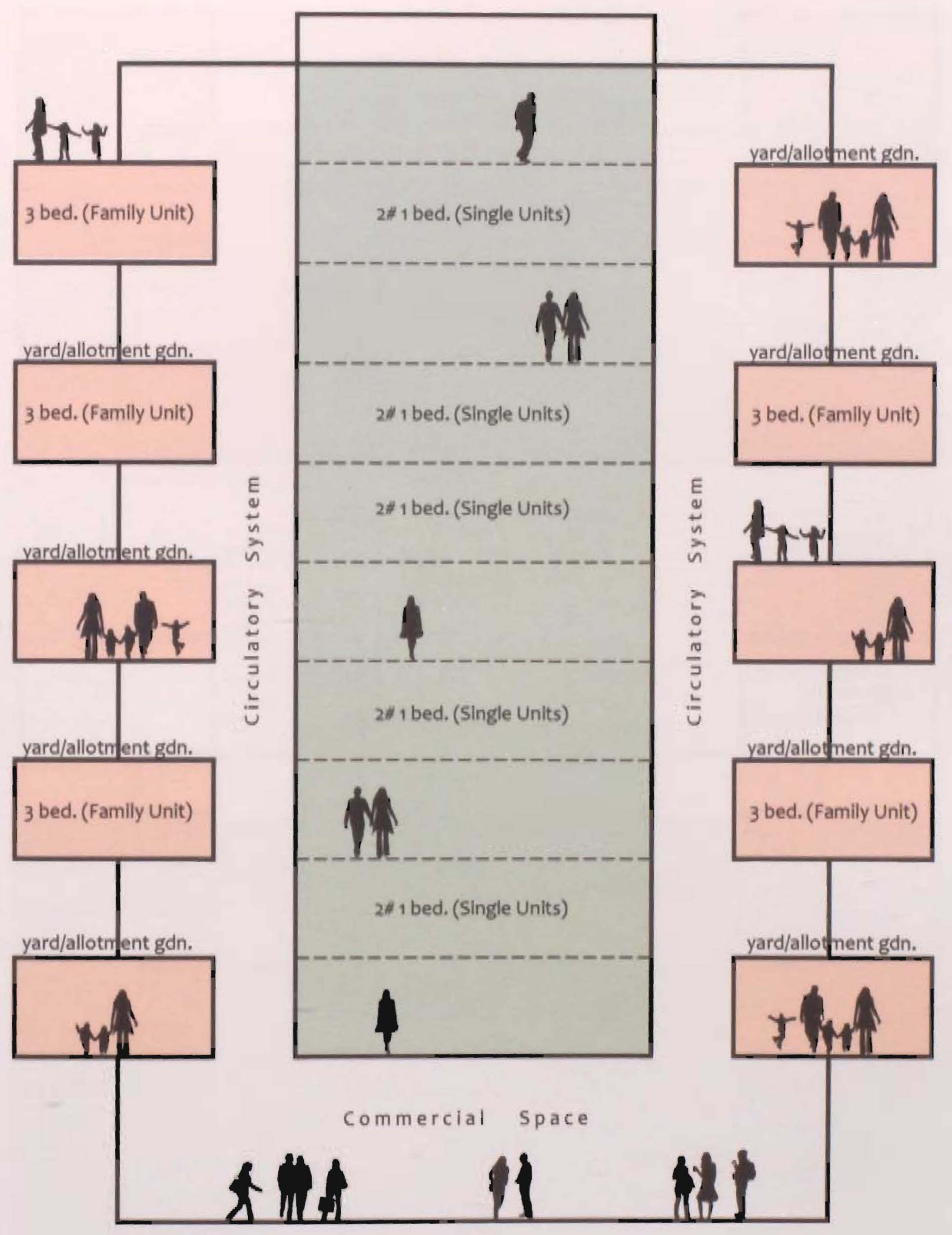

Figure 4.77. Schematic Section (Integrated System Type ' $C$ ')

Past - Present - Future: The Revitalization of Social Housing in Canada 

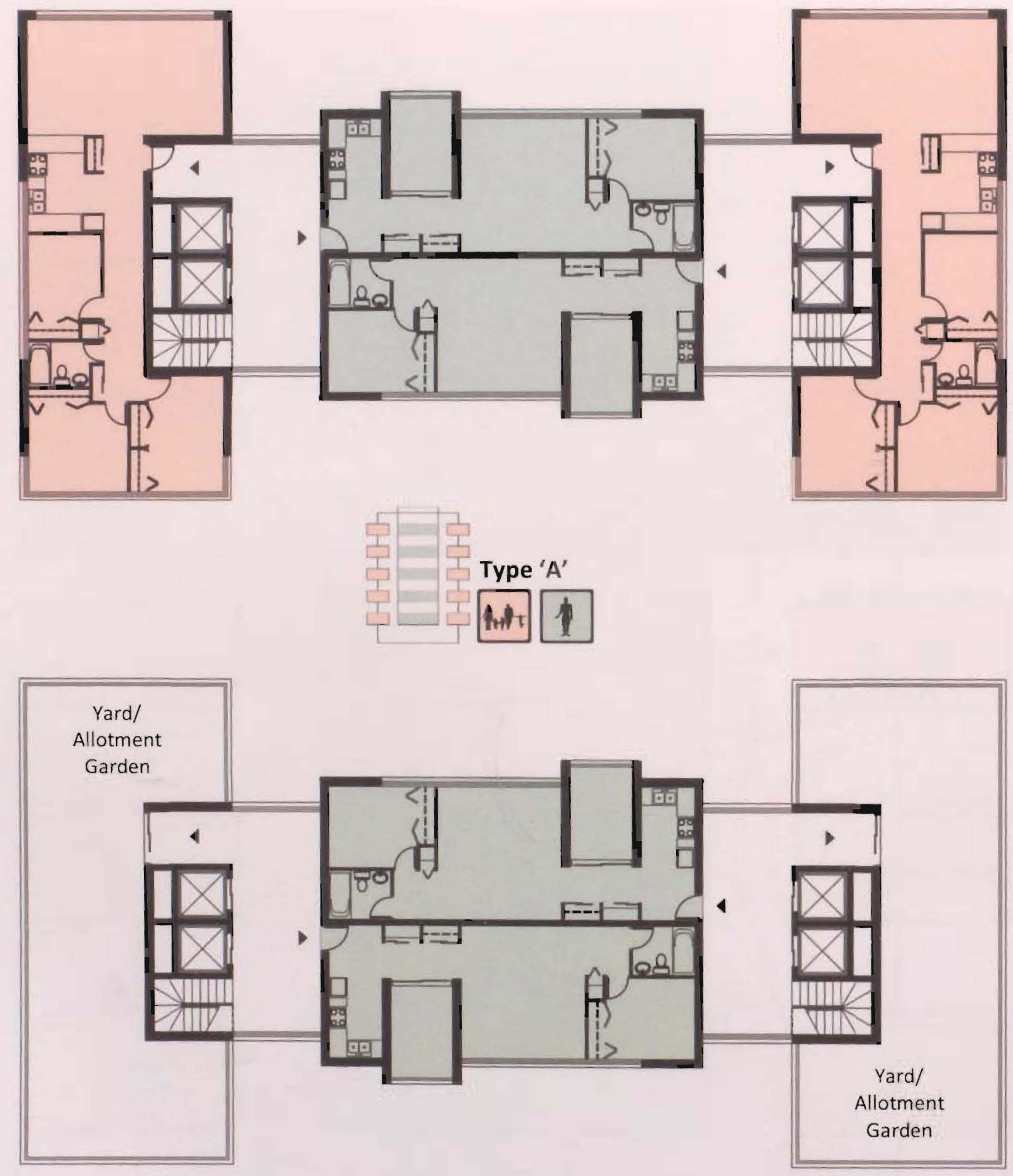

Figure 4.78. Floor Plans

(Integrated System Type ' $C$ ')

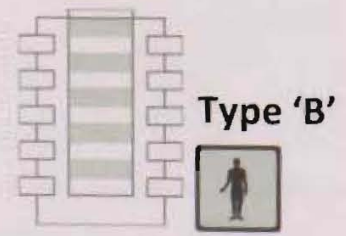

Past - Present - Future: The Revitalization of Social Housing in Canada 


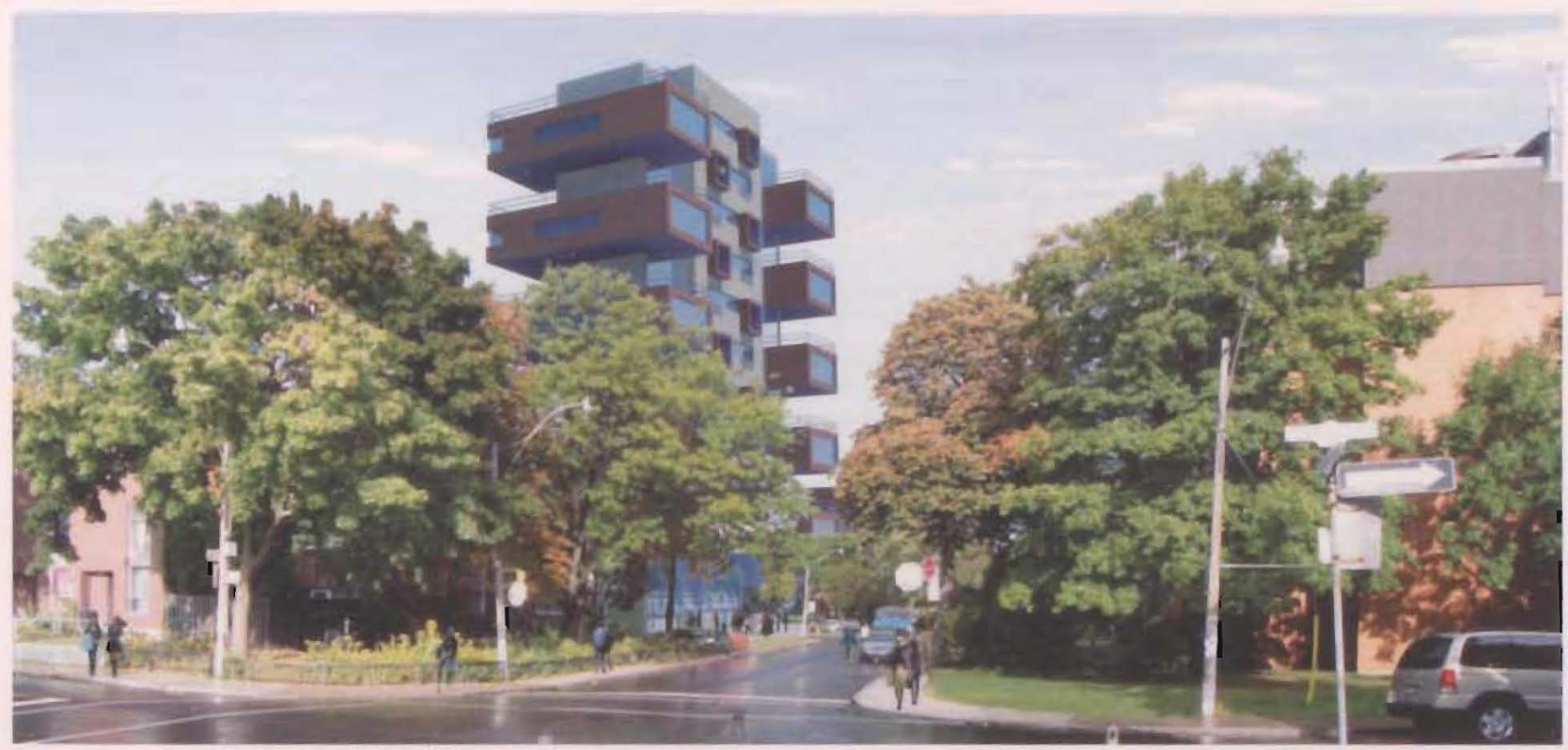

Figure 4.79. Perspective View ' $\mathrm{E}$ '
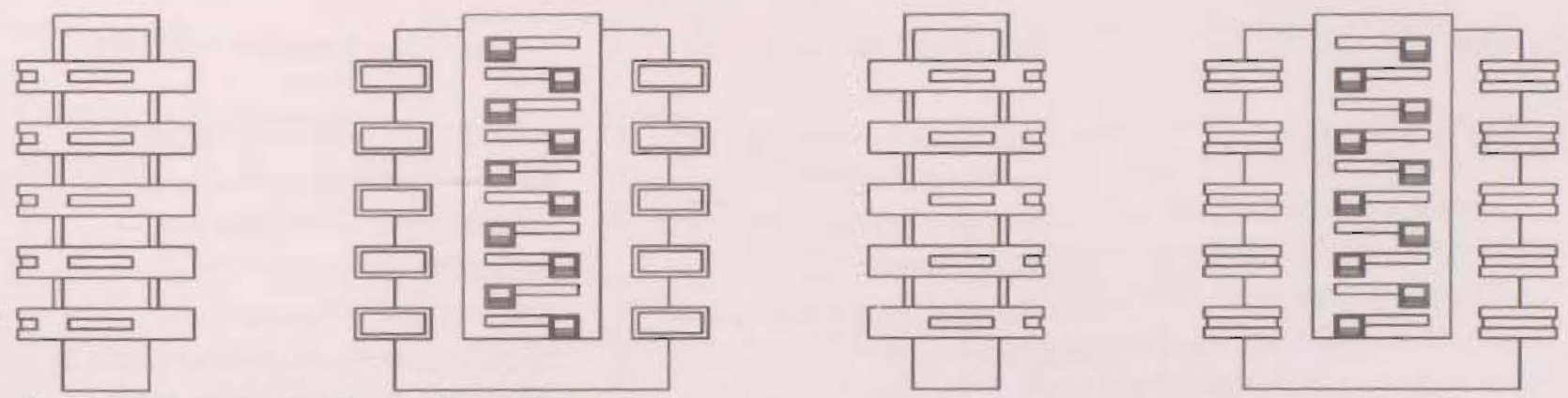

Figure 4.80. Integrated System Type ' $C$ ' Elevations

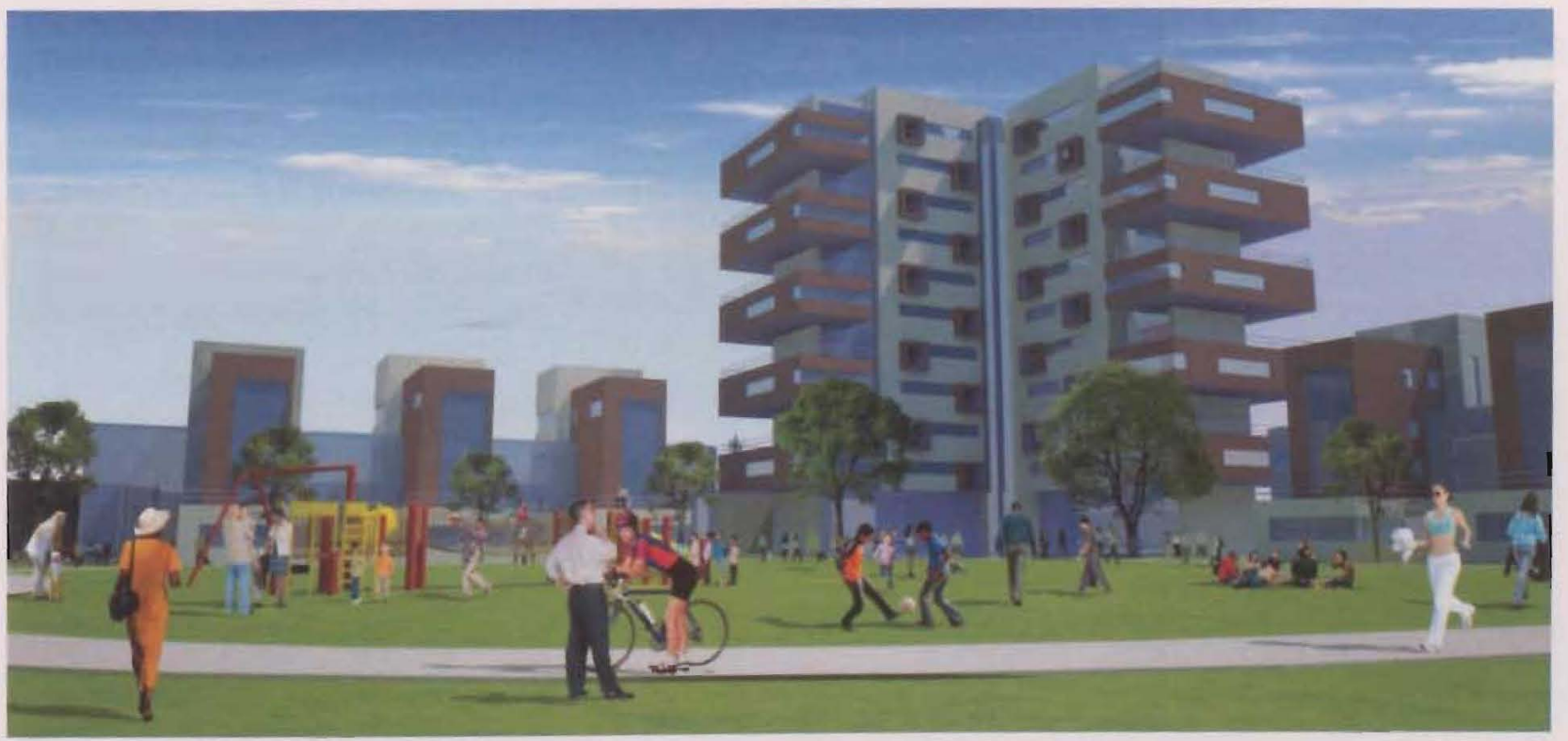

Figure 4.81. Perspective View ' $F$ '

Past - Present - Future: The Revitalization of Social Housing in Canada 


\section{Alexandra Park - Comparative Data Analysis}

In order to measure the success of architectural prowess, one must initially compare it against the entity from which it was derived. Subsequently, it would be important to monitor its use over time to determine the success of implementation. The following quantitative data provides a comparative analysis of the existing conditions and proposed revitalization of Alexandra Park (see figure 4.82).

\section{Number of Dwellings}

Site Area

Density

Access to amenities

Parking

Tenure

Average household income

Uses

\section{Existing Condition}

806 dwelling units

7.5ha (including parking)

107dph (dwellings per hectare)

Residents take advantage of surrounding neighbourhood connections and services such as public transportation, recreational, community, and health services.

290 \# parking spaces

(2.8 per unit)

Rented

$\$ 26,771$

Residential

\section{Proposed Revitalization}

906 dwelling units

7.5 ha (including parking and park)

$121 \mathrm{dph}$ (dwellings per hectare)

In addition; greater levels of commercial activity has been introduced on site, thereby activating the street plane and increasing connectivity to surrounding neighbourhoods by attracting both residents and nonresidents to these spaces.

250 \# parking spaces ( 3.6 per unit) Parking has been lowered as a move to reduce its carbon footprint while promoting alternatives such as auto share, cycling, and walking; modes of transportation which can flourish based on the sites' location.

Rented and private sale

$\$ 35,000$

Residential with ground level shops and commercial activity. 


\section{Building types \\ Building heights \\ Unit types \\ Communal open space}

Private/semi-private open space

Landscape and 'green'

Features

Energy saving measures

\section{Existing Condition}

Townhouses and apartments

Low, mid, and high-rise

3 bedroom units $\left(95 \mathrm{~m}^{2}\right)$, 5 bedroom units $\left(131 \mathrm{~m}^{2}\right)$, and 1 bedroom units $\left(64 \mathrm{~m}^{2}\right)$

Small, underutilized open Spaces

Balconies and small gardens

None present

None present

\section{Proposed Revitalization}

Townhouses and apartments

Low, mid, and high-rise

In addition; 1 bedroom units (60-75

$\left.\mathrm{m}^{2}\right), 2$ bedroom units $\left(100 \mathrm{~m}^{2}\right), 3$ bedroom units $\left(100-115 \mathrm{~m}^{2}\right)$, and 4 Bedroom units $\left(140 \mathrm{~m}^{2}\right)$

Proposal for a large, centrally located park (Vanauley Sq.), providing a space for diverse recreational activity for both residents and non-residents.

Balconies, small gardens, roof terraces, and allotment gardens

The landscape is now more of an integral part of the building design with the introduction of tree lined streets, green spaces, etc. Flat roofs are covered with grass to restore oxygen to the environment. Rain water run-off is collected and reused. Material from existing buildings to be removed will be reused in various ways for new construction (eg. Scrap brick/block ground into aggregate, gypsum used as a soil amendment, wood waste ground into mulch, etc.)

All rooms and circulatory systems have extensive access to natural daylight. Heavily glazed areas are coated with photovoltaic film which provides heating and cooling for the buildings.

Figure 4.82. Alexandra Park - Comparative Site Data 


\section{Summary}

Given all we have seen and experienced with past attempts at social housing design, present "discussion" should focus on a process of designing for 'integrated neighbourhoods' of mixed activity. Integration in this context speaks to the unifying elements necessary for creating housing developments which act as a continuation of the surrounding urban fabric rather than 'islands' separate from a broader community. This idea draws on five guiding principles (modes of integration) for the design or revitalization of social housing developments. Integration of movement, open spaces, physical structures, social integration, as well as integrated sustainable systems were the five categories used to examine the level of connectivity that characterizes Alexandra Park, Toronto, Canada.

A review of the 'integration of movement' indicated a deliberate separation between pedestrian and vehicular traffic that created 'super-blocks' of isolation. This was addressed by the reintroduction of Grange Avenue as a through road and allowing Napanee Crescent to support single lane traffic.

Regarding the 'integration of open spaces', an investigation of Alexandra Park revealed a series of relatively small, underutilized green spaces that did not lend well to activities of recreation and gathering. A response to this was the integration of a central activity core that could both support these uses as well as establish links between neighbouring communities.

The 'integration of physical structures' sought to create a fusion between the existing typologies on site (low, mid, high rise) as a means of establishing a 'design type' that extracts the positive elements of each. For instance, a fusion between a high rise and a townhouse combines the privacy and sense of ownership associated with the townhouse coupled with increased density of the high rise building typology.

An evaluation of Alexandra Park's 'social integration' identified a 100 percent R-G-I occupancy. Past failures have shown this trend leads to crime and drug-related activities. Social mixing (R-G-I and market rental) has entered regular practice to diversify the range of activities within a development, and provide an environment with positive role models where residents may gain inspiration and identify with alternate benchmarks for success. This social mixing has become an important part of Alexandra Park. 
New architecture should not proceed without considerable regard to sustainability. Integrated neighbourhoods are no different. In fact, these developments stand to benefit the most since issues of maintenance and operating costs are of critical importance. The physical design proposals for Alexandra Park are integrated with sustainable systems, such as energy generation and water collection, as a means of keeping these operating costs to a minimum.

Three building typologies were subsequently designed as a response to these five modes of integration. Then specifically addressed the issues which arose from investigating the current state of Alexandra Park's social housing development. 


\section{Data Analysis \&}

\section{Observations}

"I don't preach a social gospel; I preach the Gospel, period. The gospel of our Lord Jesus Christ is concerned for the whole person. When people were hungry, Jesus didn't say, "Now is that political or social?" He said, "I feed you." Because the good news to a hungry person is bread." 


\section{Data Analysis \& Observations}

\section{$-5-$}

The subject of social housing is undoubtedly one of the broadest issues facing our world today. It demands an understanding of a wide range of issues; specifically social, economic, cultural, spacial, architectural, legal, urban, and sustainable. It is also important to note that architecture, though a key component is merely one element of the creation of successful 'integrated neighbourhoods'.

Far too often we see designs that fail to consider the people who will eventually call these places home. As architects, if we are not prepared to fully understand and analyze this layer of social activity, what will result is a lack of sensitivity to critical social issues that determine the success, or failure of an integrated community.

This research has enabled me to realize that the 'architecture' of social housing is a rather delicate area of intervention that requires several layers of understanding, from tenant engagement to commercial integration to urban space planning. It also revealed the need to bring other disciplines on board during the preliminary design phase of an 'integrated neighbourhood' development or revitalization project. Urban planners, architects, social housing providers, anti-poverty groups, lawyers, sociologists, etc. should be included at a general design meeting. This became evident when I attended one such meeting where ideas were put forward on unusual trajectories that were guided and redirected by varying points of interpretation and analysis. It resulted in a conclusion that was integrative, thoroughly aware and considerate of all the issues. It was a result that could not have been obtained with the input of a single discipline.

As seen with the proposed revitalization of Alexandra Park presented here in, there is a limit to the areas in which architecture can ameliorate the issues of social housing. A set of guiding principles were developed to address these issues. The five 'modes of integration' were used as a basis to identify and suggest improvements/solutions for implementation.

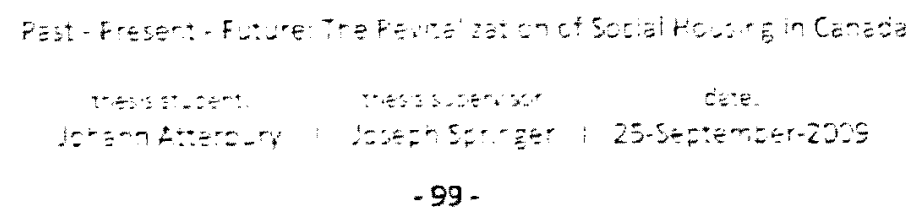


- Veterans Housing

o Programs for the

Fiscal Integrity

Private Rental Sector

Public Housing Program

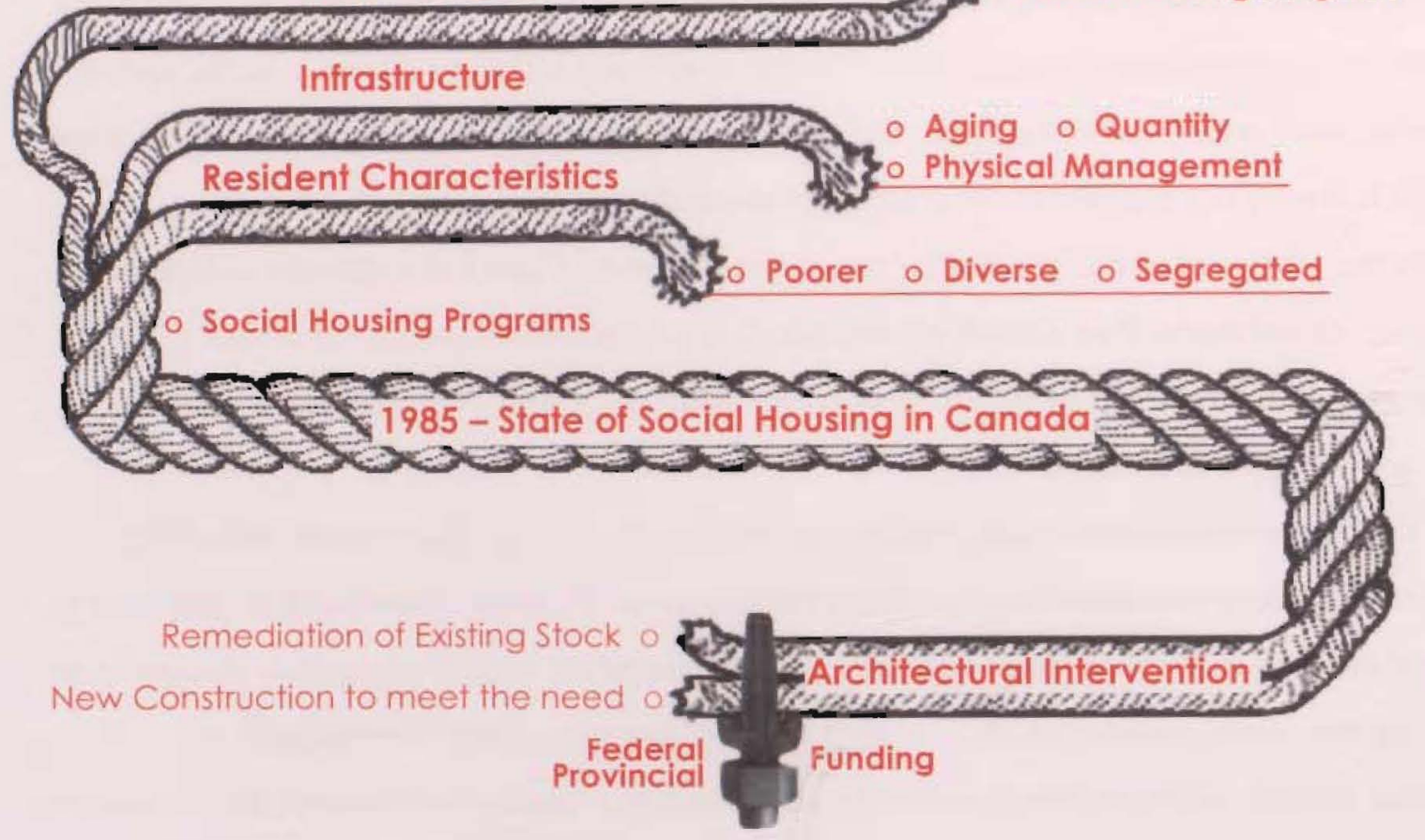

Figure 5.00. Conceptual Framework - the impact of architectural intervention on Canadian Social Housing Policy.

As we embrace an era of environmental awareness and carbon reduction, it is evident that we must continue to build on the successes of the recent past and establish a permanent fusion between social housing and sustainability for the future. With funding cuts and increased operating and maintenance costs for social housing providers, a renewed sense of commitment has to be established with senior levels of government (see figure 5.00). "It is our duty to use our skills, knowledge and resources to provide for those with the greatest need and the fewest options" (Sam Davis). 


\section{Toronto Community Housing Corporation: Tenant Engagement Meeting}

Tenant Engagement Consultations I Agency Consultations I Meeting Notes I Sept $19^{\text {th }}, 2008$

\section{Attendance:}

Ryerson University ..................................... Dr Joseph Springer, Johann Atterbury

Downsview Services to Seniors................ Joanne Jasper,

Streets to Homes...................................... Sharlene Cobain, Bonnie Wakely

St. Clair West Services for Seniors............ Kamal Singh, Janitha Joseph

Sistering ......................................................... Lara Almeida

Eastview Community Centre.................... Mohamed AD Mohamed

Neighbourhood Legal Services................. Anita Barnes

Houselink..................................................... Jackie Ronkine

* Meeting notes developed by Lancefield Morgan \& Heather Tillock - TCHC:

Can you give examples of initiatives/partnerships that have worked well with social service agencies that have involved TCHC tenants?

- Mental Health Pilot-Advisory committee

- Partnership with Eastview Community Centre -TCHC leveraging the experience of Eastview to further develop their relationship with the community

- Fife House -Support workers located in the building

- Houselink -Stressed the importance of communicating roles and identifying other support provided by other housing providers.

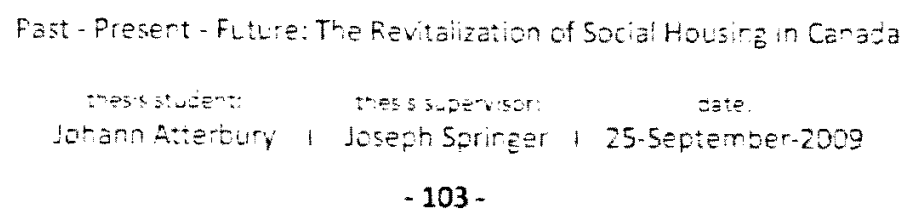


- Streets to Homes - Initiated a volunteer program from tenants/clients to provide informal supports and are looking to duplicate the model

- MAPP in TCHC building to address the lack of services use by Caribbean and Muslim communities -The MAPP was also an attempt to empower individuals to address challenges in life and play a decision-making role.

- It was noted that TCHC has been working on this issue for a long time and the current TPS isn't the first attempt at a system. It was also suggested that "one size will not fit all" as communities will form around ethnicity, language, interest.

Can you suggest some ways in which your organization could support the increased participation of tenants in the management of Toronto Community Housing?

- The need to balance between empowering tenants/clients and ensuring that they don't become dependent on the agency/staff. It's about building relationship in the community

- Recognizing that there are different ways of learning/doing/communicating with individuals and that day long mtgs won't work for some tenants (e.g. formerly homeless, youth)

- Recognize the importance of the role tenant leaders play outside of the formal system... "a lot happens after $5 \mathrm{pm}^{\prime \prime}$. More resources should be put into tenant leadership and training.

- Agencies can provide opportunities for residents/clients to develop their own skills (training and support)

- Agencies can provide education/info to tenants about housing/housing issues but need some feedback from TCHC around where they should be concentrate their efforts. What are the greatest needs, what is the best use of their times?

- Agencies are working on developing programming in partnership with TCHC, but that new partnerships need resources

- TCHC has differing roles (i.e. convener, catalyst, leaders, participant, partner) but that as partnerships are being developed TCHC is often expected to be a funder. Therefore, we are asked to pay for things/do things that fall under the responsibility of the school board, police, children's services etc. The suggestion is that agencies are already funded to provide services to targeted populations (i.e. youth) so why are new funds needed to working with those same

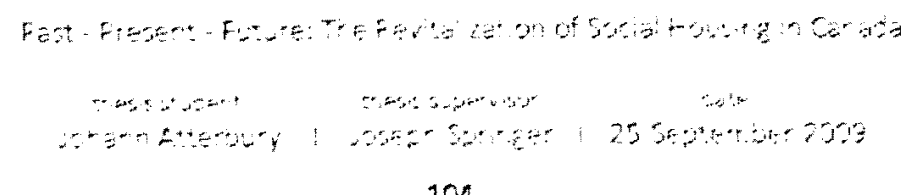


clients because they live in housing. - Participants agreed that TCHC isn't a funder, but in comparison to their own budgets, $\mathrm{TCHC}$ is massive and has the ability to put extra resources into projects. It was further noted that this is an issue that can be tackled jointly

- University systems can play a role in providing student resources to support partnerships, students can develop practical skills/research skill and agencies can increase the scope of their work within the partnership.

- There is also a need for real role clarity... who does what? Where is the size/scope of TCHC useful in leveraging resources versus a smaller agency

- Community health/wellness is a joint responsibility -TCHC for space/endorsements -Agencies for money for project/program support -Tenants for feedback and participation

Please describe some ways in which your organization supports the participation of TCHC tenants in citywide initiatives (i.e. 25 by 25, Mayor's Budget Consultations)?

\section{Group 1}

- Full-time community development co-ordinator focused on organizing residents/clients which results in member run campaigns

- A social issues committee that determines its own focus (ie.. ODSP levels, $\Pi C$ cost, etc.)

- Staff support (financial and physical) to attend events/mtgs/rallies

- It was noted that for some tenants being involved in campaigns wasn't a real option as they struggled with the basic life skills/survival issues. So for some residents the fist goal is to get them to care about themselves and work towards a broader engagement.

- Community education to overcome the stigma of mental health issues (as an example) as a way to over barriers of people participating.

- Social Action groups 


\section{Group 2}

- Training on legal issues

- Facilitate people's look at the larger picture -Asking different questions - What lessons have been learned that can inform future decision making -We need to use the research sector/resources better

- Need for wider involvement than just tenant representatives...solution focused

- Case managers who can be on-site in buildings -Advocacy and support roles can be delivered with some familiarity -Population we house needs "case management" -How do we put in place a structure that supports case management within the current TCHC environment?

Toronto Community Housing is committed to democratic participation of tenants. Describe methods of representation that would ensure the tenant voice is heard and representation is fair and transparent?

\section{Group 1}

- Participation at the Board level of the organization gets people involved in bigger topics/broader issues. -At some agencies, the numbers were $50 \%$ of board members were clients. -Having clients sit on hiring committees

- Alternatives to formal decision making structures...hands-on decision making "dotmocracy", consensus decision making

- It was strongly suggested that explaining process for decision making was vital for tenants to understand the full/true scope of what they can make a decision on.

- Tenants need tool to guide decision making, clarity around liabilities.

Open mitgs.

\section{Group 2}

- Old City Home Model -Good example of tenant empowered model -It was noted that a model already has been created, start there

- Tenants need support...especially tenants with special needs...tenant representatives can fill that role.

- Training needs to be consistent across the Board.

Past - Present - Future: The Revitalization of Social Housing in Canada 
- Broader awareness needed -Create opportunities for people to have their voices heard

- Recognize barriers to access/participation

- What does community interaction really mean? -In the Muslim community/Chinese community?

- The suggestion was made that there be a healing process for building/community where a tenant rep has been removed or there are issues.

Toronto Community Housing supports several issue based or thematic groups (ex. Anti-ableism committee or Hispanic Tenants Association). Describe ways to create opportunities for more of these groups to engage in a formal electoral system.

\section{Group 1}

- Where desired have staff support reflective of the group forming

- Develop leadership (formal/informal) among the group

- Support the group either with staff and/or money and/or with an advisory group.

Group 2

- Do we really need more groups that lack resources? -Huge resource implications to ask folks to join groups, but those groups don't have the resources. -(e.g. SOS, Voter Ed)

- Common Issues across communities -Revisit what we have now.... is it functional, what lessons have we learned, how do we build on what we have?

Past - Present - Future: The Revitalization of Social Housing in Canada 


\section{Interview - Ed Majchrowski - Toronto Community Housing}

Ed Majchrowski I Health Promotion Officer I Toronto Community Housing I Sept $26^{\text {th }}, 2008$

\section{Duties:}

- assessment of clients

- crisis prevention

- help better the lives of tenants

- promote community development and a sense of ownership

\section{General Points from the Meeting:}

- Toronto Community Housing (TCH) is the $3^{\text {rd }}$ largest social housing provider in the world

- tenants are housed on a rent geared to income policy (R-G-I)

- developments are (now) typically comprised of $60 \%$ market rent and $40 \%$ RGI

- in past developments $100 \%$ R-G-I promoted 'ghettoization of communities'

- a large portion of the population of Toronto are 'the working poor'

- 75,000-80,000 families are on the waiting list for housing assistance

- there are 63,000 social housing apartments in Toronto

- shortly before the year 2000 annual funding was downloaded from the provincial government to the municipal government.

- TCH received $\$ 75$ million from the federal government this year.

- They are currently lobbying to gain annual funding from the federal government. 


\section{Interview - Sam Davis - Affordable Housing Architect}

Principal - Sam Davis Architecture I Dean - College of Environ. Design - UC, Berkeley I Oct. 2008

"Sam Davis Architecture is a Berkeley, California firm with thirty-five years of housing experience. Working with institutions, market-rate and non-profit developers, and service providers, Sam Davis Architecture has designed housing for a wide range of people, many with special needs. The firm's projects include those for families, students, seniors, young people with HIV/AIDs, homeless youth, and homeless adults" (Sam Davis Architecture, 2008). It was while reading 'The Architecture of Affordable Housing', authored by Davis, that I drew inspiration and great respect for an individual who has devoted his life to the creation (by design) of housing for those with 'the most need and the fewest options'. I contacted Mr. Davis via email and was quite pleased to receive a rapid response from him. Mr. Davis is the newly appointed (interim) Dean of the College of Environmental Design, and a Professor of the Graduate School at the University of California at Berkeley. Following emails back and forth, I managed to pull together a virtual interview with Sam Davis, affordable housing architect. Following are results of the digital colloquy:

1.) Is it possible (for you) to reap sufficient profit from the design of social housing projects, or do you expose yourself to (what one would refer to as) higher profit projects in order to involve yourself in what would then become pro-bono work?

Affordable housing projects in the US generate fair fees. I never had to take other projects just to fund my work in this area. Oftentimes my clients cannot pay on a monthly basis as other types of clients might, so I may have to fund the work until they pay, but they always do. This is because their sources of funds are often either raised from donors or governmental and not within their control.

\footnotetext{
Past - Present - Future: The Revitalization of Social Housing in Canada

thesis student: thesis supervisor: date:

Johann Atterbury | Joseph Springer | 25-September-2009

-109 -
} 
2.) As an architect, the more we know about an issue, the better we are able to make strategic decisions and responses to multiple design challenges. As an affordable housing architect, how involved are you with local social housing organizations that deal with the distribution and ongoing operations of the existing social housing portfolio within your area?

I am not involved in organizations with whom I do not directly work. I am on various commissions and often do pro-bono advising to groups, however. I do work closely with my clients who are primarily either service providers or non-profit corporations. They have a track record of housing, whom they serve, and what works best for their constituency.

3.) Does your office work on other building types or do you strictly focus on Social/affordable Housing?

We work on other types of projects for social service providers such as clinics and drop-in centers.

4.) During the design phase of a social housing scheme, how much of a consideration is long-term building maintenance (and operation) for you? Looking at ideas such as energy and water collection methods (also day lighting rooms), the use of exterior (and interior) building (finishing) materials which don't require painting and so on? Thereby reducing annual maintenance and operating costs?

We always look to minimize operating costs since this is the type of funding for which there is no certainty. While energy conservation is important, we mostly focus on durability of materials and fixtures. Replacing cabinetry, for example, is very costly so providing high-quality initially is best. The same is true for exterior finishing and windows.

Past - Present - Future: The Revitalization of Social Housing in Canada 
5.) In terms of building typology, what are some of the typical characteristics of your social housing designs (specifically with regards to building height and densities)? Have you established a maximum height and density that you simply would not go beyond?

No; much depends on zoning and context, so we have no hard rules. There is much debate on how much should be placed on one site and no clear answers. The larger the number of units, the more you can afford a wide range of social services and amenities. The smaller the number, the more likely you will form a cohesive community.

6.) What is your hope for the future of Social Housing as it relates to architecture and architects? That we all get this message: What we build not only reflects, but also serves all of society, and not just those who can afford it. It is our duty to use our skills, knowledge and resources to provide for those with the greatest need and the fewest options.

Past - Present - Future: The Revitalization of Social Housing in Canada 


\section{References}

Atterbury, J. (2008). In Ryerson University. Department of Architectural Science. The role of the CMHC in revolutionizing housing types in postwar Canada. Unpublished.

Canada Mortgage and Housing Corporation (2008). History of CMHC.

Retrieved from the World Wide Web:

http://www.cmhc-schl.gc.ca/en/corp/about/hi/index.cfm

Canada Mortgage and Housing Corporation (2006). Canada Housing Observer 2006.

Canada Mortgage and Housing Corporation (1990). Evaluation of the Public Housing Program.

Canadian Council on Social Development (2008). Focus on Poverty in Canada, Defining the problem, Working strategies, Measuring success. Perception, Vol. 29, No. 3/4. Canadian Council on Social Development.

City of Toronto (2003). Toronto Report Card on Housing and Homelessness.

City of Toronto (2008). Mayor's Tower Renewal: Opportunities Book. Prepared for the City of Toronto by E.R.A. Architects and the University of Toronto.

CMHC and the building industry: Forty years of partnership (1989). In Carter T. (Ed.), . Winnipeg, Man.: Institute of Urban Studies.

Collins, S. (1996). In Ryerson Polytechnic University. School of Urban and Regional Planning. (Ed.), Urban redevelopment principles: a case study of Regent Park.

Davis, S. (1995). The architecture of affordable housing. Berkeley. University of California Press. 
Hulchanski, J. D. (2002). Housing Policy for Tomorrow's Cities. Canadian Policy Research Networks Inc.

Hulchanski, J. D. (2001). In University of Toronto. Centre for Urban and Community Studies. A Tale of Two Canadas: Homeowners Getting Richer, Renters Getting Poorer. Centre for Urban and Community Studies

Hulchanski, J. D. (1988). In University of British Columbia. School of Community and Regional Planning. (Ed.), Canada's housing and housing policy: an introduction. Vancouver, B.C. School of Community and Regional Planning, the University of British Columbia.

Inhabitat (2008). The Beautifully Unfolding Ocho Casas Housing Complex. Retrieved from the World Wide Web: http://www.inhabitat.com/2008/11/17/origami-inspired-social-housing/

Jones, P. (2005). Cabrini-Green: A Lesson in Public Housing. Retrieved from the World Wide Web: http://www2.uic.edu/ pjones7/cabrini.shtml

Mayor's Tower Renewal (2008). Pilot Sites. Retrieved from the World Wide Web: http://www.towerrenewal.ca/pilotSites.php

Ofis (2008). Retrieved from the World Wide Web: http://www.ofis-a.si/default.cfm

Petroski, H. (2006). Success through failure: the paradox of design. Princeton: Princeton University Press.

Sam Davis Architecture (2008). Retrieved from the World Wide Web: http://www.sdavisarchitecture.com/index.html

The geography of opportunity: race and housing choice in metropolitan America(2005). In De Souza Briggs, Xavier N. (Ed.), , Washington D.C.: Brookings Institution Press.

The Regent Park Collaborative Team, (2002). Regent Park Revitalization Study.

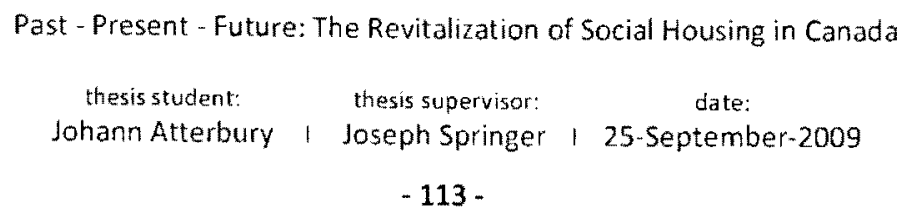


Toronto Community Housing (2008). Retrieved from the World Wide Web:

http://www.torontohousing.ca/

Toronto Community Housing (2007). Offering Memorandum.

Urban renewal: Alexandra Park, Toronto.(1969). In Menkes W. Z., Klein J. (Eds.), . S.I.: s.n.

Van Dyk, N. (1995). Financing Social Housing in Canada. Housing Policy Debate, Vol. 3, 15s. 4. Fannie Mae Foundation.

Wilkie, K. (2007). Building the Future: Public Policy Considerations for Affordable Housing in Canada. Canada West Foundation. 


\section{Social housing}

Affordable rental housing operated by co-operative or non-profit agencies, funded under comprehensive federal or provincial programs. Such programs usually provide operating subsidies and some mix of financing, financing guarantees, and/or capital grants, and assured affordability under 35 to 50-year agreements.

\section{Rent-geared to income (RGI)}

Most of the people who live in social housing pay a "rent-geared to-income" or RGI.

For these people, the Ontario government subsidizes the difference between 30 percent of their income and the rent they would have to pay in the private sector (market rent).

\section{Shelter system}

The shelter system refers to facilities that provide accommodation and support services to people who are homeless. In Toronto, the shelter system includes facilities administered by the City of Toronto and operated either by the City or a community based organization. These shelters are funded through a cost-share arrangement between the municipality and the provincial government. Abused women's shelters in

Toronto are $100 \%$ administered and funded by the Province.

\section{Homelessness}

The City of Toronto defines homelessness as a condition of people who live outside, stay in emergency shelters, spend most of their income on rent, or live in overcrowded, substandard conditions and are therefore at serious risk of becoming homeless.

\section{Supportive housing}

Past - Present - Future: The Revitalization of Social Housing in Canada 
Housing in which supports services are provided, either by the landlord or another agency. This involves staff who help residents to keep their housing or to live independently. Supports may include such things as help with daily activities (e.g. for elderly or disabled people), referrals to outside services and counseling, or occasional intervention or advice (e.g., for people with mental health disabilities).

\section{Let's Build}

Let's Build is a program established by the City of Toronto to help get new affordable housing built. It offers the services of a skilled team to assist in the planning and development process and a toolkit of incentives to increase the economic viability of affordable housing projects. These can include Cityowned land, waiver of development fees, tax incentives and one-time financial assistance from the City's \$11-million Capital Revolving Fund for Affordable Housing (CRF). Since launching in the spring of 2000 , Let's Build has helped put more that 650 affordable housing units in the pipeline.

From City of Toronto, 2003, Toronto Report Card on Housing and Homelessness, 2003, pp. 58-59. 